\title{
INWENDIGE NASAAL- EN LIQUIDA-VERBINDINGEN IN INDONESISCHE TALEN.
}

DOOR

\author{
J. GONDA.
}

Onlangs had ik gelegenheid, aan het einde van mijn opmerkingen over onomatopoeia, klank-symbolisme en woordvorming in een aantal Indonesische talen ${ }^{1}$ ), in het voorbijgaan er op te wijzen, dat een welbekend Indonesisch woordtype, nl. de tweesyllabige grondwoorden, die inwendig tussen beide vocalen explosief of $s$ met voorafgaande homorgane nasaal vertonen, een zekere overeenstemming blijkt te hebben met bepaalde woorden, ja groepen van woorden in Europese talen: in zoverre dat de nasaal vaak aan- en afwezig kan zijn in bijelkaar behorende nevenvormen: jav. kèmpi : kèpi, mal. sěmpit : sĕpit, du. pappen : pampen, fr. tabor : tambour. Nadat ik in een opstel van meer algemene aard ${ }^{2}$ ) de merkwaardige overeenkomst in uiterlijke gedaante tussen in Indonesische talen zeer gewone woordtypen enerzijds en bepaalde kategorieën van woorden in Indogermaanse talen anderzijds, zoals deze mij wil voorkomen, nader heb kunnen toelichten, stel ik mij voor thans enkele opmerkingen te maken, die bij beide genoemde verhandelingen aansluiten, en enkele woordvorm- en woordbouwverschijnselen op Indonesisch gebied wat meer in detail raken.

Wisseling van vormen met en zonder $n$ in verschillende Indonesische talen is bekend genoeg; ik volsta met enkele voorbeelden. Naast jav. sěpuh staat mad. sempò ${ }^{3}$ ), naast mal. taikis : soend. takis; zo mal. injak : jav. idak; tidong inkuy : daj. ikoh, mal. èkor etc. ; mak. bintun ,ster" : tag. bituwin, ib. bitun; daj. untek : tag. otak, bis. otok, jav. utak etc.; jav. lěmpit : boeg. lěpi; bim. raniki „,vlot” : mal. rakit; bim. baka ,wegjagen” : mak. boikk ${ }^{4}$ ); jav. werntis, tag. binti,

1) Some remarks on onomatopoeia, sound-symbolism and word-formation à propos of the theories of C. N. Maxwell, Tijdschr. Bat. Gen. 1940, p. 133 vlgg.

$\left.{ }^{2}\right)$ Opmerkingen over de toepassing van de comparatieve methode op de Indonesische talen, voornamelijk in verband met hun woordstructuur, Bijdr. Kon. Inst., 99, pp. 397 vlgg.

3) Meer bij Kiliaan, Madoereesche Spraakkunst, I, § 53, p. 48.

4) Jonker, Bimaneesche Spraakkunst, p. 51 geeft meer. 
daj. buntis : bis. bitiis, mak. bitisi, mal. bĕtis, mad. bĕttis; mak. lempan, mal. limpa : soend. kalilipa; jav. mutah : mal. muntah; mal. mimpi : ojav. bat. ipi; mal. ӗmpat : tag. bis. e.a. apat, tbat. opat etc.; jav. mal. měntah : ttb. etc. mata; mal. tunjuk : bar. tuju. Het is volstrekt niet zo, dat de nasaal steeds in dezelfde taal wel, in een andere niet optreedt. Dezelfde wisseling in één taal vinden we bv. in ojav. idĕr : indĕr, njav. rasuk : ranisuk, bloson : blonison, krosi : kronsi, ritik $^{2}$ : rintik, laka : lanka; mal. tijak : tinjak, sěpit : sěmpit, tapai : tampai; kucup: kuncup. In het Dajaks komt voor - $k$ - tamelijk regelmatig $\dot{n}$ : baku: baikku, ,gestollt"1). Er kan dialektverschil zijn: ocun : oncun ,vergif” op Mentawei ${ }^{2}$ ), waar $n j$ Noordelijk is : lanjagan „zeilschip" (mal. layaran); in verschillende dialekten van het Bare'e kejo : kenjo „mank”, zo ook op Madoera ${ }^{3}$ ). Met semantische differentiatie vinden we de wisseling $\left.{ }^{4}\right)$ : mal. jabatan ,ambt, betrekking” : jambatan ,steiger, brug”; bar. babari ,uitspreiden”; bambari „nieuws".

Aan de wisseling binnen eenzelfde taal is door den schrijver van meer dan een grammatika aandacht besteed, hoewel er ook verscheiden auteurs zijn geweest, die het verschijnsel tot die vele punten van taalbeschrijving schijnen te hebben gerekend, die de moeite van het vermelden niet waard zijn $^{5}$ ). Poensen ${ }^{6}$ ) en Kiliaan ${ }^{7}$ ) wezen op Javaanse voorbeelden als munsuh : musuh, sambĕn : saběn, Spat ${ }^{8}$ ) gaf een lijstje voor het Maleis; Adriani ${ }^{9}$ ) gaf Sangirese voorbeelden als kibu : kimbu ,stuit van de vogel”, katupa : katumpin „e.s.v. rijstspijs", Kiliaan ${ }^{10}$ ) Madoerese, Esser ${ }^{11}$ ) Morische enz.

Het lijkt mij overbodig bij dit frequente woordtype - volgens Dempwolff ${ }^{12}$ ) behoort $\pm 20 \%$ van de door hem geconstrueerde oer-IN.

1) Hardeland, Versuch einer Grammatik der Daj. Spr., p. 9.

2) Adriani, Spraakk. schets der Mentawei-eilanden, Bijdr. 84, p. 24 en 25. Vgl. ibidem, p. 13: N.-Mentaway heeft een neiging tot „praenasaleren” die Z.M. niet vertoont, bv. ook enket, „kleven” : eket. Voorts p. 19 boven en elders.

3) Bijzonderheden bij Kiliaan, o.c., I, p. 8.

4) Over tubuh : tumbuh en derg.: Brandstetter, Prodromus, p. 19; een algemeene opmerking bij Dempwolff, Die Lautentsprechungen der IN. Lippenlaute, p. $29 . \quad 5$ ) In de volgende opsomming is niet naar volledigheid gestreefd.

6) Poensen, Grammatica der Javaansche Taal, § 71.

7) Kiliaan, Javaansche Spraakkunst, p. 70 A. 1.

8) Spat, Maleische Taal ${ }^{4}$, p. 24.

9) Adriani, Sangireesche Spraakkunst, p. 28.

10) Kiliaan, Mad. Spr. $\S 53$, p. 48.

11) Esser, Klank- en vormleer van het Morisch, I, p. 18.

12) Dempwolff, Vergleichende Lautlehre des austronesischen Wortschatzes (1937), II, p. 7. 
woorden er toe -, dat, door Brandstetter ${ }^{1}$ ) het lintah-type genoemd, met de taptap-woorden volgens hem die groep van IN. woorden vormt, die tussen de beide vocalen meer dan één consonant hebben, uitvoerig en systematisch melding te maken van dat wat er in de loop der jaren over is opgemerkt. Voor verklaringspogingen moet ik evenwel een uitzondering maken, van het overige komt een en ander beneden nog ter sprake ${ }^{2}$ ).

Fokker geeft in zijn werkje „Malay Phonetics” slechts enkele opmerkingen: de $\tilde{n}$ in panjan en dergelijke ,has the same function as $n$ before $d$ and $t, \dot{n}$ before $g$ and $k, m$ before $b$ and $p$, i.e. smoothing the joining of a preceding sound with a following one”. „Malay $n$ immediately followed by $t$ or $d \ldots$ is often omissible", en staat er verder niet bij stil ${ }^{3}$ ).

Enkele auteurs hebben klaarblijkelijk de overtuiging gehad, dat de groep IN. woorden met inlautend meer dan één consonant, gezien de opvallende frequentie van het lanit- en mata-type, ons voor een probleem stelt. Geeft nu het taptap- of butbut-type zowel statisch als historisch - al zou ook hierover nog veel te zeggen zijn - minder moeilijkheden, de lintah-groep schijnt niet zo eenvoudig te zijn. Hoe moeten we ons de verhouding voorstellen tussen nasaal + occlusiva tegenover de enkele occlusiva in parallelvormen of verwante woorden in dezelfde of in andere talen? Is deze verhouding steeds eender? Is het aantoonbaar dat dit type, vergeleken met de mata- en lanit-woorden, jonger is? Zo ja, hoe is het dan ontstaan? Heeft een vorm met inwendige nasalering naast die zonder dezelve oorspronkelijk een andere betekenis gehad? Zo ja, wat was dan de functie van de nasaal? etc. Is er verband met het bekende aanvangsnasaleringsverschijnsel : mal. puñut : měmuñut?

1) Brandstetter, Die Lauterscheinungen in den indonesischen Sprachen (1915), $\S 195$.

2) Men kan in het lintah-type globaal een zekere indeling maken en daarbij van een recente materiaal-verzameling van Dempwolff gebruik maken (Dempwolff, o.c., I, pp. 96-109), die, telkens afzonderlijk nemende de gevallen waarin betekenisovereenkomst en die waarin betekenisverschil bestaat, eerst de nasaal + media-verbindingen (en dan wel iedere klasse, labialen etc. afzonderlijk) verzamelt, dan de nasaal + tenuis-verbindingen, dan de gevallen met fakultatieve nasale „Zuwachs”. Hij streeft hierbij andere doeleinden na dan wij; en het heeft voor ons geen nut, deze systematische indeling over te nemen. Zou iemand echter een volledige materiaal-verzameling van het verschijnsel der inwendige nasalering in een of meer Indonesische talen wensen te geven en deze naar de voorkomende gevallen ordenen, dan zou hij in Dempwolff's overzicht een goed vergelijkingsobject met het geconstrueerde Oerindonesisch hebben:

3) A. A. Fokker, Malay Phonetics, Diss. Leiden 1895, pp. 42; 53. 
Brandstetter sprak in zijn Lauterscheinungen eerst ${ }^{1}$ ) over het tot het UrIndon. (Original IN.) behorende lintah-type: ,in almost all the IN. languages the combination of nasal + cognate explosive is permitted medially", dan ${ }^{2}$ ) over die welke hij niet voor oer-IN. houdt: „In very many cases in IN. languages there appears before a consonant a nasal, which is wanting in other IN. languages, and which we cannot ascribe to Original IN. either. The word for „brain” in some of the languages is utěk, in others untěk; ,to pursue" is usir and unsir in Old Javanese. Now there are in the IN. languages a great number of very commonly used prefixes and suffixes containing nasals, and it is from these that the nasal has forced its way into the interior of the word-base ${ }^{3}$ ) by means of the principle of the repetition of sounds. From the OJav. word-base usir, for example, comes the active anusir or manusir, and from this $a \dot{n}$ - or main- the $\dot{n}$ has been projected into the variant from unsir of the word-base".

Adriani verdedigde een andere opvatting, die evenwel die van Brandstetter niet behoeft uit te sluiten ${ }^{4}$ ). Volgens hem is de nasalering in het woord - lastig is, dat hij dit verschijnsel en de aanvangsnasalering niet in naam (,prenasaleering”) onderscheidt ${ }^{5}$ ) - van andere aard dan die ,van den beginner, klinker (hamzah) of medeklinker, van geluids- en bewegingswoorden, die intensiefmakende kracht heeft", derhalve van andere aard dan het bekende zg. nasaleringsverschijnsel: bunuh: membunuh. „Prenasaleering is zeer gebruikelijk; ze heeft soms enkel fonetische beteekenis, dikwijls echter ook spraakkunstige; ... (dergelijke) vormen, hetzij aan de beginsyllabe of aan eene niet-aanvangslettergreep geprenasaleerd, verschillen in beteekenis meestal van hunne niet-geprenasaleerde nevenvormen. Men kan deze laatste dan als grondwoorden van de eerste beschouwen. ... Voor een deel is (deze soort prenasaleering) te verklaren door den invloed van een vroegeren nasalen sluiter. De boven gegeven voorbeelden rangkeani, ampe ..., teruggebracht tot de vormen rangkean, ampin..., waartoe de nevenvormen het recht geven, vertoonen alle een nasalen sluiter; bantjoe „mand”, mal. basoeng..., inda

1) $\S 195$ (Engelse editie: Brandstetter-Blagden, An Introduction to Indonesian linguistics, p. 298).

2) Ibidem, § 234, Introduction, pp. 309 vlg.

3) D.w.z. grondwoord.

4) Adriani, Spraakkunst der Bare'e-taal, uitgegeven door Esser, Verh. Bat. Gen. 70 (1931).

5) Ik stel voor aanvangs- en inwendige (prae)nasalering te bezigen in de woordvormingsleer, de term praenasalering in de klankleer. 
„schuld”, tag. hiram ... kunnen op dezelfde wijze verklaard worden ....".

Dempwolff heeft zich meer dan eens over het woordtype uitgelaten. In $1920^{1}$ ) betoogde hij, terecht onderscheidend tussen „Nasalverbindung des Anlauts” (Pränasalierung) en „Nasalverbindung” (inwendige nasalering), dat waar de eerste ,mit einer funktionellen Abänderung der Wortbedeutung verbunden" is, de tweede daarmee niet gepaard gaat. In $1937^{2}$ ) merkte hij op: „An der Grenze von Lautvorgang und Lauterscheinung steht das Auftreten von nasalem Zuwachs bei inlautenden Verschlußlauten... Auch hier ist eine etwaige psychologische Funktion unbekannt”. Reeds uit de term ,nasaler Zuwachs", die hij meermalen bezigt ${ }^{3}$ ), blijkt, dat hij een genasaleerde occlusiva im Inlaut als secundair beschouwt. Het karakter van deze „Zuwachs" duidt hij nader aan met „fakultativ" ${ }^{4}$ ). Hij concludeert ${ }^{5}$ ), „daß die Lauterscheinung des nasalen $\mathrm{Zu}$ wachses beim Inlaut ursprünglich ein Laut vorgang gewesen ist, ebenso wie beim Anlaut, da $B$ aber der erste früh erstarrt ist, während der letzte lebendig blieb. Man darf wohl vermuten, da $\beta$ es sich beim nasalen Zuwachs des Inlauts um ein Infix gehandelt hat, aber dessen ursprünglichen Lautbestand und seine grammatische Funktion sind nicht aufzuklären". Intussen had hij een afzonderlijke verhandeling gewijd aan het ontstaan van nasalen en nasaalverbindingen in het Ngadjoe-Dajak ${ }^{6}$ ), waarin hij binnen het kader van deze taal het verschijnsel onderzocht en in wording trachtte te verklaren, en de resultaten op grond van de IN. taalvergelijking historisch poogde te ordenen. Als oudste laag, daterend uit de ,graue Vorzeit der austronesischen Ursprache", beschouwt hij die nasaalverbindingen, die „durch den Zusammentritt zweier Wurzelwörter zu einem Stammwort entstanden sind" ${ }^{7}$ ); een jongere groep zijn volgens hem die, welke door infigering van een (hypothetische) $m$ zijn ontstaan, bv. ${ }^{8}$ ) ,zu sipa „der Betelbissen” simpa neben mañipa „Betel kauen” ${ }^{\text {9); }}$

1) Dempwolff, Die Lautentsprechungen der indonesischen Lippenlaute in einigen anderen austronesischen Südseesprachen, Beihefte zur Zs. f. Eingeborenen-Sprachen, II, pp. 27 vlgg.

2) Dempwolff, Vergl. Lautlehre... II, p. 8.

3) Zie bv. ook ibid. I, p. 31 .

4) Ibidem, p. 103.

5) Ibidem, I, p. 109.

6) Dempwolff, in Zs. f. Eingeborenen-Sprachen, 13 (1922-3), pp. 161 vlgg.

7) Zie aldaar p. 203.

8) Aldaar, p. 180.

9) Vgl. Hardeland, o.c. p. 23 boven. Zie ook Brandstetter, Prodromus, p. 19. 
deze zouden in een oud stadium van het Dajaks zijn gevormd; het moet ${ }^{1}$ ) tijdens de Hindoe-invloed op Borneo nog een levend procédé geweest zijn. Door daarop volgende Maleise invloed op het Dajaks zou de $m$-infigering zijn teruggedrongen, het werd ,ein mehr mechanisierter Lautvorgang ... der sowohl seine frühere intensive als auch seine übernommene aktivische Bedeutung fast verloren hat"; in deze periode valt ook de dissimilatie van de nasaalverbindingen ${ }^{2}$ ), d.w.z. „Reduktion der Nasalverbindungen des Anlauts zu reinen Nasalen durch fernwirkende, rückschreitende Dissimilation vor Nasalen und Nasalverbindungen des Inlauts" ${ }^{3}$ ).

Het wil mij voorkomen, dat de opmerkingen van deze drie beoefenaren der Indonesische Taalwetenschap wel tot enige discussie aanleiding kunnen geven ${ }^{4}$ ). Voorop dient daarbij te staan, dat een volledige verklaring van de verschijnselen van inwendige nasalering ${ }^{5}$ ), gezien onze zeer onvolledige kennis van vele Indonesische talen, onmogelijk is. Hier bedoel ik niet alleen onvolledige kennis van het verleden, van de geschiedenis der vormen die in aanmerking komen,

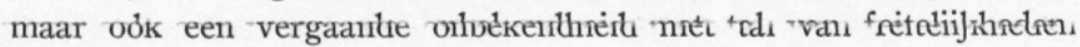
betreffende de talen in hun huidige stadium, die een verklaring bemoeilijkt of belemmert. En afgezien hiervan brengt de studie van een verschijnsel als het onderhavige, dat zowel op fonetisch- als op woordvormingsterrein ligt en dat het product van verschillende samenwerkende of elkaar kruisende factoren kan zijn, bijzondere moeilijkheden met zich mee. En dit wel niet alleen op Indonesisch gebied.

1) p. 204.

2) p. 205 .

3) p. 195 .

4) Het betoog van Jonker, Bimaneesche Spraakkunst, p. 16, die argumenten bijbrengt om ,het ontstaan van een nasalen voorslag" uit het voorkomen en later gedeeltelijk verloren gaan van met nasaal eindigende praefixen, kan hier buiten beschouwing blijven, daar het de inwendige nasalering niet raakt. In dit verband zij nog herinnerd aan de opmerkingen van Roorda, Javaansche Grammatica, § 84: na voorbeelden als cancut „zijn kleed opschorten”, dandan „zich gereed maken”, liñlà் = lélà < port. leilão „publieke verkooping”, waniwa = wawa „gloeiende kool” e.a. te hebben aangehaald, zegt hij „men ziet het, in al deze woorden heeft het (het optreden van de nasaal) plaats tusschen twee gelijke letters; hierin moet dus de oorzaak liggen; ofschoon ik gaarne bekennen wil, dat ik die oorzaak niet beseffen noch verklaren kan". Maar in rumanisa = rumasa ,gevoelen" e.a. die Roorda in het begin van dezelfde paragraaf citeert zijn de omstandigheden anders.

5) Ter vereenvoudiging van de probleemstelling en de verkenning van de wegen van onderzoek kan men, dunkt mij, de aanvangsnasalering voorlopig afzonderlijk bezien, al mag men zeker niet nalaten beide verschijnselen in onderling verband te beschouwen. 
Ook elders is - ik kom er nog op terug - de zg. ,epenthesis van een nasaal" bekend, en ook daar is niet alles duidelijk. Reeds ongeveer 30 jaar geleden schreef Schuchardt ${ }^{1}$ ): „Seit langer Zeit hege ich die Überzeugung daß eine vergleichende Lautgeschichte die außerhalb der gewöhnlichen Sprachvergleichung steht, oder m.a. Worten sich nicht auf die Verwandtschaft zwischen den Sprachen stützt, auch für die Forschung auf den Einzelgebieten nicht nur nützlich, sondern vielfach sogar notwendig sich erweist... das Wesen des Nasaleinschubs läßt sich innerhalb enger Grenzen nicht wirklich ergründen". Meer dan een toetsen van de te berde gebrachte verklaringspogingen en een verkenning van enige andere wegen, die misschien een eindweegs tot verhelderd inzicht kunnen voeren, kan daarom het volgende niet geven.

Dat de verklaring van Adriani niet in alle gevallen kan opgaan, is ook reeds implicite erkend door Esser, die zijn leermeester op dit punt volgt ${ }^{2}$ ): „dikwijls is een consonant geprenasaleerd door den invloed van een elders in 't woord voorkomende nasaal", maar voor deze groep als $\beta$ laat hij onder $\alpha$ voorafgaan ,zeer frequente wisseling" in gevallen als mori unto ,hersenen": mal. utak, waar van een elders in het woord optredende nasaal geen sprake kan zijn. Dat Adriani zelf zijn gedachten ook in andere richting heeft laten gaan, blijkt wel uit een opmerking in zijn dissertatie ${ }^{3}$ ), waarin hij constateert: ,het verschijnsel (dezer nasalering) is niets anders dan 't los sluiten van een open lettergreep" ${ }^{4}$ ). Dan blijft echter de oorsprong of oorzaak onverklaard, en ook het feit dat het verschijnsel slechts in een antal gevallen en niet steeds voorkomt, elders weer facultatief is. Individuele en dialektische uitspraakgewoonten van deze aard mag men echter a priori niet uitsluiten.

Wat de hier boven in extenso medegedeelde verklaringspoging van Brandstetter betreft, er zouden zeker gegevens zijn aan te halen, die er voor pleiten. Zijn de stamwoorden in het Dajaks in het algemeen onveranderlijk, leert Hardeland ${ }^{5}$ ), ,,als einzige Ausnahme... schieben alle die Wörter, deren 2. Sylbe mit einem $j$ beginnt, wenn die Präfixe $m$, ma oder pam (seltner $h$ ) davor treten, ein $n$ in das Wort, vor das

1) Schuchardt, in Zs. für Roman. Phil. 35 (1911), p. 82.

2) Esser, Klank- en vormleer van het Morisch I, Verh. Bat. Gen. 67, 3, p. 18 vlg.

3) Adriani, Sangireesche Spraakkunst, p. 29.

4) Vgl. daarbij ook Jespersen, Lehrbuch der Phonetik2, p. 57; H. Logeman, in Englische Studien, 34, p. 252.

5) Hardeland, Gramm., p. 22. 
$i$..., z.B. ujah „Salz”: munjah ,salzen”, pamunjah, doch auch pujah, paujah ...; sajat „eine Schnitte” ... manjanjat ,in Stücke schneiden”, panjanjat, maar pasajat...”, vgl. ook dipah ,jenseits”: hanimpah ,übersetzen" "1). En ook elders is er beïnvloeding of samenhang tussen verschillende praenasaleringen in één woord aanwezig ${ }^{2}$ ).

Maar er zijn te veel uitzonderingen en gevallen die zich anders gedragen, en al deze verklaren door later ingetreden dissimilatie gaat niet aan; zo kan men alles verklaren. En bovendien zijn er tal van woorden bij betrokken, die nooit aanvangsnasalering kennen ${ }^{3}$ ). Moet men die dan door analogie uitleggen? Hoe staat het dan met de gevallen, waarin de nasaal op grond van taalhistorische en taalvergelijkende gegevens jonger schijnt te zijn in woorden die geen aanvangsnasalering ondergaan? Een ander bezwaar tegen Brandstetter's opvatting lijkt mij het bestaan van woorden die in het midden niet nasaal + consonant, maar een andere consonant + consonant hebben. Op een grote groep kom ik straks te spreken, hier wijs ik slechts op jav. (lit.) lastri "nacht” naast latri < skt. rātrī, ojav. listu ,schoonheid" naast litu(hayu), jav. upĕkti (lit.) „cijns" naast upěti < skt. utpatti-, jav. cipta ,gedachte etc.” naast cita < skt. citta-, mal. těptibar „geitenmelker" naast tětibar, soend. boktěl < ned. wortel, tbat. besten „,vesting”: mal. benten, gevallen als kbat. gestun „opvlammen”: tutun „,branden”, waarin geen etymologische identiteit van gehele woorden bestaat, buiten beschouwing gelaten. Hier is niet alleen de redenering van Brandstetter onmogelijk, doch in sommige gevallen een andere weg tot verklaring terstond de aangewezene, zoals bv. in jav. wěkdal „vastgestelde tijd" = wěktu naar analogie van wědal ,opkomst van de maan enz.": wětu. En al behoeven deze gevallen in wezen niet identiek te zijn met het verschijnsel der ,bijkomende inwendige nasaal", men mag ze toch niet a priori negeren ${ }^{4}$ ).

Komen we thans tot Dempwolff's artikel over de nasaalverbindingen in het Ngadjoe-Dajak, dat op een, helaas tot één taal beperkte, uitgebreide materiaalverzameling en -studie opgebouwd is. Behalve

1) Ibidem, p. 32 .

2) Zie bv. Esser, o.c., § 28.

3) Trouwens, op de reeds boven geciteerde plaats in zijn Prodromus (p. 19), waar hij voor mal. tumbuh naar het Dajaks verwijst (,nun müssen im Daj. Wurzeln mit Inlaut $y \ldots$ vor dieses $y$ ein $n$ einschieben, wenn sie zu Verben werden sollen”), voegt hij toe „misslicher sieht die Sache bei mal. utak „Hirn”: day. untek aus".

4) Men kan uiteraard nog verder gaan en ook gevallen als njav. (lit.) musțika "muis" < skt. ojav. minsika- bestuderen. 
de boven aangehaalde verklaring geeft hij nog enkele andere - voor andere gevallen. Meer dan eens, betoogt hij $^{1}$ ), is het ontstaan van „inwendige nasalering” terug te brengen tot „Zusammensetzung von zwei Wurzelwörter", waarvan een speciaal geval (ik zou dit geen samenstelling noemen) de iteratie is van het type panpan $>$ pampan. Hiertegen is niets in te brengen: in dit geval blijft in vele talen ook een andere inwendige combinatie bestaan: ojav. toktok, tbat. kipkip, waarmee ojav. taintan op één lijn staat. Men kan deze gevallen ook onder het taptap-type brengen en het wil mij zelfs toeschijnen, dat vele in het taalsysteem daarmede ook een grotere verbondenheid bezitten dan met het lintah-type. In hoeverre andere in oorsprong of in uiterlijk identieke gevallen (als bv. mal. pampan, tg. tbat. dïndin, mal. dindin) in het taalsysteem, waarin zij thuis behoren geheel met mal. toǹton் en derg. op één lijn staan, laat ik in het midden. Eveneens of i e d e r tantan-woord ook werkelijk in oorsprong een iteratie is en of dit steeds aan te tonen is. Is bv. ng.day. tantan ,der Gipfel” werkelijk een verdubbeld $\tan$,richting" ? ${ }^{2}$ ) In sterkere mate meen ik twijfel te moeten koesteren ten aanzien van meer dan een woordverklaring door middel van wortelsamenstelling van het type: ng.dj. lantai ,der Flur (eines Bootes)” < *lam „Inneres” (ng.d. dalam ,in”, ulam ,mundvoll”) + *tai ,hinüberschreiten” (ngd. tatean „der Steg”, matei „sterben” wörtlich „hinübergehen - ins Jenseits”). In menig geval zijn de woorden waarop men dergelijke combinaties baseert en deze combinaties zelf over meer dan een IN. taal verbreid, en dan moet men met compositie reeds in de oertaal rekening houden, en bij studie van het verschijnsel binnen het kader van één taal van de klankverbinding als gegeven uitgaan ${ }^{3}$ ); maar dan kan de oorsprong ervan niet in discussie komen; in vele andere gevallen moet men met te veel onzekere elementen werken en blijft het combineren van niet meer dan (soms vage) mogelijkheden ${ }^{4}$ ).

Meer schijnt er mij te zeggen naar aanleiding van de verklaring van vele gevallen van inw. nas. uit het infix $-u m$-, dat, tot $-m$ - geworden, voor niet-labialen tot de resp. homorgane nasaal zou zijn ontwikkeld. Deze verklaring gaat, als is ze door Dempwolff uitge-

1) Dempwolff, o.c., p. 178 sub 2.

2) Dempwolff, o.c., p. 138, sub 2 b.

3) Zoals Dempwolff in zijn Verg. Lautl. III, p. 92 zelf ook doet: lantaj als Oeraustron. vorm. Zie ook reeds zijn „Nasale im Ngadju”, p. 203, sub I.

4) In gevallen als bar. gingiri < giringiri ,koperen rinkelbelletje” (Adriani, Bare'e-Ned. Wdb., s.v.) kan men de $\dot{n}$ mede als rest van een complete verdubbeling (<mak. mal. girin $\left.{ }^{2}\right)$ laten gelden.

D1. 101. 
werkt $^{1}$ ), terug op Brandes, die $^{2}$ ), nadat Hardeland ${ }^{3}$ ) op de z.i. onregelmatige vormen als sipa „betelpruim” (cp. mal. sěpah): mainipa ,betel kauwen”, waarnaast simpa, gewezen had, opmerkte, dat dergelijke gevallen als verstarde met -um-geinfigeerde vormen zouden zijn te beschouwen, die ,verklaard (zouden) kunnen worden als ontstaan tengevolge van een eigenaardige wijze van samentrekking, die een nader onderzoek zeer waard zou zijn". Aan deze verklaring uitbreiding gevend, stelde Dempwolff de hypothese op, dat deze $m$ ook ,in erweiterte Stammwörter, in erweiterte Wurzelwörter und in zusammengesetzte Präfixe unter Bildung der Nasalverbindungen $m p$, $n t, n^{\prime} t^{\prime} \ldots$ und $\dot{n} k$ eingedrungen ist" $\left.{ }^{4}\right)$.

Het wil mij voorkomen, dat men zal moeten toegeven, dat deze theorie in een aantal gevallen het juiste kan hebben getroffen, niet alleen voor het Ngadjoe-Dajak, doch ook meer in het algemeen. Men mag, dunkt mij, ngd. kuman ,eten” en mal. makan etc. vergelijkende, niet aarzelen het eerste in $k a n+-u m$ - te analyseren, het tweede in $k a n+m a-$, gegeven de omstandigheid, dat er parallelle gevallen zijn en dat kan ook elders terug te vinden is ${ }^{5}$ ). Dat er omstandigheden kunnen optreden, waaronder dit $-u m->-m$-, mag men a priori niet ontkennen, doch men zou willen zien toegelicht, waarom *musipa (-um- zou dan uit $m u$ - zijn ontstaan) $>{ }^{*} \operatorname{simupa}>\operatorname{simpa}$ ontwikkeld is. Dat dergelijke ontwikkelingen elders wel eens plaats hebben is niet bewijzend; men heeft het recht hier een geformuleerde regel te eisen. $\mathrm{Er}$ is geen noodzaak de $\operatorname{sim} p a$-woorden met behulp van een nasaal-infix dat uit $-u m$ - ontstaan is te verklaren ${ }^{6}$ ); afgezien van de gevallen, waarin het geven van een verklaring buiten ons kader valt doordat de nas. + cons.-combinatie reeds oerindonesisch is, zijn er andere wegen, waarlangs ze ontstaan kan zijn. In de eerste plaats kan schijn ook hier bedriegen. Al wat er in een woord, vergeleken met blijkbare verwanten, als formatief element uitziet behoeft dat in oorsprong niet te wezen. Maken ned. zenuw tgr. zeen, eng. sinew

1) Nasale im Ngadju, pp. 179 vlg., 191 vlg.

2) Brandes, Bijdrage tot de vergelijkende klankleer, (1884), p. 169.

3) Hardeland, Versuch einer Grammatik der Dajackschen Sprache, p. 57.

4) Ter bekorting verwijs ik naar zijn publicatie, p. 180 vgll. voor voorbeelden. Enkele komen nog ter sprake.

5) Zo ook Brandstetter, Wurzel und Wort, § 86, II.

6) Een argument er vóór (nl. dat de $m$ een nasaalinfix met grammatikale betekenis zou zijn) kan men echter ontlenen aan wat Hardeland, o.c., p. 23 zegt : „Einige Wörter, deren 2. Sylbe mit $p$ beginnt, schieben statt des Präfixes ein $m$ in das Wort vor das $p$; z.B. sipet „Blasrohr": simpet (auch manjipet) „durch ein B. schiessen"”. 
tgr. onoors sin, geluw en eng. yellow tgr. geel, ned. schaduw tgr. eng. shade, ned. zwaluw tgr. du. Schwalbe niet de indruk een element $-u w-$, een suffix $-u w-$ te bevatten? Toch is dit -uw, zelfs al zou het taalgevoel dit nu als zodanig opvatten, in oorsprong geen suffix. Deze woorden zijn doubletten ontstaan uit verschillende casus-vormen, waarin $u$ of $w$ na consonant een verschillende ontwikkeling doormaakte, al naar hij in Auslaut stond (zo nom. sing. ${ }^{*}$ gelw- $>{ }^{*}$ w.germ. ${ }^{*}$ gè $l o>$ mndl. ghêlo, gēls $>$ ned. geel) of in Inlaut (gen. sing. *gelw-es $>{ }^{*}$ geluw-es $>$ geluw). Ook in historieloze talen moet men met, mutatis mutandis, dergelijke ontwikkelingen rekening houden. En ten tweede: $\mathrm{al}$ is in een deel der woorden die het bewuste element bevatten dit terecht te verklaren op een wijze als door Brandes en Dempwolff is voorgesteld, dan wil dit nog niet zeggen, dat alle, of zelfs dat de meeste, gevallen behoren tot een oude periode, waarin het ,infix” met een eigen wel te definiëren betekenis, die Dempwolff ${ }^{1}$ ) overigens in het midden laat, zou zijn voorgekomen. Langs analogische weg, door kruising (blending) etc. $\mathrm{k} \mathrm{unnen}$ onder invloed van een paar woorden, waarin $-m$ - of andere nasaal $<-u m$ - ontstaan is, verscheidene andere woorden met inw. nas. zijn opgekomen. Dat dergelijke procédés werkzaam zijn, weet men reeds lang, op welke schaal zij veelal werken heeft ons de dialektgeografie recht duidelijk gemaakt. En dan komt er bij, dat de analogie ook kan zijn uitgegaan van die gevallen, waarin de inw. nas. reeds oerindonesisch was. Zodat de voorgeslagen verklaring mij niet de enig mogelijke schijnt te zijn. Daarbij zou men nog kunnen opmerken, dat zelfs al zou zij voor de inw. nas. wel de enig mogelijke, althans de meest waarschijnlijke zijn, dit nog niet im-

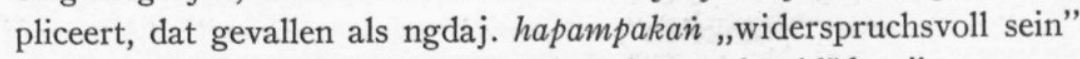

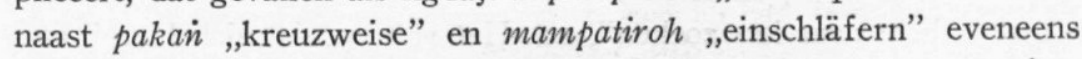
met een binnengedrongen $-m-<-u m$ - uitgelegd moeten worden. Trouwens, Dempwolff ${ }^{2}$ ) geeft toe, dat zijn hypothese niet alles verklaart: „Es bleiben noch eine Anzahl von Wörtern des Ng., in denen die Nasalverbindungen $m p \ldots$ (enz.) unaufgeklärt bleiben, da sie kaum auf die... auseinandergesetzten Vorgänge zurückgeführt werden können, weil die Bedeutung die eines Gegenstandes und nicht die eines Vorgangs ist".

Tot de vormen die met behulp van de -um- hypothese uitgelegd kunnen worden rekent Dempwolff ook ${ }^{3}$ ): pain Schallwort für

\footnotetext{
1) Dempwolff, o.c., p. 180 .

2) Dempwolff, o.c., p. 187.

3) Dempwolff, o.c., p. 180, 182, 184.
} 
„plumps” : měmpan் (neben měpan்) „plumpsen”, ton் Schallw. „bums”: měntón „bumsen”, cỉ Schallw. „klirr” : mincin „klirren”. Hij rekent deze vormen niet tot de ,gepraenasaleerde" ${ }^{1}$ ), omdat in dat geval de tenuis in de nasaal opgaat: pukul ,slaan" : mamukul etc. De vormen mĕndus (bij dus Schallwort "plumps”) „plumpsen” naast mĕdus, měngau (en mĕgau) „klopfen” naast gau Sw. „klopf” ${ }^{2}$ ) rekent hij wel tot de "gepraenasaleerde", aangezien een media in Anlaut niet in de nasaal opgaat: darah ,dicht bei, zunächst”: mandarah „nähern”; deze laatste woorden zijn niet door toedoen van ,das (hypothetische) Formelement $m$ " ontstaan. Lijdt deze voorstelling niet aan een innerlijke inconsequentie? Zien we rond in andere Indonesische talen, dan blijkt, dat in geluidswoorden en de daarmee zo vaak in vorm parallel gaande bewegingswoorden ${ }^{3}$ ) vaak het merkwaardige verschijnsel optreedt, dat zij zich niet gedragen volgens de in het algemeen geldende praenasaleringsregels. In het Maleis vindt men měnkěrèpètan ,knetteren”, měnkěrikit „,knagen”, měnikělějèpan ,knipoogjes geven”, vgl. jav. měnkirig „(even) te berge rijzen (van het haar) en rillen" : kirig ${ }^{2}$,een rilling door het lichaam voelen gaan”, měnkorog "steil overeind gaan staan (van haar of veren)", mĕntéyot ,wankel lopen (gebogen onder een zware last)”, méṅtělun ,buigen, gaan overhangen (van een tak)” : ditěluñaké „men laat buigen, tracht voorover te halen", měncělat ,wegspringen”, měnculat ,,sprongetjes maken (van kikkers)" : culat ${ }^{2}$,springen”, měnțè̀̀̀l ,liggende de kop oplichten”, měnținil ,uitbotten” : ținil „,id.”, měncènèl ,zich naar voren werken” : dicènèlaké „men laat te voorschijn komen”, mĕncěnis ,zich plotseling grijnzend vertonen” : cĕnis ,spottend grijnzen”, měncurat „sprankelen”, měncorò „,sterk schijnen” : (di)coroni „met 'n licht naar iets zoeken”, e.a. Het valt op, dat zich hierbij aansluiten een aantal woorden die een bepaalde wijze van zich voor te doen, zich vertonen of gedragen aanduiden, bv. in jav. mĕ „,eigenzinnig, lastig”, měnkělà „weerspannig”, měnkěluk ,,gebogen”, mĕnkĕlun் „gebogen vooroverhangen”, mě̀ikurẹ̆b „omgekeerd, zodat (van borden bv.) de holle zijde naar beneden ligt”, mĕnțalèt ,dooreengestrengeld”, měntélà „kwajongensachtig”, mențèsèl „met knobbels”, mĕncělèk „waarvan (oog bv.) het bedekkende vel is weggenomen”, měncěrěn ",boos kijken”, měncèrèt „glanzend”, měncilak „open (van de ogen)", měncinis "met het puntige eind te voorschijn komen",

1) Dwz. aan het begin van woord of grondwoord gepraenasaleerde.

2) Dempwolff, o.c., p. 189, 190.

3) Over een en ander Remarks, p. 164 vlgg. 
měncurěn „toornig kijken”, měncolèn „losbandig”, měnconol „opduiken”, mĕnținul „(met de kop) boven (water) komen”, mĕnțolos ,geheel glad (geschoren)" e.a. ${ }^{1}$ ). In het Sasaks is het regel, dat anlautende $k$ bij nasalering $>\dot{n}: k e k a h$,slachten" inekah, kěkěp „beschermen (onder de vleugels)" : $\dot{n} \check{e} k \breve{e} p$, maar we vinden er ook (n)ěrikikik „schateren”, (n)ěnikěběr ,vliegen”, (n)ěnikalěp „op de buik liggen”, (n)ěnkelak „op de rug liggen”, (n)ěnkěrok (vulgair) „,reperen". Zo kent het Atjehs meiněrěcěhok ,levendig en lawaaiig geluid”, men்ĕrĕduk „,dof geluid (op trommels)”, měngunjak „schudden", e.a. Hoewel ook het Soendaas geen verba, alleen met een praefix man்- gevormd, kent, vindt men er mankkĕrĕd „(ineen)krimpen”, naast murěnkěd, mantanul „ongehoorzaam, weerspannig”, mancainah „verwaand”, en daarnaast ook měndělik, mundĕlik, met wijd-open ogen zijwaarts staren”; dělek ,'n verachtelijke of boze zijwaartse blik werpen" (vgl. ook dilak), doch geheel vergelijkbaar měncěrèt „diarrhee hebben”, en ook moncoron (= mencran்) „stralen”, minculak „raar doen, anders zijn dan anderen”, mènpeyot ,zich verschrikt uit de voeten maken”, muncěrat "naar alle zijden heenspatten”, muncěrěn ,,iemand voortdurend strak aanzien”, muncugug „het hoofd in de hoogte houden", moncogog ,ongemanierd" : cugag, cugag-cagèg „lomp, ongemanierd”, moncoñok ,in gedachten verzonken zijn" etc., wederom dus bewegingswoorden en aanduidingen van gedragingen etc.

1) Men zou, in verband met wat Kern (Verspr. Geschr. 8, p. 207) opmerkt, nl. dat bij grondwoorden aanvangende met $b$ of $b h$ in het Oud-Javaans meestal bij de aanvangsnasalering $m$ i.p.v. $b$ of $b h$ optreedt, maar soms deze klanken behouden blijven, de vraag kunnen stellen, of dit laatste misschien bij dezelfde of dergelijke kategorieën van woorden plaats vindt als hier. Inderdaad vinden we ambakiti ,als mieren uitstromen”, ambankizwa ,zich als boshanen voordoen(de)", ambata ",als een muur", ambarat katiga ,als de wind in de 3e maand", mamberawa ,als b. fungeren”, ambhramara "als een bij gonzen of doen”, maar ook amidudak ,als een adder". Weliswaar bestaan ambandẹm ,werpen”, ambantin „neersmakken” (maar ook mamantiniakěn), ambaranaǹ ,'n overval doen”, ambahak „plunderen”, ambahud „ombrengen”, amběběn் „versperren”, amběběd „binden”, maar ook amubat „slaan” en ambhukti naast mamukti „genieten, nuttigen”, ambañcana naast amañcana „van zijn stuk brengen”. Een zekere expressief-affectieve functie van de nasaal lijkt mij ook hier niet uit te sluiten, in hoeverre gemechaniseerd en dialektisch of individueel kan ik niet uitmaken. Invloed van een elders in het woord aanwezige nasaal (vgl. Dempwolff, o.c. p. 195 voor het $\mathrm{NgDay}$.) valt hier niet aan te tonen: naast vormen waar de enkele $m$ optreedt als amaniun, amacaniah, amañcal, staan andere waar de occlusiva behouden blijft: pambañol, ambandẹm, ambaṇdun, mambandha, amběběn, en weer andere, waar beide gevallen zich voordoen: amañcana: ambañcana, mamantinakan : ambantin. 
Voorts bestaan er naast dergelijke driesyllabige uitdrukkingen gehelen van twee syllaben met eender begin en behorende tot dezelfde semantische kategorieën. Vgl. bv. Sas., waar (n)ęnkikik „schateren”

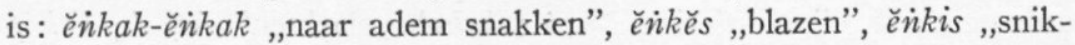
ken”, ě̀nkit „piepen (van de stem), sissen (van een slang)"; ěrikus „opsnuiven”, ěrikok „kokhalzen”, ěntěk „kloppen”, ĕntěl „,aanstampen”, ěncěk ,stappen”, ěncot ${ }^{2}$,met kleine tussenpozen uit iets spuiten". En zo is er in het Soendaas slechts een verschil in aantal lettergrepen (en bij woorden die een $r$ of $l$ bevatten kan dit nog schijnbaar zijn) tussen de vorige groep en woorden als : mèncran $=$ moncoron, munssat-mañsrèt „overal heenspatten” (vgl. boven muncěrat), en dan voorts met andere geluids- en bewegingswoorden als aikluk ,trippelen (van een paard)", ïkrik ,op een drafje lopen (als een varken)”, amprèt „spatten op iets" (vgl. de genoemde woorden voor ,spatten”): kèprèt ,het spatten”, kěmprà் „,de klank van het aanslaan van de draad bij het weven”, kĕmprun், íĕmpruí ,,aanhoudend klinken (van muziekinstrumenten)”, kompyan் „ritselen”, cěmplun „,het plompen van een in het water vallend voorwerp", cèmprag ,met een sprong op een rijdier gaan zitten”, coìklan „galopperen”, enz. enz., specimina, die hier reeds genoemd mogen worden. Zo kent ook het Javaans woorden als měnkis ${ }^{2}$,hijgen”, mě̀nkus ,id.”, měnțèt ,,met de vingers knippen naar iets", mĕncok ,afkappen”, mĕnțon் ,op een signaalblok

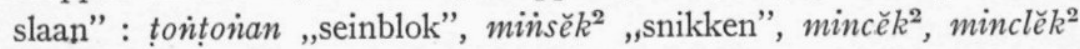
„met kleine stapjes lopen”, mintugg „waggelend lopen”, mlěncat „,wegspringen”, mlěncï „,er van door gaan”, muncar „(van water) in de zon schitteren”, muncit „spits uitlopen”, muncrat „opspatten”. Vergelijk ook Maleise woorden als mancit „bij korte tussenpozen uitspuiten”, mancut „met een straal naar boven spuiten”. In het Atjehs: mĕntik „opspringen (van kleine visjes boven het water)", etc. Ook lette men op jav. gěbibir : gěbimber „bibberen, rillen”, gedempalan ,haastig achternalopen”, en dergelijke.

Dempwolff analyseert de drie woorden mempan, menton en mincin $\left.{ }^{1}\right)$, die ieder het enige voorbeeld van hun soort zijn, als volgt: praef. me- (in mincin tot mi- geassimileerd) + nas. ontstaan uit -um-, dat hier in de eerste syllabe zou zijn geinfigeerd, plus de Schallwörter pan etc. Maar is hier voldoende rekening gehouden met de aard van het element $\left.m e-?^{2}\right)$.

1) Zie boven, p. 151 en 152.

2) Hardeland, o.c., p. 48: „me - der einzelne Fall wo ein Präfix einen andern Vocal als $a$ hat, stellt sich vor lautnachahmende Interjectionen, die 
Het wil mij toeschijnen, dat deze Dajakse vormen eerder te vergelijken zijn met Soendase formaties als prat-prèt „klanknabootsing van het druppelen van een weinig regen" : amprèt ,spatten op”; prok „ww. tuss. voor ontmoeten" : $a(m)$ prok ,samentreffen"; srut „id. voor iem. ontlopen (van de ontlasting)": munsrat-mansret „overal heenspetten", met 't zoëven genoemde atj. měntik, met mal. cit ,gepiep van muizen” : děcit ,piepen” en měncit „piepen”, min.

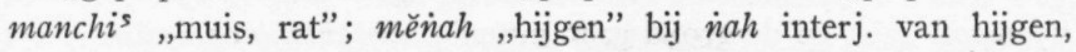
měñua ,loeien” bij uak interj. van loeien, jav. měrikirig (z. boven), měntělun் (z. boven) e.a. naast kirig etc. en allerlei dergelijke vormen.

Gelijk bekend ${ }^{1}$ ) worden ook in Indonesische talen de nasalen in onomatopeeën, klankexpressieve woorden en wat zich daarbij aansluit vaak gebruikt. Een woord met een of twee nasalen bezit een zekere geschiktheid om, onder medewerking van andere omstandigheden, een indruk te wekken, die analoog is aan die van galmende, gonzende, zoemende, weerklinkende, langdurende, zware geluiden. Men denke aan mal. děnun „galm”, běrděṅun் ,gonzen, brommen, loeien etc.”, dĕṅkon ,het geluid van zwaar gehamer”, n்aun „,weer-

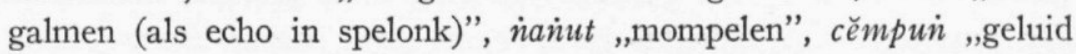
van geplons", bar. mbombe, klanknabootsing van dreunende of brommende geluiden)" ${ }^{2}$ ), kambombe „brommend etc. leven maken”, jav. beniiǹ̀h „hinneken”, klènkèn ,,janken”, kĕnțonan „signaalblok”,

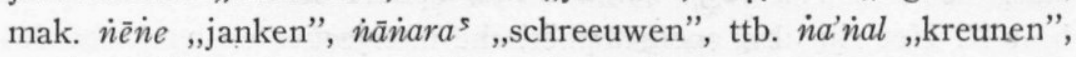
mori $n t u a^{2} \dot{n} i$,schelptrompet” : mal. tuan் ${ }^{2}$.

Evenzo in onomatopoëtische interjecties ${ }^{3}$ ) als mal. $\dot{n} a h^{2}$ (hijgen), $\dot{n} a p^{2}$ (naar adem snakken), $\dot{n i n}$ (klingelen), enz. En bovendien zien we, dat menigmaal een onomatopoëtische interjectie of vergelijkbaar element, ,waarop een grondwoord gebouwd" ${ }^{4}$ ) wordt, een door nasaal gevolgd formatief voor zich krijgt, anders gezegd, in een vorm met inwendige nasalering optreedt: bij het genoemde mal.

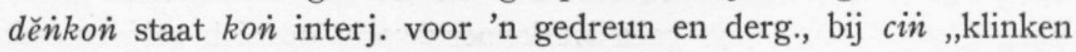
(van munten etc.)" : děcin en děncï̈, bij cur onom. interj. voor spuitend enz. water : děcur ,zo'n geluid voortbrengen”, maar pancur „naar beneden etc. uitspuiten”; $\operatorname{tam}, \operatorname{tam}$ „士 stamp, bons, boem” :

dadurch quasi zu Verben werden, indess auch ganz als Interjectionen gebraucht werden können, zB. gor, megor „donnernd", gor (oder megor!) huma balongkang heta" „donnernd stürtzt dort ein Haus ein"...".

1) Vgl. hierbij ook Remarks, p. 183.

2) Adriani, Bare'e-Ned. Wdb., p. 437.

3) Waarover Opmerkingen... Comparatieve Methode, p. 445.

4) Zie bv. Brandstetter, Wurzel und Wort (in Blagden's vertaling Essay I), § 87. 
dĕntam ,een zware plof”, děntum „dreunen”, gĕrětam en gĕrĕntam „,id.”, $\tan$ on. int. v. geluid van zwaar vallend metaal, ti் ,geklink”,

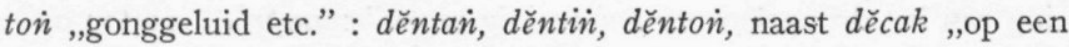
bepaalde wijze hinken of huppelen”; děncoí, bij kèn ${ }^{2}$ „gejank van honden” : děnkin „schel hondegejank”, děnkur „snorken”, en zo in het Javaans: naast klak-kluk ,telkens knappend (van gebogen gewrichten)": dẹ énklak-dẹnkklik „doorknikken (gewrichten)”, pok „plof”: ndèmpok ,plat op de grond gaan zitten", kĕnțonian, enz.

„Bij stammen die klanknabootsingen zijn”, zegt Adriani ${ }^{1}$ ) over het Tontemboan, ,zal men dan ook dikwijls als aanvangsklank een nasaal vinden, bv. (tontemb.) $\dot{n} a^{\prime} \dot{n} a k$, ts. $\dot{n} a k \dot{n} a k$,een naar zijn geluid genoemde roofvogel”, ... niaon , geschreeuw van katten” etc..$^{2}$ ) „In levendigen stijl gebruiken de Bare'e-sprekende Toradja's", gaat hij verder, „bij wijze van tusschenwerpsels werkwoordstammen, die beweging, geluid of krachtsinspanning aanduiden; van aldus gebruikte werkwoordstammen wordt steeds de beginner gepraenasaleerd". Voorbeelden: mesua kita sima'i ri botutu, jamo ${ }^{3}$ ) mpindi $i^{2}$ pemama nojo ${ }^{3}$ ) „,kwamen we buiten het gordijn, dan ging maar pik, pik het steken

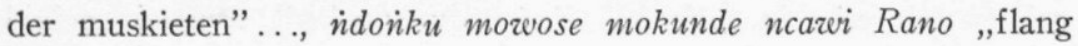
(met de steel der schepriemen tegen de wand der prauw stootende) roeit men de Posso òp tot aan het Meer"..., inkunda ranasu ,òp steeg de rook"..., ndidi natunju lipu, ,poef! stak hij het dorp in brand". Het zijn dus onomatopoëtische interjecties en werkwoordelijke tussenwerpsels, zoals we die bv. uit het Soendaas zo goed kennen, doch gekenmerkt door consequente aanvangsnasalering. „De voorbeelden van deze soort”, voegt Adriani er aan toe, ,zouden nog belangrijk kunnen vermeerderd worden, maar de bovenstaande zijn ruimschoots voldoende om aan te tonen, dat de prenasalering wordt gebruikt om een geluid, eene beweging, in 't algemeen eene werking als ineens geschiedende voor te stellen. De geprenasaleerde werkwoordstam, hoewel nog geen werkwoordsvorm op zich zelf en ook nog buiten het verband van den zin staande, heeft toch reeds een begin van vorming ondergaan..$\left.{ }^{4}\right)$. Zo vindt men in dezelfde taal naast kanda „stappen” : íkanda ri ineña „stap! op zijn moeder af”,

1) Adriani, De intensieve of activiteitsvormen in eenige talen van Indonesië, in Versl. en Meded. der Kon. Akad. v. Wet. Amsterdam, Lett., 4e reeks, 9 (1909), p. 329.

2) Zie voor het Tontemboan ook Schwarz-Adriani, Hoofdstukken uit de Spraakkunst van het Tontemboansch (1908), p. 79.

3) Adriani spelt djamo en nodjo.

4) Adriani, o.c., p. 330 vlg. 
naast polu „neerhurken” : mpolu mandiu ,ineens op de hurken om te baden" en dergelijke ${ }^{1}$ ). Deze ,gepraenasaleerde stammen", zoals meergenoemde auteur ze noemt, kunnen als grondwoorden voor nieuwe vormen fungeren, zo wincanda, wuncanda $=$ ncanda, ,ineens te voorschijn komend" 2). Gelijk bekend, vormt het praefix mo- o.a. met grondwoorden die een geluid etc. aanduiden het uiten van dat geluid: mokere ${ }^{2}$,,de (vogel)geluiden kere ${ }^{2}$ voortbrengen”, ook met praenasalering: monkkokoti „knagen, knabbelen”. Daarnaast heeft het een betekenis „zich vertonende als...”. Bij het praefix $m \breve{e}$ - is, vóór een substantivisch grondwoord, zeer gewoon de betekenis ,de vorm aannemen van, het model vertonen van, gelijken op dat wat het grondwoord aanduidt": měkorika „doen als een kiekendief”, mĕntono „zich als een wig (tono) indringen" etc. ${ }^{3}$ ). Men vergelijke daarbij de bovenvermelde Javaanse voorbeelden. Als beweging-aanduidende woorden liggen grondwoorden met aanvangsnasalering er ten grondslag aan de vorming van werkwoorden, met een verschil in betekenis, dat door Adriani als intensief ${ }^{4}$ ) is gedefiniëerd en in zijn in de noten genoemde werken in den brede is beschreven.

Anders gedraagt zich het Morisch van Tinompo ${ }^{5}$ ). Is de aanvangsnasalering ,met intensiverende kracht” bij geluids- en bewegingswoorden in het Bare'e zeer frequent, in het Mori is ze niet gewoon; de bovenvermelde tussenwerpsels komen er nagenoeg niet voor. Maar ook hier treden in woorden die een indruk op het gehoor of gezicht weergeven vaak nasalen of gepraenasaleerde klanken op: $\dot{n} a s a$,hijgen” (vgl. mal. kěsah), ìkundu ${ }^{2}$, ,een kloppend geluid (bv. op hout)", mengere „brommen (van een hond)”, mo-mbubu ,een bobbelend geluid maken", mbimbiri ,'t geluid van een geworpen steen in de lucht", mondidi $i^{2}$,beven (van kou of woede)" etc.

Het wil mij nu voorkomen, dat niet alleen in de genoemde Celebestalen, maar ook in de andere, waaruit hierboven voorbeelden zijn meegedeeld, inclusief het Ngadjoe-Dajaks, de hier in aanmerking komende nasaal in geluid- en bewegingsaanduidende woorden en in de semantische kategorieën, die zich daarbij in hun gedrag ook elders en anderszins wel aansluiten, in de eerste plaats te zien is als een element in het onomatopoëtische, Lautbild-, klanksymbolische geheel

1) Adriani, Spraakkunst der Bare'e-taal, Verh. Bat. Gen. 70 (1931), p. 44.

2) Adriani, Spr. Bare'e-taal, p. 44 vlg.

3) Adriani, Spr. Bare'e-taal, pp. 148, 153, 150, 162, 166.

4) $\mathrm{Bij}$ deze benaming sta ik hier niet stil.

5) Esser, Klank- en vormleer van het Morisch I, Verh. Bat. Gen. 67 (1927), p. 20 vlg. 
dat het woord in kwestie vormt, als een element, dat het zijne bijdraagt om zo'n woord een zekere inhaerente geschiktheid te geven en te doen behouden om bepaalde begrippen op effectief-expressieve wijze tot uitdrukking te brengen ${ }^{1}$ ). In ngday. mincin ,,rammelen, rinkelen" lijkt mij, evenmin als in mal. mancit, jav. měnțèt etc. (zie boven), sprake te zijn van een infix nasaal $-m-<-u m$ - met een overigens niet te definiëren logische betekenis.

Maar een dergelijke nasaal of gepraenasaleerde klank is niet beperkt tot de aanvang van het grondwoordelijk deel van het woord, zij het dat dit (zoals de regel is) twee-syllabig is, zij het, dat het als to $\dot{n}$, sar, cin, tup en derg. eensyllabig ${ }^{2}$ ) is.

Het lijkt mij verantwoord in een groot aantal geluids- en bewegingswoorden in IN. talen, waar nevenvormen mèt en zonder nasaal worden aangetroffen, aan deze nasaal een althans oorspronkelijk of potentiëel affectief-expressief karakter $^{3}$ ) toe te schrijven; vaak zal het juister zijn te zeggen, dat de nasaal deel uitmaakt van het zodanige klankbeeld van het gehele woord. Ik denk daarbij aan woorden als mal. gělasar : gělanisar ,uitglijden”; hier en in verscheiden andere gevallen wijst ook het naast elkaar bestaan van vele vormen ( : gělanisir, gělansar etc. ${ }^{4}$ ) op dit karakter; voorts gĕlècak etc. : gĕlincir „struikelen, uitglijden”, gĕlědin : gĕlěntin ,ineenschrompelen”, gĕlětar : gělěntar, gĕmětar, gĕměntar „beven, huiveren”, gĕmĕrĕcèk : gĕmĕrĕncèk „,besprenkelen”, gĕrĕtam: gĕrĕntam, naast dĕntam,

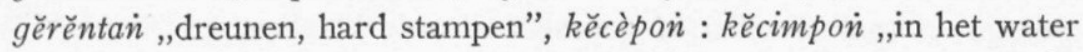
plonzen" (met vele nevenvormen), kělětak, kĕlětèk, kělětok, kĕlětan : kĕlěntain van verschillende hamerende en bonzende e.a. geluiden (men lette ook op de wisseling $-k:-\dot{n}$ in Auslaut), kělěto $\dot{n}$,,voortdurend op een weerklinkend voorwerp slaan” : kĕlěntò „e.s.v. houten klappers", mor. karantoĕ naast bar. karatǒ ",een lange smalle trom" ${ }^{5}$ ); boeg. mancï ,klinken van ijzer op ijzer" : mak. macin (gamacin,

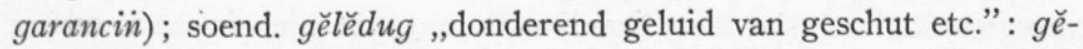
lěndun ,een dof geluid geven, zoals een vallend voorwerp”, gĕrĕdĕg „geluid van een voortrollende wagen” : gĕrěndun „hol klinken”; niricik : ñarincik „,neervallen (van een fijne regen)"; mak. gamacin :

1) De zg. phonaesthetische functie van Firth, waarover (met literatuur) N. van Wijk, Phonologie (1939), p. 101.

2) Vgl. hierover bv. Brandstetter, Wurzel und Wort (Brandstetter-Blagden, Essay I), § 64 vlgg.

3) Waarover Opmerkingen ... Comp. Methode, pp. 419 vlgg.

4) Opsomming bij Wilkinson, A. Malay-English Dictionary I (1932), p. 338.

5) In het Sa'dan garaturi. 
garancin "rammelen", mak. caléperes : calímperes „babbelen" $\left.{ }^{1}\right)$.

Ook in tweesyllabige geluids- en bewegingswoorden - dwz. in die welke niet als de genoemde van een eerste deel voorzien zijn $^{2}$ ) dat bij deze semantische kategorieën frequent is - zal men vaak aan dezelfde ,verklaring” der aanwezigheid van de nasaal moeten denken, bv. in soend. gombrain ,het rinkelen”, gonjrain ,het rammelen van geld”, goinsen் „rinkelbel”, kĕncren் „rinkelen van weinig geld”, kentruin „een hol, galmend geluid geven”, kunclun ,,in het water plompen”; jav. kemprai „kletterend neervallen”, klinkinan ,,janken”, munkok „kokhalzen”, kempyain „luidruchtig”, kemprui ,daverend lawaaiï", genjlun „,met een plof neervallen”, genjrèn „tamboerijn”. Zo mal. ginsirir : gìsèr „schuren langs”; pĕikis: pěkis „hoonschreeuw", dĕncin : děcin ,rinkelen”; vgl. ook bat. ${ }^{3}$ ) mal. loncè „,bel" = locen (leenwoord); bewegingswoorden zijn ki(n)tar, lo(n)tar, vgl. rĕcik : rĕncik ,spatten”. Voorts mori ${ }^{4}$ ) bembe „,klanknab. woord voor geit”, tinti ,geluid van de gong”, (mompa)ikundu ,iets doen botsen tegen iets anders, zodat het geluid ìkundu ontstaat", bare'e :

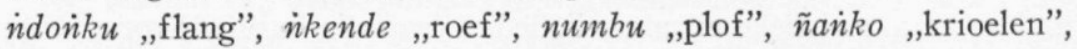
ingingo „spartelen”, mbombe, mbombo ,gonzend, dreunend geluid”,

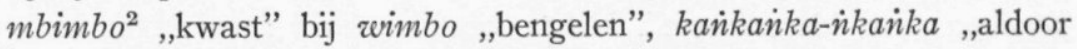
krabbende”; kandende-ndende „bevende”, tont. mainombal ,kraaiende jonge haan”, ng.-day. salentak „Klapp mit der Zunge” naast bitak „,babbelen”, kotak „spreken”; soemb. bumbur „opborrelen”, janjak

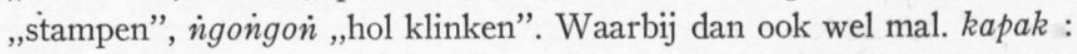
kampak „bijl” etc. Voorts mori polorundu „donderen”, polotumpe ,het geluid van iemand, die valt" ${ }^{5}$ ).

Woorden die begrippen uitdrukken welke een zekere gevoelswaarde met zich mee brengen treden meermalen in varianten op, en ook hier is de nasaal, naar het mij wil voorkomen, vaak ,met affectieve waar-

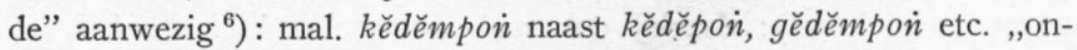
gezond opgezwollen etc.”, (gěmok-)gĕděmpon் „vet, dik, met grote billen” : gĕdipoì „,de billen”, gělambir, gĕlember etc. „vleeskwab”,

1) Zie bv. ook de typen van woorden voor bewegingen die zich aan de zintuigen levendig voordoen bij Van der Tuuk, Tobasche Spr., p. 122.

2) Of men dit nu al (zo bv. in het Mori) dan niet (bv. in het Maleis) een praefix pleegt te noemen.

3) Zie Wilkinson, Dict. s.v.

4) Voorbeelden ontleend aan Esser, o.c., passim.

5) Esser, o.c., p. 344, vgl. p. 38.

6) R. A. Kern spreekt Bijdr. 92, p. 16 en elders, zonder nadere toelichting, over intensieve betekenis der inwendige nasalering. 
gĕlimbir : gĕlibir „hangwang”, gerinsïn : gerisin̈ „(bij lelijke smaak of geur) zich vertrekken (van mond of neus)", jĕrembet naast jĕrepet „verbonden, maar onafhankelijk kunnende bewegen”, jĕrumbai naast jĕrambai, jĕrabai „uitgerafeld, met kwastjes, franjes etc.”, tělukup, tĕrlukup: tĕluinkup, tělan்kup „met de bodem naar boven liggen”, lepek : lempek „(als een veer of blad) langzaam vallen”, mal. Djoh. conkah-mainkeh, naast Ked. cukah-makeh ,with projections here and there; untidely arranged; in disorder”, sěmbat, sambat, sabat „met een buigzaam of zwepend voorwerp slaan enz."; gělincir, gĕlinsir naast gĕlecak hebben naast het karakter van bewegingswoorden vermoedelijk ook een zekere gevoelswaarde (vgl. gelanisar : gĕlasar ,uitglijden" en derg.). Bij deze groep mag men wellicht ook aan jav. binantan $=$ binatan ,beest (als scheldwoord)" denken.

Ook namen van gebruiksvoorwerpen en dergelijke, sieraden, onderdelen van grotere bouwwerken, instrumenten, etc., die vaak in de sfeer van de primitieve woordvorming ${ }^{1}$ ) - om het zo uit te drukken - vallen, hebben meer dan eens een ,epenthetische nasaal" naast andere karakteristieke eigenaardigheden (variatie in woordvorm bv.): mal. guci : gěmunci „waterkruik”, gĕdaga: gĕndaga, kĕndaga, pĕndaga ,esv. klerenkistje”, kĕdit : kĕndit, gĕndit ,gevlochten buikband”, kĕdělam : kĕndĕlam „esv. drinknap”, cěropoin : cĕrompon் (vgl.

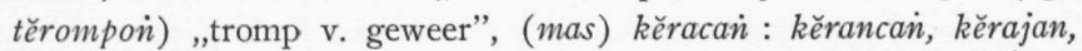
gĕracan் „goudblad”; dial. mal. godam : gandin, gegandin „zware hamer", bepaalde spijzen en lekkernijen : napal : nampal ,e.s.v. eetbare aarde”, tapai : tampai „e.s.v. gekookte rijst”. Dan ook woorden als tomb. atĕlu: day. hantěloh, ojav. antělu ,ei”; bar. apoju: mal. ampědu „gal”; tag. labi : jav. lambé „lip”; tomb. tond. kalipopo : tont. kalimpopoan "vlinder”, d.w.z. namen van lichaamsdelen, bepaalde dieren etc., die zich in eigenaardigheden vaak bij de vorige groep aansluiten ${ }^{1}$ ); daarbij ook mal. bogok : bongol, boinkol etc. „knobbel, etc.”.

Mag men niet in de genoemde en andere woorden, inclusief die, welke onaangenaam treffende eigenschappen (zich onregelmatig of in bijzondere houding voordoen en dergelijke) uitdrukken, een zekere affectief-expressieve waarde van de nasaal - natuurlijk in verband met het woordbeeld als geheel - aannemen? En mag men niet deze ,inwendige nasalering” wat dat betreft op één lijn stellen met woorden die tot dezelfde of naverwante semantische kategorieën behoren,

1) Zie Opmerkingen over... comp. methode, p. 451. 
doch Anlautsnasalering vertonen? Het is immers nauwelijks te ontkennen, dat hieronder vele "primitieve" woorden ${ }^{1}$ ) schuilen: in het

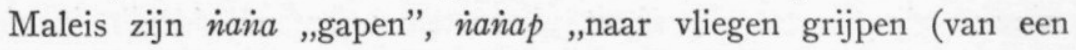

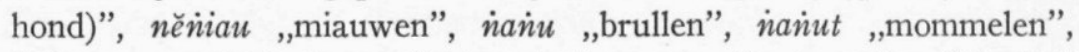

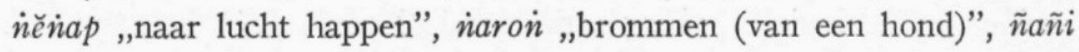
„zingen”, etc., en daarnaast i்ĕlu ,een zwaar gevoel in het hoofd

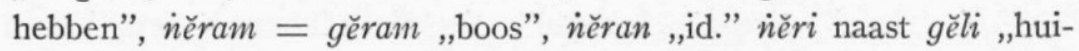
veren”, ínikiik „sukkelen”, íilu „pijnlijk stram (in de gewrichten)

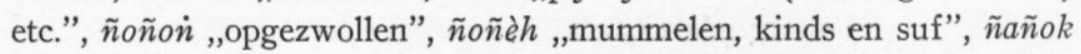
„suf, kinds”, mamah „kauwen (in gesloten mond)”, mamai ,verward, kinds etc."; in het Tontemboan mbaon ,geluid van een kat", mbes ${ }^{2}$ „naam van een vogel” etc. ${ }^{2}$ ). Ook in het Tontemboans vindt men van woorden die een doordringend gevoel of een sterken smaak aanduiden als aanvangsklank een nasaal: $\dot{n e r r u ~, v i s-~ o f ~ v l e e s l u c h t ”, ~ i ் i l u ~}$

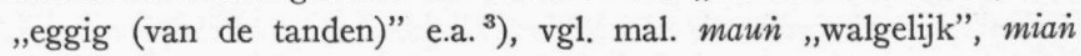
,jeuk".

Ik heb een vrij groot aantal Oud-Javaanse doubletten (vormen met en zonder nasaal) nagegaan, en daarbij is mij opgevallen, dat zeer vaak het door het woord uitgedrukte begrip zich tot uitdrukking onder

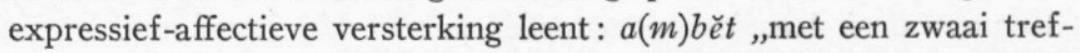
fen”, $\breve{e}(n) t a l$,,beroven”, $\breve{e}(m) b u s$,,snuiven”, igu ,beven, schudden”: ingun ,heen en weer schudden, waggelen”, idĕr ,ronddraaien”: $i(n) d \breve{r} r$,voortdurend ronddraaien, rondtollen”, usir ,,achterna gaan”: unsir ,zijn toevlucht zoeken tot, streven naar”, $u(\dot{n})$ sil ,zich bewegen”, $u(\tilde{n}) c a l$,slip, sjerp”, $u(n) t a l$,wegslingeren”, $u(m)$ pĕt ,laken,

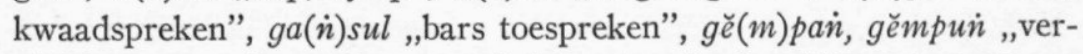
nield, verwoest”, cagingar : caingigĕr „kraaien”, takĕp, takup „tegen

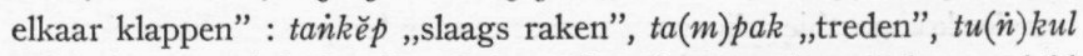
„zich (voorover) buigen”, rěbah „vallen, instorten”, rupuh „vernield

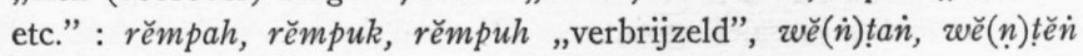

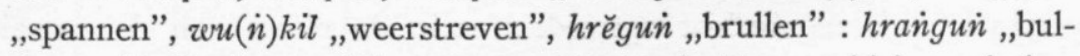
deren, brullen", c.a. Hiertegenover staat slechts een kleine minderheid van doubletten die andere begrippen tot uitdrukking brengen: bv. akĕn : à̉kĕn ,te beschouwen als". Ook meer in het algemeen valt onder de Oud-Javaanse woorden van ons type een grote frequentie van voor expressieve uitdrukking bijzonder vatbare begrippen

1) Over deze term Opmerkingen over ... comp. methode, p. 419.

2) Schwarz-Adriani, o.c., p. 11, n. 5 .

3) Adriani, Intensieve vormen, p. 329; Schwarz-Adriani, Hoofdst. Spr. Tont., p. 79. 


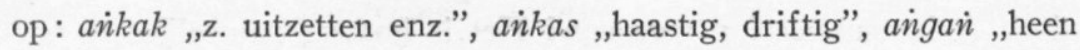

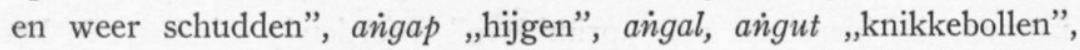
aìgěk, aingut „stoten”, ingut ,heen en weer schudden”, inguh „draaien”, insěr „draaien”, uñcar „spatten”, unduh „afschudden”,

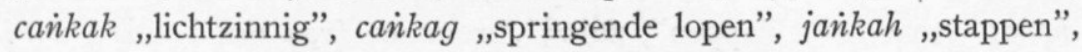
dĕmpěl ,dicht op elkaar”, tampuh „,beuken”, těmbaì ,slaan, geselen”, tĕmbun „slaan”, timpan் „kreupel”, timpal „afhouwen, wegsleuren etc.”, tumbak „met lansen steken”, tumbuk „stoten”, bantin „,neersmakken”, rĕngut „rukken”, rěmpu ,verbrijzelen”, rěmpuk, rĕmpuh „,id.”, ringěk „,waggelen”, ringun் „schommelen”, rimpun் „verminkt”, rimbit „versperd”, runkkuk ,gebogen”, luñcat „springen”, lumpan „stampblok”, lumpat „springen”, wantin ,neersmijten”, wantus ,samenstoten”, hantöb „neersmakken” enz. enz., waarbij nog komen zuivere geluidnabootsende althans ,geluids”-woorden als: kiñcin ,rin-

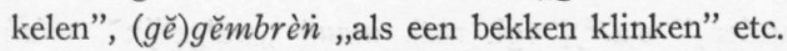

Dat de nasalen in onomatopeeën, klankexpressieve woorden etc. een gewichtige rol spelen, is van algemene bekendheid. ,Quand une nasale suit une voyelle dans la même syllabe elle constitue, grâce à sa qualité de continue sonore, comme une résonnance qui prolonge cette voyelle; il en est ainsi dans les onomatopées pim et bim-bam-boum ..., et dans lat. tintinnabulum, fr. il résonne, all. brumbär, brummglocke, klingen, klang, gr. klaggè, lat. clangor, all. trommeln „battre le tambour”, gr. brontè „,tonnere”, v. sl. gromŭ „tonnerre”, gr. bombos „,bourdonnement” ${ }^{1}$ ). „Der nasale Auslaut gibt den Wörtern etwas Sonores: eng. clang, twang, bang, drum, boom'" ${ }^{2}$ ). Men denke aan Nederlandse woorden als strompelen, mompelen, donderen, denderen, en vele andere. Verdere voorbeelden zullen beneden nog ter sprake komen; hier dienen we eerst een ander punt te bespreken.

Het is mij opgevallen, dat soms als tegenhanger van een woord met inwendige nasalering in een IN. taal in een andere taal een etymologisch aequivalent optreedt waarin de plaats van de nasaal wordt ingenomen door een liquida, speciaal $r^{3}$ ). Bv. mal. simpain(an)

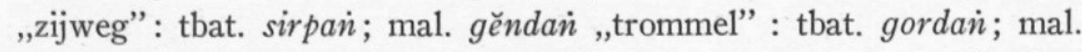
biinkis(an) ,geschenk (meegenomen)”: k.bat. bĕrkis „bundel”, tbat. borhos, tag. bigkis $(g<r)$; verder gaande kbat. těrpuk ,afdeling”:

1) M. Grammont, Traité de phonétique (1933), p. 388.

2) Fröhlich, Zusammenhang zwischen Lautform und Bedeutung bei englischen Wörtern, Die Neueren Sprachen 33 (1925), p. 33.

3) Daarnaast wel eens een geval als kbat. lintan "striem (op het lichaam)": listan „rechtlijnig”. Vgl. ook min. mantika „bezoar”: mal. mĕstika. 
mal. tumpuk. Vergelijk voorts gevallen als jav. kampèk : kĕ(r)pèk : „mand, koffer, zak”; tbat. jomba: jorba „scheef”; tbat. hĕmban „,uitgespreid”: hĕrbain „(vleugels etc.) uitspreiden”; naast min. sandao „oprispen” : mal. še (r)dawa.

$\mathrm{Nu}$ treedt deze wisseling niet alleen op in het midden van tweesyllabige woorden, maar ook, in drie lettergrepige na de eerste syllabe. Men denke aan de vrij talrijke plantnamen in het Maleis die zowel

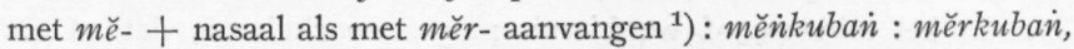
mě̀ikucin : mĕrkucin, mĕṅkuli : mĕrkuli, mĕṅkunyit: mĕrkunyit, měntajam : mĕrtajam, měntapai : měrtapai, měmpělam : měrpělam ${ }^{2}$ ),

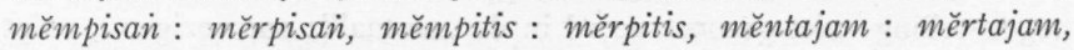
mĕntimun : mĕrtimun, e.a. Voorts mal. mĕntua „schoonouder(s)": mĕrtua. Dat verder Maleise woorden als gěmerrsik ,'n aanhoudend krassend geluid”, gěměrtak „kraken”, gěměrtap „,ruisen (van de regen)", gěmerrtup ,donderen” en dergelijke in vorm en semantisch met gĕměntam „donderend geluid”, gĕrěntam „dreunen” etc. vergelijkbaar zijn, is duidelijk. En zo zou ik těriak „schreeuwen” (cf. iak, měniak „kermen”, kĕriak „schreeuwen”) met měncit en derg. vergelijken.

Ook in leenwoorden vinden we verschijnselen die we in dit verband even opmerken. De Indische liefdegod Manmatha behoudt deze vorm van zijn naam ook in het Oud-Javaans, maar heet in het N.-Jav. ook Marmata, in het Maleis zelfs Merpata; port. manteiga luidt in Mal. en Jav. měntéga en měrtéga; (o.jav. prajurit verschijnt in het Mal. als perrajurit, pěrjurit, pěnjurit). Voorbeelden uit niet-Indonesische talen zijn ook hier aanwezig: naast lit. burbulas staat bumbulas „waterblaasje”, de Duitse nachtigall heet eng. nightingale, deens nattergal ${ }^{3}$ ), vlaams achtergoal.

Daar nu, zoals we beneden zullen zien, in allerlei talen na en naast de nasalen speciaal de liquidae bij de ons hier bezig houdende verschijnselen betrokken zijn (als „epenthetische” consonant optreden), lijkt het mij de moeite waard, de woorden, die tussen hun beide vocalen $r+$ cons. (soms $l+$ cons., bv. tb. golmok ,dik zijn” : gamuk) hebben in een aantal Indonesische talen, dus het type mal. terrbit, eens nader te beschouwen. Merkwaardigerwijze zijn zij door

1) Voor de ,vertaling” zie Wilkinson, A Malay-English Dictionary, II (1932), s.v.

2) Waarover R. A. Kern, Mal. mĕmpělam en verwante woorden, Bijdr. Kon. Inst. 90 , p. 145 vlg.; ik zou měn-, mĕr-, min. mara- echter in het huidige stadium der talen geen praefixen, maar formatieve elementen noemen; zie p. 170, 171.

3) Jespersen, The nasal in Nightingale, Engl. Stud. 31 (1902), p. 239. 
Brandstetter naast de taptap- en lintah-woorden niet als afzonderlijke groep genoemd. Hun aantal is zeker minder frequent dan dat der ,n-woorden", en niet iedere taal kent ze. In de 164 bladzijden lange lijst van Oeraustronesische ,constructies" in het derde deel van Dempwolff's Vergleichende Lautlehre komen geen andere typen dan taptap, lintah, mata-woorden voor, geen terrbit-woorden; voor de „oertaal" heeft genoemde auteur ze dus niet kunnen construeren. Ik laat in het midden, of we hieruit mogen concluderen, dat ze ten tijde dat „de Indonesiërs” nog ,een zekere eenheid” vormden ook werkelijk niet voorkwamen: een feit is, dat ze er nu zijn. En uit deze tegenstelling: niet geconstrueerd in de „oertaal”: aanwezig nu, volgt dat deze $-r$-woorden een discutabel probleem zijn op het terrein der Verg. Indon. Taalwetenschap. En al zal een restloze verklaring van het voorkomen ook van deze vormen niet mogelijk zijn, door de genoemde omstandigheden lijken zij mij een onderzoek in meer dan een opzicht minder moeilijkheden in de weg te leggen dan het lintahtype. Onderbreken wij derhalve onze beschouwingen over de laatstgenoemde soort en overzien we in het kort en voorzover nodig de terrbit-woorden.

In de eerste plaats: in de Bima-Soemba-groep is een bekend verschijnsel de ",omzetting”, in het bijzonder bestudeerd door Jonker ${ }^{1}$ ). In vele gevallen zijn daar vocaal en consonant van de laatste syllabe van plaats verwisseld: uit indon. kulit ,vel, bast" ontstond lett. ulti, tgr. jav. lumut ,mos” staat lett. lumtu, het ned. meester is lett mesra geworden; naast mal. berrat heeft het Letti perta, naar mal. garut : kartu etc. Al moge Jonker wellicht niet met al zijn verklaringen in detail het juiste getroffen hebben, er is alleszins voldoende evidentie om te concluderen, dat in deze talen consonantencombinaties, o.a. $r$ (of $l$ ) + cons. zijn ontstaan uit oudere vormen die deze of dergelijke combinaties niet hadden.

Door Brandstetter ${ }^{2}$ ) en anderen is meer dan eens de opvatting uitgesproken dat het tĕr- in Maleise woorden als tĕrkam, těrkap, tĕrbit, tĕrban், jav. tĕrbis etc. identiek zou zijn met het bekende praefix mal. tĕr- in tĕrhĕnti, tĕrtahan, těrcěnàn. Het wil mij voorkomen, dat het de weg tot juist begrip kan afsluiten, wanneer wij a priori de identiteit van formatieve elementen als $k a$ - in jav. kapal „eelt” en těr- in mal. terrkam met afleidingsaffixen die er in vorm

1) Zie bv. zijn Lettineesche Taalstudiën (VBG. 69, 1932), p. 2 vlg.

2) Brandstetter, Prodromus (1906), p. 17; vgl. Wurzel und Wort, § 86, IV; 95. 
mee overeenkomen aannemen. Deze opmerking sluit, overbodig te zeggen, niet de mogelijkheid uit, dat de ontwikkeling van het wetenschappelijk onderzoek op den duur tot aanvaarden van identiteit, hetzij in een of enkele gevallen, hetzij op ruimere schaal, zou kunnen leiden. Reeds Van der Tuuk heeft - m.i. niet de enige ten onrechte door lateren veronachtzaamde aantekening in dit boek - er in zijn Tobasche spraakkunst tegen gewaarschuwd, těr-van mal. tĕrban met „het bij het passief gebezigde voorhechtsel” gelijk te stellen ${ }^{1}$ ). Iets anders is, dat het gedrag van de $r$ van het praefix leerzaam kan zijn voor, parallel kan gaan aan dat van de inwendige $r$; zelfs kunnen er woorden zijn, waarin we wel tot identiteit kunnen besluiten.

Daarbij is in het oog te houden, dat zowel in praefixen als ook elders een door de inheemse bevolking of door ons in schrift genoteerde $r$ niet steeds dezelfde waarde heeft. De ,uitspraak" van de $r$ kan, gelijk bekend, zeer wisselen, en deze variatie is op Indonesisch terrein ruimschoots aanwezig: hier vinden we uvulare, daar tongspits $r$, ginds weer een andere opgegeven ${ }^{2}$ ), soms wordt hij zwak en nauwelijks hoorbaar, zacht brouwend uitgesproken ${ }^{3}$ ), of er bestaan individuele verschillen ${ }^{4}$ ), de uitspraak van de voorafgaande vocaal kan door de $r$ beïnvloed worden ${ }^{5}$ ), ofwel we vinden vermeld, dat in overgenomen woorden de consonantcombinatie waarin $r$ of $l$ de eerste is wordt opgeheven en dat na de $r$ - een ,vocale naslag” optreedt, bv. bim. soròga $<$ sorga ,hemel" "), of ook men constateert, dat in een dergelijk geval de $r$ verloren gaat. Er kunnen dissimilatieverschijnselen optreden als in mal. bělajar $<$ bĕr-ajar. In het Sasaks vinden

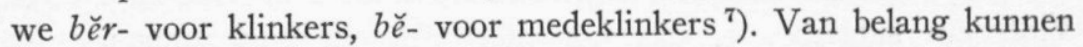
ook zijn dialektverschillen als bv. in het Lampong ${ }^{8}$ ), waar in het dialekt van Pabijan de combinatie ar a.h.w. twee syllaben vormt : sardain wordt gesproken sarědan், ,de vokalische natuur der trillers is wel de verklaring van dit verschijnsel"; in het Aboeng wordt een voorlaatste

1) Van der Tuuk,Tobasche Sprąakikunst, p. 86. Men zie thans ook de opmerking van Goris, Beknopt Sasaksch-Nederlandsch Woordenboek (1939), p. 338, sub 3 .

2) Zie bv. Brandstetter, Die Lauterscheinungen..., (Brandstetter-Blagden, Essay IV), § $57 \mathrm{I}$.

3) Gerth van Wijk, Spraakleer der Maleische Taal, § 19.

4) Schwarz-Adriani, Hoofdstukken uit de Spraakkunst van het Tontemboansch, p. 35 .

5) Zie bv. Beech-Fokker, Tidong Dialects, p. 108.

6) Jonker, Biman. Spr., p. 15.

7) Goris, o.c., p. 44.

8) Van der Tuuk, Het L. en zijn tongvallen, TBG. 18 (1871), p. 126, 132 vlg.

D1. 101. 
lettergreep op ar of arĕ voor cons. door $i$ vertegenwoordigd: sidan, en zo miga tegenover marga; maar ook ibah tgr. p. rěbah. Aan een meer definitief onderzoek van de $-r+$ cons.-woorden zal derhalve een zo nauwkeurig mogelijke vaststelling van de juiste waarde van „de $r$ " in zo veel mogelijk Indon. talen en dialekten en volgens de meest moderne en ter zake geëigende methoden moeten voorafgaan. Helaas is hier nog zeer weinig gedaan.

Leerzaam zijn in dit verband bijvoorbeeld de door Wulff gemaakte opmerkingen over de uitspraak van het Maleis in Perak ${ }^{\mathbf{1}}$ ). Voor consonantische Anlaut valt daar, zegt hij, de $r$ in de praefixen bĕr-, perr-, těr $r$ - uit ${ }^{2}$ ). De $r$ komt consonantisch, gevormd ,in der zäpfchengegend", voor, „offen wie das dänische und bei dem ich nie mitschwingen des zäpfchens beobachtet habe”, en wel vóór vocalen, en in een beperkt aantal woorden als harga, harta ,und in einer kleinen

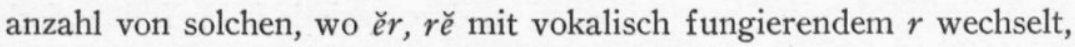
das auch im allgemeinen hinterzungen- $r$ ist” ${ }^{3}$ ). „Auf $r$ auslautende schlußsilben sind... umgewandelt: ar und or $(u r)$ in einen tiefen, offenen, ungespannten $a$-laut.... děñå für děnar ... etc.” $\left.{ }^{4}\right)$. Eigentümlich ist das verhältnis bei älterem $\breve{e r}+$ konsonant (dahin gehören natürlich nicht die mit präfixen $b \breve{e r}$-, pěr $r$-, těr $r$-gebildeten formen, da ihr $r$ geschwunden ist); in der transkription werden solche wörter zum teil oft oder meistens mit $\breve{e r e ̆ ~ g e s c h r i e b e n . ~ I n ~ e i n i g e n ~ h o ̈ r t ~ m a n ~}$ hier bald vor, bald hinter dem $r$ einen schwachen $\breve{e}$-vokal, der einen etwas helleren klang hat, als $\breve{e}$ es in anderen umgebungen zu haben pflegt, zuweilen wohl auch, besonders wenn mehr als eine silbe folgt, blo $B$ ein silbisches $r$, das normalerweise ein hinterzungen- $r$ ist. Hierher gehören sĕrta, sěrba, děrma, kĕrna, pĕrsi, dĕrham, pĕrwara, pĕrstua, pĕrbukala (= purbakala), alles lehnwörter und größtenteils solche, die ich nur als der literatursprache angehörig kenne; ebenso aber die echt malayischen sĕrdan und bĕrnaì. Der wechsel zwischen $\breve{e} r$ und $r \check{e}$ ist ganz willkürlich, und ich hatte mehrfach beweise dafür, $\mathrm{da} ß$ der munshi ${ }^{5}$ ) einen unterschied zwischen sěrba und srěba überhaupt nicht auffassen konnte, obgleich er mir sehr ohrenfällig war; in sčrba-sĕrbi hörte ich ihn mehrfach ganz deutlich sĕrba-srěbi sprechen. In weitaus den meisten fällen ist aber $\breve{r}$, $\breve{e r e ̆ ~ i n ~ d i e s e r ~}$ stellung im hiesigen dialekt anders entwickelt; ich habe von dieser

1) K. Wulff, Beobachtungen über die Aussprache des Malayischen im Sultanat Perak, Acta Orientalia, dl. 4 (1926), pp. 257 vlgg.
2) p. 262.
3) p. 279.
4) p. 289.

5) De Maleier met wie Wulff samenwerkte, zie p. 258. 
art folgende wörter aufgezeichnet: kĕrja, pĕrnah, kĕrbau, chĕrcha, chĕrmat, chĕrmin (tĕ-)kĕrlap, tĕrkam, pĕrdah, tĕrbain, jĕrba, tĕrjun, bĕrsin, bĕrtis, bĕrkat, kĕrtas, mĕryam, murka, měrgástua (so betont), sěriat, sěpěrti; zum teil sind dies wörter, die ich mehrfach oder oft und von verschiedenen sprechern hörte, und es befinden sich unter ihnen neben solchen malayischen ursprungs auch lehnwörter aus dem indischen und arabischen. In der gewöhnlichsten aussprache ist zwischen dem anlautenden konsonanten und dem $r$ kein vokal hörbar, und auf das $r$ folgt ein vokal von normaler länge, aber ziemlich unklarem klang, dessen bestimmung ziemliche schwierigkeiten machte. Er klingt zunächst ähnlich einem å-laut, geschlossener (höher) als der aus -au entstandene, gerundet wie dieser, aber nur ziemlich schwach". Na een meer gedetailleerde beschrijving van de klank: „Bezeichnet man nun diesen laut mit å, so ergibt sich also: krạ̊ạa, kråbạ, tråjụn... Diese aussprache ist aber nicht alleinherrschend: statt des $a ̊ a$ kann, bei den meisten wenigstens, ein wesentlich kürzerer laut eintreten, der mit dem gewöhnlichen $\breve{e}$ in seiner deutlichsten aussprache ziemlich identisch zu sein scheint und vielleicht mit voller stimme artikuliert wird; also etwa krějạ, krěbå, trěbaì usw.... Einige wörter weichen ab: neben mråyam steht mĕryam, neben sprậti spěrti ...; ferner hörte ich sěpĕrti ... mit dem schwachen, helleren $\breve{e}$-vokal nach $\S 40$ vor dem $r$ oder mit silbischem $r$. Dasselbe habe ich gelegentlich auch in einigen anderen gehört (těrbain, tĕrkam, chĕrcha u.a.), kann aber annehmen, daß sie bloß beim lesen gebrauchte formen der schriftsprache sind"1). Van belang is het ook op te merken of de $r$ al of niet assimileert ${ }^{2}$ ).

Het is bij deze - $r$-woorden van belang op de lotgevallen der leenwoorden te letten. Reeds het Oud-Javaans kent vele woorden, die voor ons van nut zijn. Enerzijds zijn er verscheidene tientallen Sanskrit woorden die een praeconsonantische $r$ in Inlaut bevatten: arka, argha, arcana, arcāa, arṇava, ìrșyā, ūrṇā, ūrmi, karkața, karṇa, karma, kìrṇa, kīrti, garjïta, ghūrṇita, carcā, carma, cūrṇa, tarka, tīrtha, tiryak, darpa, durga, durdura, durbala, dharma, dhärya, parva, pārśva, pūrṇa, marma, mārga, varna, varșa, vīrya, sarpa, svarga, harșa, en andere woorden. Anderzijds zijn er ook vormen mèt deze klankcombinatie ontstaan uit Sanskrit woorden erzonder, bv. arga

1) pp. 297-299. - Over $r$ of $l+$ cons.: $r \breve{e}$ of $l \breve{e}+$ cons. zie men bv. ook nog Barth, Boesangsch-Nederl. Wdb. (1910), p. XV.

2) Zie Brandstetter, Lauterscheinungen, § 268. 
$<$ agra, gar $(d) d h a<$ grdhra, darta $<$ dṛta, darya $<$ hṛdaya, durśila $<$ duhsisila, parc(c)aya < pratyaya, e.a. voorts ard(h)ana $<$ ärādhana, zorrsita (wūrșita), e.a., waar dus metathesis en andere verschijnselen, maar geen z.g. epenthesis optreden. Hieruit blijkt voldoende, dat de combinatie $-r+$ cons.- geduld wordt. Ook van $-l+$ cons.- zijn voorbeelden te vinden in leenwoorden als gulma, talpa, tulya, sulka, e.a. Ook onder de woorden die in latere eeuwen uit andere talen in het Javaans werden opgenomen zijn er die deze combinatie hebben en behouden; uit het Arabisch $^{1}$ ) bv. : dabbatul-arli $<{ }^{\circ}$ arḍ, burhan, hurmat, kurban, terwijl berrkat zelfs $<$ barakat is; uit het Perzisch: kurma, sěrban; uit het Nederlands: arnal $<$ haarnaald, arsitèg $<$ architect, artikel, barber $<$ rhabarber, barlè $<$ Berlijns, burdir $<$ geborduurd, dërbus $<$ donderbus, garninson $<$ garnizoen, gorḍ̀n $<{\left.\left.\text { gardijn, } \text { jurnalis }^{2}\right)<\text { journalist, } \text { karcis }^{2}\right)<\text { kaartje, kerkop }<}_{<}$ kerkhof, kĕrnèt < kornet, měrgul ,vergulden”, mĕrnis „vernissen”, perrlop < verlof en andere; ook hier zijn er verscheiden gevallen, waarin door klankuitval, metathesis etc. de combinatie ontstaan is: arbèi $<$ aardbei, barléjan, bĕrduwin < brandewijnn, bĕrgade < brigade, dërmolen $<$ draaimolen, èrḍinĕs $<$ herendienst, gĕrnat, gurnat $<$ granaat, kĕrbin „karabijn”, kursut $<$ kruishout, marsosé $<$ marechaussee, parnèl $<$ flanel, pĕrminil $<$ crimineel, etc. $; \mathrm{ik}$ herinner nog aan leenwoorden uit andere talen die we in het NieuwJavaans vinden, bv, darma, durbiksa, durgama, garḍu, garpu, martèl, pĕrdika, e.a., terwijl ook hier de combinatie is ontstaan in woorden, waarin een $r$ in andere positie voorkwam, bv. běrdañga $<$ skt. mridanga, bĕrtya < skt. bhrtya, darbé < skt. dravya-, jĕrbasa $<$ juru basa, jěrtulis, juru tulis, durnadur, gurnadur ,gouverneur”, kirda $<$ skt. krị̄āa, pĕrkara < skt. prakāra, pěrlaya < skt. pralaya.

Bleef dus ook de combinatie $-r+$ cons.- in menig vreemd woord bewaard, daarnaast staan vele die, in de ontlenende taal zonder $r$, in het Javaans de combinatie wel vertonen: arpokat $<$ ned. advocaat, bartis $<$ batist, bĕrduli, pĕrduli ${ }^{3}$ ) (naast mal. pĕduli), bĕrgasi $<$ bagage, irsaña < ojav. eșānya < skt. aiśān̄̄ ,noordoost", perkansi

1) Vgl. de lijst van A. W. T. Juynboll, ... Jav. en Sund. woorden uit het Arab. of het Perz. ..., Bijdragen Kon. Inst. Congres-nr., T. en L. 1883, pp. 25 vlgg.

2) Ter wille van de uniformiteit handhaaf ik deze spelling ook bij dergelijke woorden.

3) Van de eigennnaam Përtimah, Pratimah $<$ Fațimah en pĕrduli $<$ ar fadiuli- merkte ook A. W. T. Juynboll, o.c., p. 31 de ,ingevoegde $r$ " uitdrukkelijk en afzonderlijk op. 
$<$ vacantie, pĕrmili < familie, e.a. Merkwaardig is de dubbele vertegenwoordiging van bhujainga ${ }^{1}$ ): boejanga, pujainga (literatuurtaal en verouderd) is de ,kenner en officiële beoefenaar der literatuur" : berrjainga ,de dorpswichelaar, deskundige t.a.v. goede en slechte dagen etc.", epenthesis ontstaan in ,lagere kringen".

Ook in andere IN. talen behoort tot de woorden met deze klankcombinatie een belangrijk contingent leenwoorden, bv. in het Sasaks $\left.^{2}\right)$ : arloji, arta, arwah, bĕrgas, bĕrkat, bĕrnes, darma, gĕrdu, kartu, kĕrtas, korma, margi, mĕrta, pĕrlak, sĕrban, sĕrbet, sŏrga; ook hier is de combinatie ontstaan door metathesis etc. : jĕrnat $<$ ned. granat, lurga, vulg. voor lugra $<\ldots$ skt. anugraha, ook nurga, e.a., ook arpat $<\ldots$ ar. 'arafāt. „Epenthesis” is mij daarbij echter niet opgevallen. In het Maleis daarentegen zijn er echter, naast firman (pĕrman), marga, martil etc. en naast woorden als bĕrma $<$ skt. brahmā, gĕrda $<$ skt. garuḍa ${ }^{3}$ ), kornil $<$ eng. colonel, kurnia $<$ kärunya etc., (jĕrki $<$ rizq), pĕrgat $<$ ned. fregat e.a., ook gevallen van ,epenthesis": bĕrduri (= bĕduri, baiduri $)<$ skt. vaiḍūrya ${ }^{3}$ ), (bĕrniaga < skt. vāṇijya), karkus naast kakus < ned. kakhuis, karpus $<$ port. capuz of ned. ka(r)poets (z. ben.), pĕrmili $<$ ned. familie, sĕrpa $<$ skt. śapa, tĕrjalli $<$ arab. tajallī, tĕrmasa $<$ ar.-p. tamāšā ; tĕrzuclu < port. coêlho; ik wijs ook nog op een woord als kunarpa naast kunapa $<$ skt. kunapa; pĕrduli is ook hier een neven-

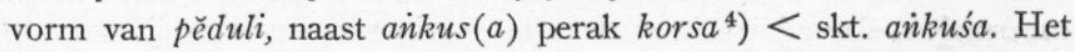
Soendaas - althans voorzover het in woordenboeken is opgetekend - kent relatief weinig woorden met deze combinatie in het midden; daarvan zijn er verscheidene leenwoorden: arpus $<$ ned. harpuis, bĕrkah, bordel $<$ ned. borduren, kĕrtas; soms vermeldt Coolsma ${ }^{5}$ ) een dubbele vorm: pĕrsen $=$ 't meer gebr. pĕrĕsen $<$ ned. present, sĕrěbad $=$ 't meer gebr. sarbad (ook sĕrbad) $<$ ar. šarbat, těrěka meer gebr. dan tĕrka < skt. tarka, naast sarsan ook saréyan $<$ ned. sergeant; enkele metathesis-gevallen etc. : nurgaha $<$ nugraha, pĕrbu $<$ prabu; narpati ,heer, vorst” behoeft niet, als Coolsma wil, < skt. narapati-, doch kan ook uit het in het OJav. voorkomende skt.

1) Waarover Bijdr. Kon. Inst. 89, p. 253 vlg.

2) De betekenissen der woorden gelieve men desgewenst na te slaan in Goris, Beknopt Sas.-Nederl. Wdb., Singaradja 1939. In dit werk, dat de herkomst van vreemde woorden aangeeft, is dit een enkele maal verzuimd, zo bv. s.v. kartoe.

3) Hier en elders wordt de ontleningsgeschiedenis verkort aangeduid.

4) Wulff, A.O. 4, p. 288.

5) Coolsma, Soendaneesch-Hollandsch Woordenboek, s.v. 
urpati-; voorts perdio < pro deo, surti < skt. śruti, etc. Zeer zelden is in het mij bekende Soendaas de ,epenthesis”: martabak ,'n bep. gebak" < ar. mutabbaq, vermoedelijk onder invloed van andere Arab. woorden met een neiging tot inverse analogie, mal. murtabat wordt vaak i.p.v. martabat gehoord; vermenging met dit laatste woord, dat in „overdrachtelijke” zin voorkomt : „rang”, wegens de lagen (,trapjes") van het gebak lijkt me niet aannemelijk; karpus, kĕrěpus, kàn een voorbeeld zijn, maar het Nederlands heeft karpoets naast kapoets; naast paduli ook hier pěrduli.

In het Toba-Bataks, dat vele $-r+$ cons.-woorden kent, heb ik geen ontwikkeling van $r$ in een leenwoord kunnen constateren; in het Karo is bv. sĕrka ,spinnewiel” uiteindelijk uit skt. cakra ontleend. Het Atjehs heeft, gelijk bekend, een uitgesproken voorkeur voor -eureu - in het ons bezighoudende geval: ned. barkas $>$ beureugaïh, arab. burqu' $>$ beureughò', ned. briljant $>$ beureulian, eng. German $>$ jeureuman $^{1}$ ), skt. kārya $>$ keureuja $^{1}$ ) etc.; een woord als terjali komt echter ook hier voor.

Het is duidelijk, dat hier bij deze leenwoorden an een oud IN. infix $r$ niet is te denken. Een verklaring kan ten dele liggen in het verschijnsel der zg. inverse analogie; wanneer de sprekers van de taal zich bewust zijn dat zij op bepaalde punten, bv. bij overgenomen vreemde woorden, een minder correcte uitspraak hebben, gebeurt het meermalen, dat zij trachten deze te corrigeren, en daarbij dan wel hun doel voorbijschieten door ook te onpas de in hun ogen juiste uitspraak te bezigen. Zo hoort men bij ons vaak Sédan en St. Dénis voor fr. Sedan en St. Denis. En zo zegt de patoisant in de Ardennen, die weet dat hij vaak een fr. $r$ weglaat, erglatí i.p.v. églantier $\left.{ }^{2}\right)$, en zo wordt bij eigen woorden naast lard $>l \bar{a} d$ op Engels gebied $l \bar{a} f$ $($ laugh $\left.)>\operatorname{larf}^{3}\right)$. Een teloor gaan van $r$ voor cons., gelijk we zagen op Indonesisch gebied bekend, is bv. in het Maleis bij leenwoorden nu en dan te constateren: cěmět $i$ teruggaand op skt. carmayaști, kĕtika naast kĕrtika < skt. krttikā (hierbij is echter invloed van kĕtika $<$ skt. ghațikā in het spel $\left.{ }^{4}\right)$ ), (min.) pětugal naast pěrtugal $<$ Portugal, bělian $=$ bĕrlian $<$ brilliant .

Het kan ook zijn, dat de vorm zijn $r$ mede te danken heeft aan een adaptatie aan een in de ontlenende taal bekende vormkategorie

1) $j=d j$.

2) Zie Ch. Bruneau, Étude phon. des patois d'Ardenne, Diss. Parijs 1913, § 212.

3) W. Horn, Untersuchungen zur neuenglischen Lautgeschichte (1905), p. 61.

4) Zie Opmerkingen over woordvorming, Bijdr. dl. 100, p. 162. 
of woordtype. Dit is stellig het geval bij b̆̌ $(r)$ niaga, waarin men een $b \breve{e r}$-vorm heeft gevoeld, wat aanleiding heeft gegeven tot het ontstaan van perrniagaan, en in het Minangkabaus zelfs van tiago, tiagan. Zo kunnen ook de praefixen pĕr-, těr- enz. zich hebben doen gelden. Maar hiermee zijn de verklaringsmogelijkheden nog niet uitgeput.

In andere talen is het verschijnsel vaak wèlbekend. „In vielen Mundarten schwindet $r$ vor gewissen Konsonanten wenigstens, so daß der Mundartsprechende das Gefühl bekommt, daß er bei schriftdeutscher Aussprache haüfig ein $r$ vor Konsonant einsetzen muß" ${ }^{1}$ ). Zo vindt men op verschillende plaatsen van het Duitse taalgebied $\left.{ }^{2}\right)$ : estermiren $<$ aestimieren, fermost $<$ famos, karnalje $<$ fr. canaille, opsternat $<$ obstinat, karneil $<$ fr. can $(n)$ elle, karmille $<$ kamille, unerform $<$ uniform e.a.; in de Pfalz komt voor degrediren, wat over dekartieren $<$ fr. décatir. De werking van de analogie kan zich doen gevoelen: naar kartusche, Karthäuser, karton etc. vormt het volk karnalje, kartholisch, kartun etc. ${ }^{3}$ ). Ook in het Nederlands ,houden we er van om in Franse woorden een consonant in te voegen in de syllabe voor het accent", en wel een liquida $\left.{ }^{4}\right)$; bv. fĕrsoendelijk, kĕrstanje, mnd. gavěrlote, karnalje, karsuifel (Hooft), kampĕrnoelie, verkansie $\left.{ }^{5}\right)$, věrsier $<$ vizier, vĕrnijn(ig) (Coolen) $\left.{ }^{6}\right)$, als kind sprak ik zelf van fĕrnielje : vanille. Ook in Nederlandse dialekten in vreemde woorden ${ }^{7}$ ): in het Gronings met metathesis ${ }^{8}$ ) gĕrniet $<$ graniet, kĕrdiet $<$ krediet, kĕrpoairn $<$ krĕperen, andere: kĕrnel (bij Hooft kornel, deze vorm ook > IN. kornèl?) = kolonel, pervoart ,ophef, drukte" $<$ fr. pouvoir $\left(\right.$ ?) $\left.{ }^{9}\right)$, in het dialekt van W.Voorne: fĕrlies : valies, fĕrnien : venïn, fĕrsoen : fatsoen, e.a. $\left.{ }^{10}\right)$, in

1) W. Horn, Zur Iautlehre der franz. Lehn- u. Fremdwörter im Deutschen, Zs. f. franz. Spr. u. Litt. 22 I (1900), p. 64.

2) Vgl. ook L. Jutz, Die Alemannischen Mundarten, Halle (S.) 1931, p. 264.

3) O. Weise, Unsere Mundarten ${ }^{3}$, p. 118.

4) Zo Salverda de Grave, Het individuele element bij het ontlenen van vreemde woorden, Hand. 2e Ned. Philologen-Congres 1900, p. 95.

5) W. de Vries, Iets over woordvorming, Progr. Gem. Gymn. Groningen 1920-21 I, p. 8 ziet in verkansie kruising uit vacantie en verlof. Invloed van de vele ver-woorden schijnt mij zeker aanwezig. Op p. 33 zegt dezelfde auteur: „na verzwakking der eerste vocaal tot $ə$ kon men de beginsyllabe van vacantie, visite licht met ver- verwarren".

${ }^{6}$ ) Ik dank enkele dezer voorbeelden aan Prof. Dr. G. Royen.

7) Een standaard-voorbeeld voor $-l$ - is het verbreide kwispeldoor $<$ kwispedoor $<$ port. cuspidor $<$ lat. *consputorium.

s) Metathesis ook in de volksmond: krokodil $>$ kurkedil.

9) K. ter Laan, N. Groninger Wdb. (1929), s.v.

10) Meer bij Van Weel, Dial. v. W.-Voorne, Diss. Amsterdam, 1904, p. 42. 
dat van Maastricht met metathesis pĕrsessie < processie; in dat van Hasselt (België) in voortonige syllabe in fr. côtelette, colonnade, échalotte $>$ šàrlot e.a., terwijl ook de ,omzetting” in vreemde woorden bekend is sàkĕrsté < sakristij e.a. ${ }^{1}$ ); ook elders in het Vlaams vinden we onze $r$, bv. pesterlencie : pestilentie; bij sommigen zullen blending en „,volksetymologische” invloeden hebben gewerkt: karbies $<$ fr. cabas $(X$ valies?), kortelas $<$ fr. coutelas $(X$ kort ?, of kortjan, 'n zakmes) ${ }^{2}$ ). Vgl. ook z.afr. fluweel $>$ verweel. Dezelfde moeilijkheid, waarvoor we bij IN. woorden enige malen staan, nl. of niet reeds in de taal waaruit ontleend werd de ,epenthesis” aanwezig was (kornel, karpoets is ook Nederlands), vinden we hier: korporaal gaat terug op fr. caporal, waarnaast ook $(X$ corps) corporal. Ik herinner ook aan ned. jaloers $<$ fr. jalous, jaloux, floers $<$ ofr. velous, nfr. velours, du. dial. firluršt ${ }^{3}$ ), eng. lark tgr. angs. lac ,play", eng. dial. clart, clort ,a clot or spot", waar de $r$ op een andere plaats in het woord voorkomt. Franse voorbeelden: arqueduc : aqueduc ( + arc, „parce que presque tous les aqueducs sont élevés sur des arcs"), corniculata $(<$ caniculata $<$ calyculata, lat., colchium autumnale $\times$ corneille) ,,herfsttijloos”, waarbij dus vervormende invloed van andere woorden is uitgegaan, wat ook het geval is met de peersoort die in het Italj. bergamotta, in het Fr. bergamote heet en waarvan de naam op turks beg-armâdé ,here-peer" schijnt terug te gaan, doch later te zijn verbonden met die van de stad Bergamo; charlotte naast échalotte is uit ascalonia „ui uit Ascalon”. In het Engels heeft lat. latrocinium zich tot larceny ontwikkeld; uit blending (blamed + darned) wordt verklaard blarmed in Engels slang, carnardine is ,incorrect for carnadine” enz. In het Roemeens wordt advocaat wel arvocat $^{4}$ ) In het Portugees vinden we marmelada (vd. in Fr., Eng., Ned. etc.), afgeleid van marmelo „kweepeer” uit lat. (uit Gr.) melimèlum „honigappel”; middeleeuws lat. scarlatum, fr. écarlat is

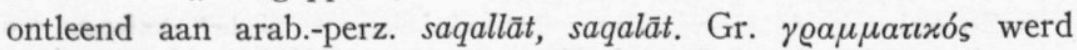
armeens granarikos, $\mu a ́ x \varepsilon \lambda \lambda \alpha$,schop, spade" $>$ markel $^{5}$ ).

Soms zijn er zeer duidelijk dissimilatieverschijnselen waar te

1) Grootaers en Grauls, Klankleer van het Hasselts dialekt, 1930, p. 108.

2) Zie Van der Meer, Hist. Gramm. d. Niederl. Spr. I (1927), § 260.

3) „Nach firliarän”, volgens P. Schild, Brienzer Mundart I, Diss. Göttingen 1891, p. 44.

4) Zie Sandru, in Rosetti, Bulletin linguistique 5, p. 141; vgl. ook 4, p. 131.

5) Men zie ook de interessante gegevens bij E. Mayser, Grammatik der griech. Papyri aus der Ptolemäerzeit (1906), I, § 40. 
nemen: fr. dial. v. Parijs sornambule $<$ somnambule ${ }^{1}$ ); andersom bv. sp. fr. $\operatorname{fanfar}(r)$ on $<$ ar. farfär , lat. cancer ,kreeft; kanker” tgr. gr. xa@xivos ,,id.”, skt. karkata- „kreeft”; met „,verspringing”(?) Gronings dial. karlswòddel $=$ kalmuswortel.

Ook in niet-ontleende woorden komt deze $r$-epenthesis voor, hoewel ik er minder gegevens over heb: „Umgekehrt findet man zuweilen $r$, wo es etymologisch unberechtigt zu sein scheint. Neben ahd. $\ddot{e} d o$, odo : ërtho, ërd(h)o; neben widar: wirthar, wirdar; neben wëdar vereinzelt wërdar. Nirgends hat das $r$ bestand" ${ }^{2}$ ). Dialektisch ${ }^{3}$ ) is bv. lärwarmå i.p.v. Lebemann. In de Vogezen vindt men ,assez frequemment intercalation d'un $r^{\prime \prime}{ }^{4}$ ); in andere Franse dialekten ook wel, bv. in Auvergne, hoewel zelden, paerpaelju $<$ papilionem ${ }^{5}$ ). In het Italj. zet farfalla ,vlinder" lat. papilio voort. In het Engels is arter $<$ after (via arfter), darter $<$ daughter, sarser $<$ saucer etc., en in andere woorden, ook individueel, niet onbekend; dentale consonanten, vooral wanneer een andere $r$ in de volgende syllabe staat (stond), hebben een bevorderende invloed ${ }^{6}$ ). In het Nederl., dial. en in de volksmond, hoort men wel kĕrnīn, i.p.v. konijn, dat al lang volkomen ingeburgerd is; ook scharminkel heeft „een jongere $r$,, mnl. is scheminkel. Op Germaans gebied zijn zeer vroege voorbeelden te constateren ${ }^{7}$ ).

Op Indonesisch terrein vinden we binnen dezelfde taal meermalen wisseling van $r$ en nul ${ }^{8}$ ). „De zware lettergreep, zoo zij de voorlaatste is, wordt vaak door een doorklinker $(l, r, s)$, die er een anderen sluiter verdringt, gesloten; waarbij op te merken is, dat de $s$ meestal vóór geen anderen medeklinker dan de $t$ komt, bv. hurtut naast huttut, ....orgos (M.) $=$ ogos, bargot (M.) $=$ bagot, turbun $=$ tubun...” $\left.{ }^{9}\right)$. „Vandaar ook portáng naast botáng, porngís naast bongis, borhá naast bohá..." ${ }^{10}$ ), waaruit blijkt, dat ,in de ligtste

1) H. Bauche, Le langage populaire, p. 250.

2) Wilmanns, Deutsche Grammatik I (1893), p. 96, § 113 Anm. 1.

3) A. Lang, Die Zschorlauer Mundart, Diss. Leipzig 1906, p. 22.

4) O. Bloch, Les parlers des Vosges méridionales, p. 147.

5) A. Dauzat, Études liguistiques sur la Basse Auvergne, Fac. d. Lettres Paris 1897 , p. 54.

6) W. Franz, Die Dialektsprache bei Ch. Dickens, Engl. Studien 12 (1889), p. 204.

7) Weinhold, Alemanische Grammatik, § 197.

8) Gevallen als atj. perrlan: mal. tělan, tbat. dorguk: mal. tĕguk laat ik buiten beschouwing.

9) Van der Tuuk, Tobasche Spraakkunst I (1864), p. 55, § 27 I.

10) Ibidem, p. 58, § 28 II. 
lettergreep” ook de medeklinkers ,als sluiter onzeker kunnen zijn”. Parallel met deze verschijnselen in het Bataks (vgl. ook pargut : pagut „pikken”) zijn de volgende in het Maleis: cěrcak "slightly pock-pitted" naast cĕcak, cĕrgas, cĕrĕgas naast cĕgas „stoer”, cĕrkau naast cčkau ,grijpen naar”, girlap naast gilap ,schitterend", jĕrlok naast jělok (Djoh.), in Ked. jĕrĕlok „diepe holte”, kĕrbat naast kĕbat ,stevig vastbinden”, kĕrlip naast kělip ,flikkeren”, pĕrcah naast pĕcah „e.s.v. schip”, těrkup naast těkup ,onder de holle hand etc. bedekken, pakken”, e.a., těrkukur naast těkukur ,tortelduif" is zeker een onomatopee. Voorts běsut : bĕrsut ,'n plotseling zuur of geërgerd gezicht”; bĕrtih : bětih ,ongebolsterde rijst, met een knappend geluid (waarbij geweervuur vergeleken wordt) in de pan geroost", denke men ook aan Palembang: Perrlembang. In het Sasak is pĕrlak een nevenvorm van pĕlak ,verschillend”, purlas „dof (van de ogen)" van pula', curlek is dial. voor culek. In deze taal schijnt speciaal $-n$ - met $-r n$ - te wisselen: kĕpunes $: k e ̆ p u r n e^{s}$ „bosduif" ${ }^{1}$ ), maar overigens heeft $b \breve{e}$ - als formatief element soms de nevenvorm bĕr- : bĕrson ,op het hoofd dragen” ${ }^{2}$ ), naast těson. Ook Javaanse voorbeelden zijn er: kěpek : kerpek „esv. mand of koffer”, sĕsĕg „dicht opeen”: (lit.) sěrsĕg, cĕrcělan naast cěcĕl „dicht op elkaar schuiven, tussen schuiven"; vgl. ook jav. dipěrgogokaké naast mbĕgogok „stil blijven zitten”; dial. pĕrkĕněnian „warm lopen (in 'n gesprek) naast běkĕněn, e.a.

Er zijn gevallen waarin, in etymologisch identieke woorden, de ene taal geen, de andere wel deze $r$ heeft, bv.: jav. b̌̆ni $i$, wěni $i$,nacht”: soend. wĕni, nias bonii, mori wonii, mak. banii, boeg. wänni, etc., in Melan. en Polyn. talen ook in deze vorm bekend (Fidji mborii, Sa'a poni etc.), maar tbat. borinin; tbat. gulin ,gerold”, mal. gulin ,rolkussen”, jav. id., ngday. găguliin „rollen” etc., maar in het Lampongs van Kroë gurliin „(voort)rollen” ${ }^{3}$ ); naast tag. pasan, mak. pisāin „dragen”, mal. pěsan, sas. pěsan ,gelasten”: k.bat. pěrsan, tbat. porsan „op de schouder dragen”, porsanon ,last”; naast mal. těluk „baai, zeeboezem”, ngday. telok „baai, bocht”: tbat. torluk; naast mak. bise „korte roeiriem”, ngday. besei: tbat. borsi; sas. kěsik „zand” : mal. etc. kĕrsik; in het Tarakan-dialekt van het Tidong is ",rondzwalken" mabas, in dat van Bolongan marbas ${ }^{4}$ ); tegenover mori

1) Zie voorts Goris, Beknopt Sasaksch-Nederlandsch Woordenboek, p. 241 II sub 6.

2) Goris, o.c., p. 44.

3) Helfrich, in Verh. Bat. Gen. 45, p. 19.

4) Beech, The Tidong Dialects of Borneo, pp. 38, 58, 72. 
bose „roeispaan”, soend. bosèh „pagaai” staat tbat. borsi, tag. bagsaj $(g<r)$; mal. cabut : t.bat. sarbut ,(uit)trekken”. Naast pijak ,treden op” in Mal. NgD. etc. heeft het K.Bat. perrjak ${ }^{\mathbf{1}}$ ), doch hier is geen volledige identiteit aanwezig. Nog minder bewijskracht hebben vergelijkingen als ojav. dělin ,zien”, bis. hilï „nauwlettend zien naar”, boeg. jĕlliin „lonken” : mal. kĕrlin, cĕrlïn „,zijdelings aanzien” naast jĕlin, tbat. borhat ,een reis aanvangen” : aikkat „weglopen”, al kan

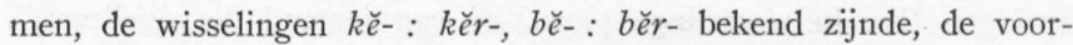
beelden in aanmerking nemen. Zo vindt men bv. ook naast mal.

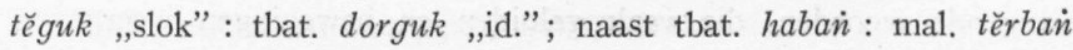
„vliegen”, en andere meer.

Het verdient te worden opgemerkt, dat er ook voorbeelden zijn van hetzelfde verschijnsel met $l^{2}$ ): naast jav. mal. soend. gěmuk „,vet, smeer" heeft het TBat. golmok ,dik zijn”, naast jav. wětĕn, soend. bötön ,buik” etc. : t.bat. boltok ${ }^{3}$ ) ; naast ngday. tikas wellicht: t.bat. tolhas ,,aankomen" ${ }^{4}$ ).

Woorden met ,inwendige $l$ " zijn bv. in het Karo-Bataks niet zelden: selkut, selpat, seldem etc.; t.bat. talmis ,vet”.

Afzonderlijke vermelding verdienen ook de meer ingewikkelde gevallen als ,kies" ${ }^{5}$ ) — als meer woorden voor lichaamsdelen 'n grote variëteit van vormen vertonende - njav. bam $<$ bahěm, lamp. bihom, nias boha, (tag. bagain, hova vazană. etc.) naast daïri barham, soend. carèham, mal. gĕrham en gĕraham; karbau: saw. kebau, jav. soend. kĕbo, mal. kěrbau, tbat. horbo, tag. kalabao, soemb. karămboa, bol.-mong. karombou, ponos. kahambou, maar tomb. kĕrwou; ojav. bakiti „mier”, njav. (litt.) brakiți en blěkiți, ook bělkiti ${ }^{6}$ ). Ook dient er gewezen te worden op varianten ${ }^{7}$ ) als mal. pĕrkakas, pěkakas, běkakas ,gereedschap enz.”, těrbin : těrubin ,'n visfuik”, těrbok :

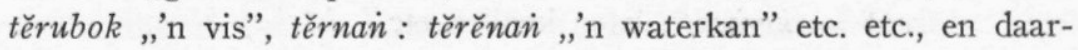
naast ook těrbai்: těrěban ,vliegen”, těrbis : těrěbis „wegglijden”,

1) t.bat. torjak.

2) Er zijn echter archipel-talen, die geen $l(r)+$ cons.-verbinding kennen : Jonker, Rottineesche Spraakkunst, $\S 8$, p. 12.

3) Zie Lafeber, Klankleer Nias, p. 31 .

4) Brandstetter, Das Abstraktum, p. 26, verbindt day. tikas, ojav. wěkas met k.bat. tělkas „entladen”, wat m.i. onjuist is, daar tělkas „uitgestort (van sperma)" betekent.

5) Vgl. bv. Brandstetter, Prodromus, s.v.; Dempwolff, Vergl. Lautl. III, p. 19; 57. In het algemeen mijn opmerkingen: Over de toepassing der comp. methode..., Bijdr. Kon. Inst 99, p. 442.

6) Zie Van der Tuuk, KBW. IV, p. 913.

T) Ik ga nu van de spelling uit. 
tĕrbit „opkomen etc.”, tĕrjun : tĕrujun, tĕrajun (dial.) „afspringen” enz. Daarbij is mij opgevallen, dat deze en de andere met těr- aanvangende ,werkwoordelijke grondwoorden" in het Maleis (snelle, plotselinge) bewegingen aanduiden: tĕrban ,instorten”, těrjak ,plotseling opvliegen( van een kuiken)", těrkam ,opspringen om te pakken (bv, van 'n leeuw, kat etc.)", terrkup ,,iets vangen onder een hol voorwerp (bvi. een vlieg onder z'n hand)", těrpa ,impulsief voorwaarts springen (bv. in plotselinge toorn, of van iemand die duelleert)", těrpul ,in stralen te voorschijn komen”. Bij de met gĕrě- etc. aanvangende woorden, die vaak geluiden en bewegingen weergeven, vinden we er die als nevenvormen van gĕr-woorden vermeld worden: gĕrěbas $=$ gĕrbas, gĕrěbus = gĕrbus „ritselend etc.”, gěrěmain $=$ gĕrmaì „te berge rijzen” enz., of andersom gĕrdak = gĕrĕdak „ratelend geluid”, gĕrdam = gěrědam ,bonzend”; zo vindt men naast met sĕrĕ- beginnende woorden sĕr-tormen. Vele gĕr-woorden ${ }^{1}$ ) hebben het karakter van onomatopee, Lautbild, klanksymbolische vorm: gĕrbak „een luidruchtige vogelverschrikker”, měngěrbak = měñĕrbah (sĕrbah) „verspreid zijn”, gĕrban ,losuiteenhangend als wanordelijk haar”, gĕrbas ,ritselen”, gĕrdas ,backward jerk or stroke with the thumbnail” (Wilkinson), gĕrdum ,dreunen”, gěrlap „blinken”, gĕrloh „snorken”, gĕrñam „prikkelend gevoel van slapende ledematen”, gĕrñut ,wriemelend”, gĕrsak, gĕrsok ,,een geluid als van voetstappen op nat zand”, gěrsik ,grint”, gěrtak „,schudden”, etc. Men lette verder op woorden als mal. buroì běrkèk, ,de vogel die kèk zegt", in Batav. bĕlěkèk, bĕrlïn naast č̆(m)pěrlin, cĕrlin, pěrlin etc., bĕrsin „niezen”, bĕrtoh (Pin.) „botsen” ${ }^{2}$ ), cĕrbis „slippen”, cĕrcap en cĕrcup „flappen”, cĕrlan,, cěmĕrlan் „flonkeren”, jĕrpak = jĕrĕmpak „plotseling overvallen”, kĕrbok „,borende in (van ratten etc.)”, kĕrcap = kĕracap ,laten knallen etc.”, kĕrkap-kĕrkup „,crunching and munching”, kĕrloh „kreunen, kermen”, měrkah = rěkah „kraken”, pĕrcit ,uitspuiten van water”, pěrcek „spikkel”, pĕrcup ,applaudiseren”, sĕrgap „doen schrikken etc. door een plotselinge slag”, etc. etc. Ook andere Indonesische talen kennen, de een meer, de ander minder, dergelijke woorden: jav. bĕrjog „overvallen” naast blějog, bĕrbah naast brubuh ,neergehakt”, mbĕrsot ,zich uit de voeten maken”, vgl. mbrosot, nḍerrdĕg = drĕḍĕg ,beven”, kěrkèt ${ }^{2}$ „pie-

1) Men vergelijke ook gevallen als tbat. harbaian: mal. gĕrěban் „hoofdpoort".

2) Ik merk op, dat ik dit ber- (parallel met cĕr-, dĕr-, sĕr- enz.) niet voor het praefix houd; zie ook beneden, p. 179. 
pen en kraken”, kĕrkut „knarsen (tanden)”, měrběs = brĕbĕs „(door)sijpelen”, pěrsak ,een zanderig gevoel in de mond hebben”, těrcě $k^{2}$,licht klapperen” naast trěcě $k^{2}$ etc. etc.; in het Sasak maken de indruk tot deze kategorie te behoren: darsot ,uitglijden”, jĕrlam (dial.) „schitteren”, pěrtak „kloppen tegen iets”, terbos „oprisping”, těrpa ${ }^{s}$,neerstrijken (van een vogel)”, těrsin „niezen”, e.a., in het Toba-Batak birsak „spuiten (water)”, bursik „uitgespuwd”, garpas „spartelen (van een stervende kip etc.)”, gordan ,trommel”, gurduk ,wegjagen door te kloppen”, hordit „sidderen”, in het Karo-Batak perrkas „de inslaande bliksem” '), derkuh ,,jammerend van pijn”, cěrkěp ,e.s.v. slagnet”, surpak „,over z'n gehele lichaam beven”, kurtak ,'n klappend geluid maken om een paard aan te zetten"; in het Gajo běrtuh "granaat", kěrkak-kĕrkèk „langs elkaar schuifelen”, kĕrlèn „klanknab. v. 'n rinkelend geluid”; merbuk ,tortelduif”, kertun ,,een tun zeggend bamboe-toestel” ${ }^{2}$ ).

Het schijnt evident, dat in deze soort van woorden de $r$ deel uitmaakt van het ,primitieve”, expressief-effectieve klankbeeld van het woord in z'n geheel ${ }^{3}$ ). Dit wordt nog duidelijker, wanneer we ons herinneren, dat meermalen naast een woord van het type berrjog een langere nevenvorm staat, die klaarblijkelijk deze waarde heeft. Aan de reeds terloops genoemde voorbeelden kan men o.a. nog toevoegen: mal. kĕrlap „flikkeren”, waarnaast kĕměrlap, gěmĕrlap, naast kilap etc., kĕrkut: (kĕrěkut,) kĕděkut „(Ked.) stingy, mean, closefisted”, kčrtok: kĕrotok (gěrĕtok) „houten bel”; kĕrbas : kĕribas „schudden". Het blijkt ook in gevallen als tont. kerker ,een vogelnaam” waarin „de wortelherhaling volkomen is gebleven, ... (met) de bedoeling om het geluid van het dier zoo getrouw mogelijk weer te geven", terwijl anders de eerste $r$ tot hamza geworden zou zijn:

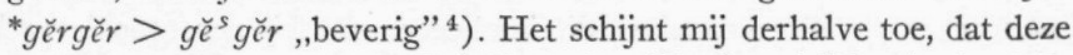
$r$ (althans een $r$ in het schrift!) hier ,dezelfde functie” heeft als -ёrě-, -oro- en dergelijke syllaben in het welbekende woordtype kĕmĕrlap etc. Men spreekt in een aantal gevallen van frequentatief-vormen, $\mathrm{nl}$. wanneer er, zoals in het Javaans wel bekend is, een $r$-loze vorm naast staat: bv. mal. kerrbas ,shaking out; to keep shaking. A freq. of

1) Brandstetter, Blitz und Donner in Ind., in Donum Natal. Schrijnen, p. 169: „Die meisten Ausdrücke für Donner in den IN. Sprachen sind schallnachahmend. Sie enthalten das dumpfe $u$ oder das rollende $r$ oder beide Laute wie sund. gumurudug „donnern”."

2) Beschrijving bij Hazeu, Gajosch-Nederl. Wdb., p. 365.

3) Ik verwijs ook naar Brandstetter, Die prim. Schöpfungen ..., p. 14.

4) Schwarz-Adriani, o.c., p. 30. 


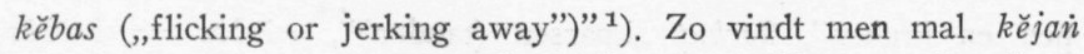
„een been of arm uitstrekken”: kĕrjan ,hetzelfde met plotselinge stoten (als een zwemmende)". Op deze vormen, omtrent welke ik tot een opvatting neig, die van de gangbare afwijkt, hoop ik echter binnen kort, om dit opstel niet te lang te maken, in ander verband terug te komen.

Een voor ons doel interessante groep van woorden zijn nog de driesyllabige van het type jav. mběrgajag, běrièṅèh, die tot enkele betekeniskategorieën behoren: geluiden, ongewone, brutale, eigenzinnige houding, voorkomen, onverzorgdheid, e.d.: mbĕrgajag naast grajag „plassen”, mbĕrgagah „wijdbeens staan”, mbĕrgandan ,z'n zin doordrijven”, mběrganjak „kranig”, mběrnè̀ǹ̀h „hinniken”, diběrkènkè̀n ,poten etc. van 'n geslachte kip zijn uit elkaar gespannen”. Er zijn ook enkele met jĕr-: njĕrbabah „,met gespreide ledematen neervallen”, njerbèbès, "gaan of blijven druipen (van vocht)", měr-: mĕrnianas (en daarnaast met andere vocalen) „grijnzen”, měrkènkè̀n „met de benen wijd uiteen”, en met děr-: dĕrkutu „tortelduif”, ndĕrmèmèl ,zonder ophouden gebeden prevelen etc.", ndĕrmĕměn் „blijven mopperen”, cĕr-: cĕrǹ்̀̀̀̀han „steeds maar grijnzen”, pěr-: naast mĕrkènkèn, bĕrkè̀nkèn (zie boven), bĕkènkèn: (di)pĕrkènkènaké. Er komen ook gevallen voor als patin pĕrkakah ,overal op afstanden van elkaar staan”, patin pěrkètèk ,overal geknetter”, die er het hunne toe bijdragen, dat men deze drielettergrepige uitdrukkingen aanvangende met berr- etc. op één lijn zal stellen met de zo juist behandelde disyllaba, waarmee ze een groep van onomatopoëtische woorden, Lautbilder, klanksymbolische termen vormt, waar binnen analogie en blending op grote schaal werkzaam schijnt te zijn geweest. Ik zou zeer aarzelen de $r$ hier een verstard infix te noemen, zoals Dempwolff e.a. ${ }^{2}$ ), daar dit impliceert, dat hij eens een levend infix geweest is. Om misverstand te vermijden zou ik onder affixen (prae-, suf-, infixen) in Indonesische talen willen verstaan elementen, die in een reeks van woorden buiten het ,grondwoord" voorkomen, het grondwoord uitbreiden, (onder vorming van een eenheid aan het begin, in het midden of aan het eind daarvan optreden), en in de gehele reeks zelfstandig ${ }^{3}$ ) eenzelfde of samenhangende grammatikale of semantische waarde of functie hebben, het gehele woord in een

1) Wilkinson, o.c., p. 569 . Zo ook Klinkert, Wdb. ${ }^{3}$, p. 553 sĕrěbu, freq. van sĕbu.

2) Zie bv. Dempwolff, Vergl. Lautlehre I, p. 45 sub a 3 ; p. 70 sub a 1 etc.

3) Met inbegrip van gevallen, waarin deze waarde door twee of meer affixen wordt gedragen: mal. pĕr-jalan-an. 
bepaalde vorm- of woordsoort-kategorie brengen. Zo noem ik in mal. makan-an -an een affix (suffix), in o.jav.pinuji -in - een affix (infix). Maar daar waar een bepaalde klank slechts sporadisch optreedt, zoals bv. de $p$ in mal. tĕptibar = tětibar ,geitenmelker (e.s.v. vogel)”, of daar waar een klank of klankgroep in een variantenreeks méér optreedt dan in synoniemen, zoals bv. in mal. kěrlip ,flikkering” naast kělip, kĕdip etc., daar waar met sporadisch optreden geen betekenisverschil samengaat, zou ik de term niet willen bezigen. Een dergelijk element kan echter een affix worden, en ook het bestaan van verstarde affixen wil ik geenszins ontkennen. Evenmin ben ik geneigd om in woorden als jav. bĕrnì̀nèh de eerste syllabe te identificeren met bĕr in mal. bĕrkuda, bĕrjĕmur, bĕrcukur, al zal ik niet ontkennen, dat er een historisch verband geweest $\mathrm{k}$ a $\mathrm{n}$ zijn. Maar dat zullen we niet a priori mogen aannemen. De overeenstemming van děr- en jĕr -woor-

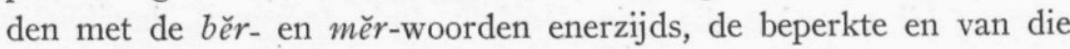
van de Maleise met $b \check{e} r$ - gepraefigeerde woorden etc. afwijkende betekeniskategorie, waartoe al deze uitdrukkingen behoren, het ernevens voorkomen van disyllaba met gelijke aanvang, waar men bĕr- etc. als eerste syllabe van het grondwoord pleegt te beschouwen en niet als praefix, wijzen ook hier m.i., evenals boven bij de $m \breve{e}-+$ nas. woorden er op, dat de genoemde syllaben beter niet als affixen met běr- in mal. bĕrcukur „zich scheren”, bĕrkuda „met een paard” gelijk gesteld mogen worden. En dit parallellisme van de $b \breve{e}$ - etc. $+r$ met de $b \breve{e}-$ etc. + nasaal-vormen ${ }^{1}$ ) steunt het betoog, dat we hier voor ieder hunner afzonderlijk voordroegen. Immers àls we te doen hadden met verstarde affixen, die eens een wel omschreven zelfstandige grammatikaal of semantisch modificerende functie gehad hadden, dan is het toch wel curieus, dat twee affixen (één met $r$ en één met $n$ of $r$ en $n$ alleen) geheel deze zelfde rol hebben gespeeld en beide, zij het verstard, in een groot aantal gevallen bewaard zijn gebleven.

Het is van voldoende bekendheid, dat ook de $r$ in primitieve woorden vaak een zekere klanksymbolische rol speelt, aan de elders gegeven $^{2}$ ) voorbeelden voeg ik toe gevallen als: skt. dardara- ,e.s.v. trommel”, dardura- „kikker; e.s.v. fluit; geluid van pauken”, jharjhara- „e.s.v. trommel”; voorts du. knarren, knurren, knirschen, fr. gratter, craquer, crépiter, hurler, ned. knersen, knarsen, kraken, lat.

1) Zie boven, p. 152 vlg., vgl. bv. jav. mbĕnkayan் „stijf (v. lichaamsdeel)”, mbĕnk(e)rok „ruw (huid)", bĕnciritĕn „schraal (gewas)”.

2) Remarks, pp. 165; 167. Beneden nader. Men zie bv. ook Grammont, Traité de phonétique, p. 392 vlg. 
crepare, crispire, crocire, gingrire, russ. krakati „krassen”, kukorékati

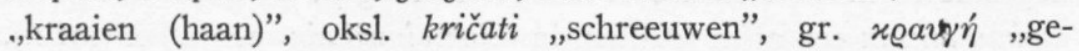
schreeuw", $x \varepsilon \varrho \gamma \nu \eta i s$,torenvalk", enz. enz.; verderop zullen nog enige voorbeelden genoemd worden.

Doch ik wil geenszins de indruk wekken, dat alle woorden met inwendige $r$ tot bovengenoemde semantische groepen zouden behoren, of zouden hebben behoord; in elk geval zou een dergelijke voorstelling onbewijsbaar zijn. In een taal als het Toba-Bataks is het aantal dezer - $r$ - woorden groot, bij barsi ,niezen”, gordan „houten trommel”, arpas „spartelen (van een geslachte vogel)”, bortu „openbarsten (door vuur, hitte, bv. de huid)" e.a. kan men met meerdere of mindere waarschijnlijkheid veronderstellen, dat de $r$ tot het expressieve, algemener tot het ,primitieve" ${ }^{1}$ ) karakter van dit woord bijdraagt ${ }^{2}$ ), elders is het althans mij niet mogelijk er iets van te beweren: bij woorden die tuin (porlak), kuis (porman), inwikkelen (sorpi), moeilijk (garduk naast haduk), nacht (borniin) etc. betekenen. In deze gevallen staan we dan weer voor de moeilijkheid, die ik elders ${ }^{3}$ ) gesignaleerd heb: de woordbouw van de Indonesische talen in het algemeen vertoont eigenaardigheden die we, redenerend naar de uitkomsten van onderzoek op Indogermaans gebied, „primitief” kunnen noemen, en die ook op Indonesisch terrein met een zodanig karakter voorkomen. Overbodig te zeggen, dat het beeld van taal tot taal verschillende nuances kan tonen: in het Sasak bv. schijnen $\mathrm{mij}^{4}$ ), afgezien van leenwoorden, speciaal diernamen, en enkele woorden voor zich ,onregelmatig voordoen" ${ }^{5}$ ), gebruiksvoorwerpen, verder onomatopeën, Lautbilder tot de niet grote groep van $-r$ - woorden te behoren.

Keren we na deze opmerkingen over de $-r$-woorden terug tot het lintah-type.

In de vele gevallen, waarin een nasaal méér optreedt in aan vreemde talen ontleende woorden, hebben we zeker niet met een tot in Oer-Indonesische tijd teruggaand ,infix" te doen. Weer is het Van der Tuuk in zijn Tobasche Spraakkunst ${ }^{6}$ ) geweest, die daar voor deze

1) Over deze term zie Opmerkingen over ... comparatieve methode, Bijdr. 99 , pp. 418 vlgg.

2) Over de $r$ ook Remarks, p. 167.

3) Opmerkingen ... comp. methode, p. 431.

4) Naar een op grond van Goris' recente Woordenboek gekregen indruk.

5) Vgl. jërgit ,uitsteken (v. iets, dat met het andere behoorde gelijk te zijn)", cĕrpak ,gevorkt”, pěrson „(v. d. wangen) ingevallen”.

$\left.{ }^{6}\right)$ Van der Tuuk, Tobasche Spraakkunst, p. 44, sub a. 
taal op wees: „Uit de vergelijking blijkt het, dat de ligtere lettergreep nu eens gesloten, dan weder open is, en zelfs, dat men haar gesloten heeft in overgenomen woorden; bv. pitudar = bintudar (D.), sugapa $=$ sungapa ${ }^{1}$ ), umpama ..., tĕṅkuluk (D.) = tahuluk, rigarún (D.) = ringarun, laikawas (Bisaj.) uit lakawas, enz.". Interessant is bv. ook de wijze waarop het skt. woord sütra in de Archipeltalen vertegenwoordigd is: mal. sutĕra ,zijde(n draad)", jav. sutra, min. suta, maar bat. suttorá, surta, sintorá $\left.{ }^{2}\right)$. Ook Kern hield rekening met het verschijnsel: bis. mantili leidde hij van Maithili af $^{3}$ ); een verklarende opmerking maakte hij naar aanleiding van de tag. vorm sunhi $=$ sudhi' ,het zich vergewissen” : „de bijvorm sunhi is denkelijk ontstaan uit sundhi, waarin $n$ is ingelascht om zoo ten naaste bij den dubbelen medeklinker, die aan 't idioom vreemd is, weer te geven" $\left.{ }^{4}\right)$. In het Tontemboan verandert een inwendige $d$ in leenwoorden in $r$ of de $d$ wordt gepraenasaleerd of gepraehamzeerd ${ }^{5}$ ): kandera „rustbank" < mal. kadera, kĕdera, < port. cadeira ,zetel”, ga'nde „pand” < mal. (jav.) gadé. Voorbeelden uit andere talen : boel. jonke, gor. jonge < boeg. joge' „dansmeid”; soemb. bandil $<$ mal. bĕdil ; bim. rañki $<$ mal. rakit; bim. sampana $<$ mal. supana etc. $<$ skt. sopāna- „trap”; ndombulu $\left.{ }^{6}\right)<$ ned. dobbelen ; bim. mantaro $<$ ned. matroos; boeroe hambar < mal. (ar.) chabar, kempen ,geld" $<$ mal. kĕpin, sang. kumpirẹ < ned. papier, tbat. tarinka < mal. sětěrika $<$ ned. strïken, mak. mĕmporo < ned. mevrouw; atj. mĕnjĕlis naast mějĕlis < ar. mağlis ,vergadering”, mĕnjĕnun naast mĕjĕnun < ar. mağnūn ,bezeten”. „In Hova it chances that no words begin with $l+a+b$, but severals with $l+a+m+b$, hence the fr. la bride appears in Hova as lamburidi" ${ }^{7}$ ); hier legt de ontlenende taal z'n formele systeem op aan het vreemde woord; en is er duidelijke analogiewerking.

Voor het Maleis herinner ik aan ànkasa < skt. ākāśa-, antělas, ĕntělas naast atlas $<$ ar. ațlas, bandarsah, mandarsah $<$ ar. madrasah, bĕntala naast butala $<$ skt. bhütala-, Bĕntaram $<$ jav. Mataram, bĕranta < skt. bhärata-, cambok naast cabok < pers. čābuk, cĕntaka $<$ skt. cātaka-, cěntayu < skt. Jațāyu-, donsi < ned. doosje, gěmbala

1) Van der Tuuk's spelling gewijzigd.

2) Zie ook de opmerkingen van Kern, V.G. 10, p. 276.

3) Ibidem, 10, p. 284 ; cf. p. 286 s.v. $\operatorname{sinda}$, p. 282 s.v. gansuli.

4) Ibidem 10 , p. $276\left(a^{0} .1880\right)$.

5) Schwarz-Adriani, Hoofdstukken ..., p. 37.

6) Onvlee, Soemb. Vertellingen, p. XXI.

7) Brandstetter-Blagden, Essay IV, § 289.

D1. 101. 


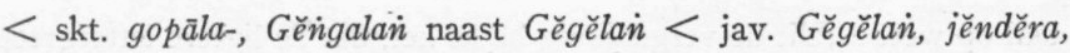
cĕndĕra naast ñĕdĕra, nidĕra < skt. nidrā-, jěntaka < skt. jātaka-, Kĕmbuli naast Kĕbuli, Kabuli < hind. Kabuli, lěmpiri $=$ nĕmpiri $<$ pers. nafïr $(i)$, lonisen, lonisin naast losen en dosen < eng. dozen, mĕṅkara < makara, mañkota etc. < skt. mukuta, manjapada naast majapada $<$ skt. ojav. madhyapada, Mĕndura $<$ Madura, Měngada $<$ Magadha, Mĕnkkasar < Makasar, měnta < skt. matta, měmpilai $<$ tam. mäppillai, nantiasa, nĕntiasa naast nĕtiasa $<$ skt. nityaśah,

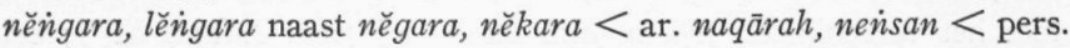
nīšān, rĕncana naast rěcana < skt. racana, samburna en semburna $<$ skt. suvarna-, Sĕmbadra $<$ Subhadrā, Santyaki naast jav. Sĕtyaki, těmbakau, těmbako etc. $<$ port. tabaco etc., umpama < skt. upamā, mol. mal. flingĕr $<$ ned. vlieger. Het valt op, dat de grote meerderheid der gevallen een derde lettergreep van achteren betreft. Ook in het Soendaas treffen we voorbeelden aan, o.a. bantarpas $<$ ned. waterpas, koncara over ojav. koccāra uit uccāra; in het Atjehs manjo $<$ majoor. Javaanse gevallen zijn onder meer anjudan $<$ ned. adjudant, anjun $\left.{ }^{1}\right)<$ ned. adjunct, ansli $<$ ar. așī, ancala $<$ skt. acala-, antyanta $<$ skt. atyanta-, bantala, běntala, buntala $<$ skt. bhütala-, dirvainkara $<$ skt. divākara-, ka-jantaka $<$ skt. jātaka-, kominḍi, naast komiḍi < europ. komedie, kĕmintir naast kĕmitir $<$ gecommitteerde, manuinsa naast manusa etc., mañsa < skt. māsa-, mintuna $<$ skt. mithuna-, minañsraya van skt. āśraya, mintaraga $<$ skt. vītarāga-, munisig < ned. muziek, eng. music, montip $<$ ned. locomotief, montor < ned. motor, naìkoda < perz. nāhnudā, néndra skt. nidrā-, nimpuna $<$ skt. nipuna-, ninkah naast nikah, o.jav. parintosa naast $(<$ skt.) paritoșa, pĕrgandrin $<$ ned. vergadering, pěrminsi naast permisi $<$ ned. permissie, rumañsa bij rasa, umpama $<$ skt. upamā-, untara $<$ skt. uttara-, sĕngata $=$ sugata $<$ skt. svāgata-, se(n)tèlèn $<$ stelling en tentoonstelling, sěntolop $<$ sĕtolop $<$ ned. stolp, Sinta naast Sita, sumbaga < skt. subhaga-, trañgana $<$ skt. tārāgana-, yoḍemmporěm < ned. jodoform, e.a. ${ }^{2}$ ). Reeds A. W. T. Juynboll ${ }^{3}$ ) gaf een aantal voorbeelden van uit het Arabisch en Perzisch ontleende woorden, die deze verandering hebben ondergaan: jav. pampus < perz. pāpoš, an்sal naast asal < ar. așal, ea., ,eene opene lettergreep wordt dikwijls door eene neusklank gesloten... maar vooral... met... $\dot{n}$ ". Er zijn er meer dan in de woorden-

1) D.i. dus andjoen.

2) Ook surigata $<$ skt. sugata-, astunikara.

3) In: Lijst van Java.... wdn uit het Arab. etc. (zic boven), p. 30. 
boeken vermeld staan : àigranasika $<$ skt. agranāsika-, de eigennaam Bagaděnta $<$ skt. en ojav. Bhagadatta, mandira $<$ skt. madirā, manta $<$ skt. matta- $^{1}$ ), winkara $<$ skt. vikāra- ${ }^{2}$ ), en andere woorden. Ook hier treedt het verschijnsel vaak op in de $3 \mathrm{e}$ syllabe van achteren, men krijgt ook de indruk, dat in woorden waarin reeds een nasaal voorkomt de ,epenthesis” enigszins frequenter is. Merkwaardig zijn de gevallen als sěntolop. Nasalering in de voorslag bij leenwoorden vindt men bv. in soend. ĕngas $<$ ned. gas, ĕ $\dot{n} k o l<$ ned. kool. Esser merkt ${ }^{3}$ ) op, dat men in mori ansitee < ned. assistent ,de neusklank heeft behouden door hem te doen verspringen"; dit is m.i. slechts een mogelijkheid.

In Europese talen is deze $n$ in leenwoorden welbekend. Soms is hij steeds anwezig, soms beperkt tot "dialektische”, soms tot min of meer constante individuele uitspraak. In Franse woorden in het Rijnlandse Duits hoort men hem bv. in desentieren $<$ desertieren, profentieren, vesentieren, runjenieren etc. ${ }^{4}$ ), ook konkarde, cintadelle, dial. kunjenieren naast kujonieren, in het Nederlands eveneens ${ }^{5}$ ): visenteren $<$ visiter, montet $<$ motet, singlatoen $<$ ciglaton, brancoen $<$ bracon, komfoor $<$ chauffoir, ook in ampart $<\grave{a}$ part, spansieren $<$ du. spazieren ${ }^{6}$ ), fambliek $<$ fabriek, vermalendien, pampier $<$ papier, kamperfoeli $<$ lat. *caprifolium, fansoen, fantsoen $<$ fr. façon, rampier naast rapier, winket; pangaaien, dat naast pagaaien voorkwam, is misschien ook een voorbeeld ${ }^{7}$ ); onze voorouders maakten van $M u \dot{g} u l$ : Mongool, van perz. jāmadār ,politiechef” niet alleen simedaar, maar ook jamindar ${ }^{8}$ ), van arab. ațlas „,satijn” wel antělas, dat ze echter ook zó gehoord kunnen hebben ${ }^{9}$ ). In het Frans is gingembre $<$ lat. zingiberi, gala $(n)$ tine $<$ m.e. lat. galatina, ancolie $<$ m.e. lat. aquilegia $\left.{ }^{10}\right)$, concombre $<$ cocombre, coucombre $<$

1) Çrī Tañjung 5,50 .

2) Çrī Tañjung 1,8 .

3) Esser, Klank- en vormleer van het Morisch, p. 15, n. 1.

4) Meer voorbeelden bij W. Horn, Zs. f. franz. Spr. u. Litt. 22 I (zie boven), t.a.p.

5) Voorbeelden ook bij Logeman, in Taal- en Letteren 14 (1904), p. 258 vlg.

6) Vgl. Salverda de Grave, Les mots dialectaux du Français en MoyenNeerlandais, Romania 30 (1901), p. 110.

7) Prick van Wely, Neerlands Taal in 't verre Oosten, p. 169. Mogelijk is hier de vorm met nasaal de meer oorspronkelijke.

8) Zie Stapel, Corpus diplomaticum V, Bijdr. Kon. Inst. 96, pp. 140; 632.

9) Ik verwijs ook naar de opmerkingen van Veth, in De Gids 1867, p. 443, over port. monção, fr. mousson (ook, XVII' eeuw,) monson, ned. moeson < arab. mausim.

10) Ned. akelei; men denkt aan invloed van mélancolie, waarvan deze plant in Frankrijk het symbool was. 
prov. cocombre < lat. cucumerrem, acc. van cucumis, pompon < lat. pepo; naast Portugal stond een oud adjectief Portingalois ${ }^{1}$ ). Ital. paragone werd sp. (en fr.) parangon; fr. gripper ,met de klauwen grijpen" < germ. grîpa heeft als nevenvorm grimper. In het Engels heeft men muchinder $<$ lat. mucatorem, solentary $=$ solitary $^{2}$ ), nightingale $\left.{ }^{3}\right)$, schots pot(t)ingar $<$ fr. apotecaire, clavenger $<$ claviger, foranger $<$ forager, celandine $<$ ofr. celidoine (gr. $\chi \varepsilon \lambda \iota \delta o ́ v ı v)$, palantine $\left.{ }^{4}\right)$, brigander $=$ brigadier; in dialekten milintary, skelinton. Meer dan eens is het moeilijk te beslissen, in welke taal de $n$,,voor het eerst” optreedt; eng. messenger gaat terug op ofr. messagier, maar ook het M.Ndl. heeft messengier ${ }^{5}$ ). „Der Nasaleinschub im Slawischen", schreef Schuchardt ${ }^{6}$ ), ,geht auf drei Hauptquellen zurück... und jedenfalls tritt er vor allem in Lehnwörtern auf”. Nederlanders in Indië hebben nogal eens de gewoonte een $n$ extra te zeggen: gelantine i.p.v. gelatine ${ }^{\tau}$ ). Interessant is de ontleningsgeschiedenis van het woord hebr. šabbāt $>$ gr. $\sigma a ́ \beta \beta \alpha \tau o v$ $>$ vulg. lat. sambatum $>$ ohd. sambaz-tac $>$ du. samstag; in het ofr. sambedi, sambadi < vlat. sambatidies; roem. simbătă etc., hong. szombat, oslav. sabota etc. ${ }^{8}$ ). Semietische woorden met $-b b$ - treden in

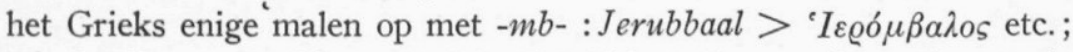

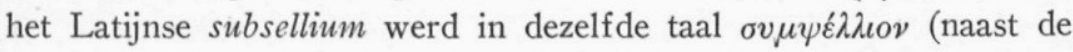

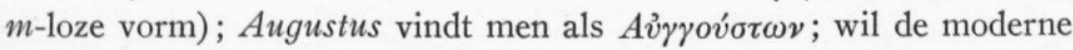
Griek de media van bv. een Italiaans woord weergeven, dan schrijft hij $\mu \pi, \gamma \varkappa, v \tau$, d.i. $m b, \dot{n} g . n d$; ook in zijn uitspraak hoort men, zoals gezegd, $\min$ of meer duidelijk een voorgeslagen nasaal ${ }^{9}$ ). „Die Klein-

1) Zie O. Ritter, in Archiv f. d. Studium der neueren Sprachen und Literaturen 113 (1904), pp. 31 ff.

2) Zie O. Jespersen, A modern English Grammar (1909) I, p. 35.

3) Jespersen, The nasal in Nightingale, Engl. Studien 31 (1902), p. 239, naar aanleiding waarvan zich een discussie in de tijdschriften ontspon.

4) Zie Ritter, t.a.p.

5) Een leerzaam geval: in 't Middel-Nederlands bestonden: messelgier, metselgier, meysalgier, messalgier, messailgier, messegier, messengier, metsagier, messelier, mosselgier, massagier, massilieer, missagier, misselgier, naast messagier.

6) Schuchardt, Zum Nasaleinschub, Zs.f. Roman. Phil. 35 (1911), p. 110.

$\left.{ }^{7}\right)$ Zie ook J. van Ginneken, Handboek der Nederl. Taal, I ${ }^{2}$, p. 321.

8) G. Meyer, Indog. Forsch. 4 (1894), p. 326 vlg.

9) A. Thumb, Die Griechische Sprache im Zeitalter des Hellenismus (1901), p. 135. „Neugr. nas. + med. statt alter med. $\beta, \gamma, \delta$ (oder auch alter Tenuis) ist ... ziemlich selten ... und (abgesehen von ganz wenigen Wörtern) auch

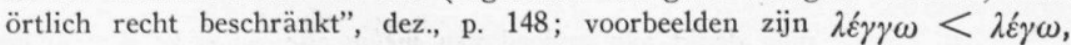
$\varepsilon \gamma \varkappa \lambda \eta \sigma \iota \alpha<\varepsilon x x \lambda \eta \sigma i \alpha$. 
asiaten welche keine reine Media aussprechen konnten, sprachen entweder Tenuis oder Nasal und Media, welch letzteres auch die meisten heutigen Griechen thun (àvrio = adio usw.)" ${ }^{1}$ ).

De conclusie schijnt mij voor de Indonesische talen, voorzover hier ter sprake gekomen, reeds nu gewettigd, dat de gevallen met ,inwendige nasaal" en die met ,inwendige $r$ ", waarin deze klanken niet als infix te beschouwen zijn, geheel vergelijkbare zijn.

Maar welke factoren zijn nu werkzaam geweest en nog werkzaam bij het ontstaan van het woordtype met inwendige nasalering op Indonesisch gebied, en zien we ook hier een parallelisme met $r$ woorden? Dempwolff merkte al op, dat sommige woorden zich aan zijn hypothese onttrekken. Een belangrijke factor lijkt mij te zijn het verschijnsel, wel beter: de groep verschijnselen, die men wel de naam geeft van ,,spontane nasalering" ${ }^{2}$ ), of ook wel onder epenthesis (van $n, r$ etc.) samenvat. In allerlei talen is reeds lang opgemerkt, dat hetzij in de algemene taal, hetzij in dialekt, hetzij in individuele uitspraak in bepaalde woorden een niet-etymologische klank ontstaan, a.h.w. „er bij gekomen”, ,ingeschoven” is. We kunnen de naam epenthesis, waaronder men niet steeds hetzelfde verstaan heeft

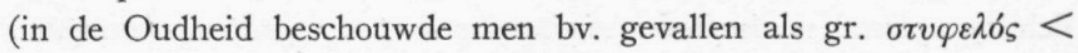
$\sigma \tau v \varphi \lambda o_{s}$ en $\sigma \pi \alpha i \varrho \omega$ bij een wortel $\sigma \pi \alpha \varrho-$ als voorbeelden van epenthesis), mits we hem nauwkeurig definiëren en ons losmaken van zijn voorgeschiedenis, en van de reminiscenties an het schriftbeeld die hij oproept, m.i. wel blijven gebruiken.

Er valt, dunkt mij, niet aan te twijfelen, of zowel de nasaal als de liquida in een woord hebben ook in IN. talen meer dan eens hun aanzien te danken aan ,epenthesis" en zijn ook dan geen infix of verstard infix.

Ofschoon het mij wil voorkomen, dat een samenvattend onderzoek naar het voorkomen en de oorsprong van dit verschijnsel nog tot de desiderata der taalwetenschap behoort, is er reeds een vrij omvangrijke, meestal tot kortere opmerkingen en incidentele besprekingen beperkte, literatuur over het onderwerp, waaruit blijkt, dat de zg. ,spontane nasalering" in menige taal voorkomt ${ }^{3}$ ). Onder „epéntesis” zegt Menendez Pidal ${ }^{4}$ ) o.a.: „....sin razón aparente se

1) A. Thumb, Die griechischen Lehnwörter im Armenischen, Byzant. Zs. 9 (1900), p. 411.

2) Veiligheidshalve desnoods tussen „..." of van zg. voorafgegaan.

3) Ik verwijs ook naar Trombetti, Elementi di Glottologia, p. 511 vlg.

4) R. Menendez Pidal, Manual de Gramática histórica española ${ }^{4}$, Madrid 1918, § 68, p. 145. 
desliza un sonido entre los latinos; las letras añadidas son nasales y líquidas: $m, n$ : subbullira $>$ zabullir y zambullir, sosacar y sonsacar etc.; ya en latín vulgar se díjo mancula pro macula ..., ant. y vulgar muncho por mucho; *alaudula $>$ *alodra, alondra ...", voorts manzana $<$ matianum etc., soms onder invloed van een volgende $n$ : plantano $<$ platanus, dan weer niet: fincar naast ital. ficcare ${ }^{\mathbf{1}}$ ). In het Roemeens : pecíngine $<$ petīginem e.a. ${ }^{2}$ ). Zoals door Schulze ${ }^{3}$ ) is aangetoond, is uit varianten in Griekse handschriften, uit laatGriekse auteurs en moderne dialekten interessant materiaal voor onze kwestie te putten: $x \varepsilon ́ v \delta \varrho o \varsigma=x \varepsilon ́ \delta \varrho \circ$, $\lambda \dot{\alpha} \mu \beta \delta \alpha=\lambda \dot{\alpha} \beta \delta \alpha, \dot{\varepsilon} \gamma x \lambda \eta \sigma i \alpha=\dot{\varepsilon} x x \lambda \eta \sigma i \alpha$, de Gallische stam der

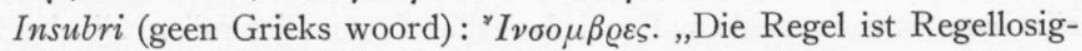
keit", maar toch zijn al deze oudere en jongere Griekse genasaleerde nevenvormen uitingen van eenzelfde, zij het dialektisch of soms zelfs individueel werkende tendenz. In het Latijn zijn er eveneens gevallen ${ }^{4}$ ), bv. labrusca : lambrusca; lacusta: langusta, sabucus : sambucus. Lat. strabus werd it. strambo, vapor $>$ vampo, Ebrodunum $>$ fr. Embrun, Sabis $>$ fr. Sambre. Ook op Duits gebied is er menig voorbeeld van een nasaal, die ,,vorübergehend oder nur mundartlich" ${ }^{5}$ ) optreedt: súmfton: siufton, grampen: grapen, klumpen: klupen, gnimpen: gnippen, schwampeln: schwappeln, etc. In het Frans is grincer ,forme nasalisée du moyen fr. grisser" ${ }^{6}$ ), vgl. ook dondon naast dodeliner, bombance naast bobance ${ }^{7}$ ), voorts bibelot: bimbelot $^{8}$ ), ook worden vermeld englise naast église, englentier, cimentire e.a. $\left.{ }^{9}\right)$, dan bribe: brimbe ,chose de peu de valeur”, breborion, briborion, brimborion „menu objet”, ficelle $>$ fincelle, ginguer ,forme nasalisée de giguer", jumbarba $<$ joubarbe $<$ Iovis barba, clinquer : cliquer, pimprenelle $=$ piprenelle. Nederlandse voorbeelden zijn: einselijc naast eizelijc ${ }^{10}$ ), niemendal $<$ niet-med-al,

1) Zie ook Gröber's Grundr. d. Rom. Phil. I, p. 707, waar andere voorbeelden.

2) Tiktin, in Gröber, o.c., I. p. 430.

3) W. Schulze, Kuhn's Zs. 33, p. 366 vlgg.

4) Zie A. Graur, Les consonnes géminées en Latin, Diss. Parijs 1929, p. 94 vlg.

5) Weinhold, Alemanische Grammatik, § 167, § 201.

6) A. Dauzat, Dict. étymol. (1938), p. 375.

7) W. v. Wartburg, Etym. Wtb. I, 419.

8) Waarover W. Foerster, Zs. f. Rom. Phil. 22 (1898), p. 263.

9) Ritter, o.c., p. 34 .

10) Jan te Winkel, in Paul's Grundriß der Germanischen Philologie I, p. 829 (1901), later vooral in onbeklemtoonde syllaben. 
borendevol < (ten) boorde vol $\left.^{1}\right)$, dialektisch bv. ènkeuantien $=$ eekhoorn (Kampen) ${ }^{2}$ ), stànketsal $=$ staketsel $^{3}$ ) (leenwoord). In Engelse dialekten is het verschijnsel bekend: in S. Norfolk luiden midge en ridge: mindz en rindz ${ }^{4}$ ). Men vergelijke ook overeenkomsten als mnl. scrompelen, ned. schrompelen, du. schrumpfen enerzijds en o.noors skorpinn „verschrompeld”, skorpna „schrompelen" anderzijds.

In de Indo-Arische talen treffen we van ons verschijnsel talloze voorbeelden aan, en er is dan ook reeds meer dan eens de aandacht op gevestigd ${ }^{5}$ ). Grierson betoogde reeds lang geleden ${ }^{6}$ ), dat de door hem spontaan genoemde nasalering in deze talen veel vaker voorkomt dan we uit de literaire dialekten alleen zouden opmaken. Speciaal in de ,rural dialects” is ze frequent. „In the rural dialects many more such pairs can be heard of which no trace will be found in the dictionaries. Such cases are rather instances of the personal equations of the respective speakers than of local dialect. In the same village one man may say $s \tilde{\bar{a}} c$ and another may say sañc, or the same man may say one or other as the rhythm or the style of the sentence may demand" ${ }^{7}$ ). Men vindt dus tweeërlei spontane nasalering: zg. anunāsika (,nasalering") en de klassenasaal behorende bij de volgende occlusief (homorgane nasaal): zo heeft men tegenover skt. karkara-, pr. kakkara-, beng. kãarkar, h. kaikar. Het verschijnsel is oud: naast skt. vakra- ,gebogen, scheef, krom" vindt men pr. niet vakka-, dat we zouden verwachten (als cakra- ,wiel” : cakka-), doch vamka, en zo naast skt. puccha- „staart” pumcha- en niet puccha-. Grierson wees er op, dat deze zg. onregelmatige woorden deśí-termen zijn, d.i. afkomstig uit de ,provinciale volkstalen”; en dat hier overgang van dubbele consonant in nasaal of nasaalvocaal + consonant veelvuldig voorkomt. In sommige dialekten, bv. in Kaschmir, is het

1) Zie Logeman, Taal en Letteren 14 (1904), p. 258 vlg.

2) J. Gunnink, Het dialect van Kampen e.o., Diss. Amsterdam 1908, p. 50, waar meer.

3) Grootaers en Grauls, o.c., p. 111. Voorts kabuis: kombuis e.a.

4) B. Grüning, Schwund und Zusatz von Konsonanten..., Diss. Straßburg 1904, p. 64.

5) Zie bv. J. Bloch, La formation de la langue Marathe, § 67 en 70; dez., „La Nasalité en Indo-Aryen", in Cinquantenaire de l'École Pratique des Hautes Études; R. L. Turner, Gujerati Phonology, JRAS. 1921, p. 344; Grierson, Spontaneous Nasalization in the Indo-Aryan Languages, JRAS. 1922, p. 381 vlgg.

6) Grierson, ZDMG. 1896, p. 21 vlg.

7) Grierson, JRAS. 1922, p. 384. 
verschijnsel zeer frequent ${ }^{1}$ ). Ik merk nog op, dat men in het Sanskrit bv. naast gabhīra- „diep" gambhīra-, in het Prākrit naast nāga„,slangedaemon" wel nāinga-, naast nagara- ,stad” wel nangara-, in Prākrit en Pāli naast sigāla- ,,jakhals" singāla- vindt $\left.{ }^{2}\right)$. De welbekende nasaal in het Sanskrit woord voor "twintig", vimśati-, tegenover lat. viginti etc. heeft tot velerlei opmerkingen aanleiding gegeven ${ }^{3}$ ); ook in turanga- ,paard” naast turaga- (tura- ,,snel etc." + ga- ,gaande”), vihainga- naast vihaga- ,vogel”, bhujainga- naast bhujaga- ,slang" moet men met deze $n$ rekening houden.

Ook in de Indogermanistiek kent men gevallen van etymologische aequivalenten met en zonder $n$. Hier is het verschijnsel door de coëxistentie van de $\mathrm{zg}$. nasaalpraesentia en van suffixen die een $n$ bevatten ingewikkelder. Ik kan er in dit verband niet op ingaan, herinner er slechts aan, dat reeds Hirt terecht opmerkte ${ }^{4}$ ): „In ausgedehntem $\mathrm{Maße}$ (waarbij op te merken valt, dat meer dan een van de voorbeelden die hij doet volgen op een twijfelachtige etymologie berust) stehen im Indogermanischen nasalierte Formen neben unnasalierten. Man spricht von einem Nasalinfix, womit aber nichts gesagt ist”. Er zijn enkele gevallen, zoals lat. fundus „,bodem” tegenover o.ind. budhna- ,grond, bodem", die zich op meer of minder bevredigende wijze door metathesis (,umstellung”) laten verklaren ${ }^{5}$ ); lat. unda ,water, golf” is reeds minder zeker: enerzijds kan men het met gr. 'A $A \lambda \sigma-v \delta \delta v \eta$, oind. gen. $u d-n$-as vergelijken; anderzijds is er op gewezen ${ }^{6}$ ), dat hetzelfde "nasaalinfix" voorkomt in de andere taalgroep ,où les infixes nasaux ont pris un grand développement, le letto-lituanien": lit. vandũ, tegenover got. wato, ohd. wazzer, hitt.

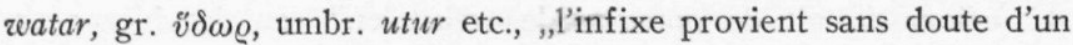
présent non conservé dans ces deux langues, mais que connait le sanscrit: unatti, 3 pl. undanti' ${ }^{7}$ ), maar anderen hebben een omge-

1) Zie voorts bv. ook Morgenstierne, Notes on Phalūṛa (Norsk. Vidensk.Akad. II. 1940. 5), Oslo 1941, § 8.

2) Zie ook Lüders, in Sitzungsberichte der Preuss. Akad. der Wiss., 1916, p. 736: „Nasaleinschub”. Voorts piñcholā: piccholā „luit” (Āp. Çr. S. 21, 17, 16), pāmiśupata- (Jahn, Saura-P., p. XIX), śi(m)śunāra-.

3) Debrunner-Wackernagel, Altindische Grammatik, III, p. 366.

4) H. Hirt, Indogermanische Grammatik I (1927), § 168, 2.

5) Met Thurneysen, Kuhn's Zeitschrift 26, p. 301; vgl. ook H. Petersson, Studien über IdG. Heteroklisie, Lund 1921, p. 17; Walde-Hofmann, Lat. etym. $\mathrm{Wtb}^{3}$ (1938), p. 564 vlg.

$\left.{ }^{6}\right)$ Ernout-Meillet, Dict. étym. de la langue latine, p. 1082; vgl. Meillet, MSL. 21 , p. 113.

7) Vgl. ook Brugmann, Grundriss d. Vergl. Gramm. d. IdG. Spr. ${ }^{2}$, II, 1, p. 146 . 
keerde redenering gevolgd. Er zijn echter ook gevallen waar nòch van nasaalpraesentia, noch van suffixen met nasaal sprake is: lat. anguis ,slang” : gr. ö $\varphi$ ı, oind. ahi-, waar echter niet één oervorm te construeren is; gr. $\lambda v \gamma^{\prime} \xi^{1}$ ) „de los" : ohd. luhs, lit. lúszis etc.; gr.

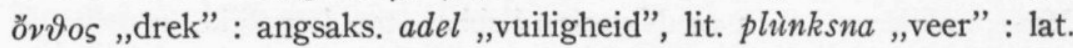

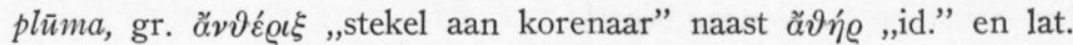
ador ,spelt" etc.. De meeste voorbeelden behoren tot de groep van ,affectieve” en ,populaire” woorden, wat, bij globale overeenstemming van het probleem met dat op Indonesisch gebied, daartegenover een beperking betekent.

Ik herinner er, in aansluiting bij het reeds boven ter sprake gekomene, aan, dat immers in vele talen onomatopoëtische en dergelijke formaties, Reduplikationsbildungen en wat zich daarbij aansluit, een duidelijke voorkeur voor verbindingen van nasaal of liquida + con-

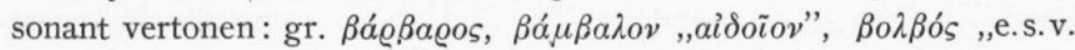

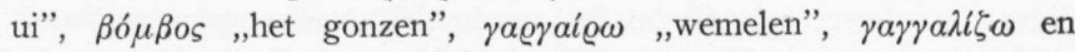

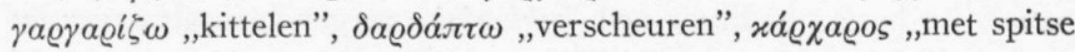
tanden”, ломфó $v v \xi$,,waterblaas” etc. ${ }^{2}$ ). „Bei Schallwörtern kann auch

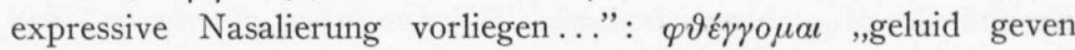
enz.”, $x \lambda \alpha \gamma \gamma \eta \dot{~, k l a n k ”, ~ \tau v ́ \mu л а v o v ~, p a u k ” . ~ V o o r t s ~ i n ~ h e t ~ G r i e k s ~ v a n ~}$ Zuid-Italië $\beta о \mu \beta v \lambda o s$,enghalsiges Tongefäß”, „das Wort beruht zweifellos auf Schallnachahmung und wird offenbar den glucksenden Ton des aus dem langen Hals laufenden Wassers wiedergeben" ${ }^{4}$ );

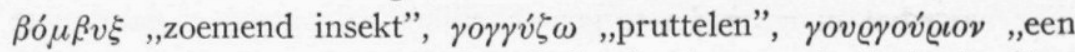
groot zwijn”. Dan bv. ook ital. balbuzie ,'t stamelen”, barbugliare „stotteren”, borbogliamento „rommelen (van de buik)”, borbottare „,morren, ('n taal) radbraken”, brontolare „brommen”, dindin ,klinkklank", dondola ,schommel”, farfalla ,,vlinder”, farfanicchio ,,kletser, zwetser”, gargarizzare „gorgelen”, gorgozzule ,gorgel”; fr. bimbelot naast bibelot, bourbouille, dondon naast dodeliner, gargoter, quincaille $<$ clincaille; lit. balbatúoti ,snappen, babbelen”, bambù ,brommen”, brenzgu „rinkelen”. Ook Latijnse voorbeelden zijn er: grundire „knorren (v. varkens; du. grunzen)”, fringilla „vink”, frendĕre „,knarsen (met de tanden, etc.)”; duidelijke klanknabootsing vinden we bv. in vogelnamen als turtur, turbelix, quarquara, vgl. parsito $=$

1) Brugmann, t.a.p. anders.

2) $\mathrm{Zie}$ voorts de lijst bij Ed. Schwyzer, Griech. Gramm. I (1939), p. 423, ook p. 647.

3) Dezelfde, p. 692.

4) G. Rohlfs, Etym. Wtb. der unteritalischen Gräzität (1930), s.v. 
passito „(van de spreeuw) schreeuw”; men lette ook op gurgulio „keel”, curculio „korenworm” ${ }^{1}$ ), murmillo ,e.s.v. gladiator”, bambilium „e.s.v. muziekinstrument”, girgillus „draaiende hefboom bij een bron”, querquerus, adj. bij febris ,koorts” : „koude (koorts)” ${ }^{2}$ ). Maar, gelijk we boven reeds gezien hebben, tot dergelijke woorden is het verschijnsel nagenoeg beperkt.

Men mag niet uit het oog verliezen, dat ondanks een zekere althans schijnbare spontaneiteit in de ontwikkeling van een inwendige nasaal er toch andere invloeden zich daarbij kunnen doen gelden. Ik hoorde eens een jongen, die een verhaal deed van een op straat overreden en stervend katje, het woord kramperen gebruiken; hij bedoelde het woord creperen te bezigen, maar mede door de krampachtige stuiptrekkingen van het diertje associeerde en vermengde zich in zijn geest en taal dit woord met kramp. Hier kwam de inwendige nasalering zonder twijfel tot stand door ,blending”, een term, die ik, naast „kruising”, liever gebruik dan het aan kritiek onderworpen „,contaminatie". Zo heeft het Frans ned. kakkerlak overgenomen als cancrelat ,avec attraction de cancre”; de naam van het zwaard van den held Renaud de Montauban, froberge, floberge werd flamberge "par attraction de flamme". Zo heeft men gr. xó $\gamma \xi \alpha$ naast $x o ́ \xi \alpha$,knieholte" als blendingsproduct van dit woord en $x o ́ \gamma \chi \eta$,knieschijf" verklaard $^{3}$ ), $x a ́ \mu \psi \alpha$ „doos, étui, enz." naast $x a ́ \psi \alpha$ uit invloed van xá $\mu \pi \tau \varepsilon \iota v$,buigen”, $x a ́ \mu \pi \tau \varrho \alpha=x a ́(\mu) \psi \alpha$. Het is duidelijk, dat dergelijke woordvermenging des te gemakkelijker zal optreden, naar mate beide woorden grotere onderlinge gelijkenis in klank en verwantschap in betekenis vertonen. Vaak is de knoop niet of nauwelijks te ontwarren: fr. pincer, ,du lat. vulg. ${ }^{*}$ pinctiare, formation onom., ou croisement entre *punctiare (v. point) et *pīccare, „piquer" (sens de l'it. pinzare, esp. pinchar)" "), waarbij aan te tekenen valt, dat men, vooral vroeger, meermalen te ver gegaan is in het aannemen van Vulgair-Latijnse ,oervormen” om dergelijke Romaanse woorden te verklaren. Leerzaam is ook de geschiedenis van het woord lantaarn: als leenwoord uit het gr. ( $\left.\lambda \alpha \mu \pi \tau \eta^{\prime} \varrho\right)$ had het Latijn, naar men wel aanneemt onder kruising met lucerna ,lamp" lanterna ${ }^{5}$ ), hoewel er

1) „Sans doute mot populaire à redoublement intensif”, Ernout-Meillet, Dict. étym. de la langue latine, 1932, p. 236.

2) "Mot expressif”, ibid. p. 800.

3) Schuchardt, Zum Nasaleinschub, Zs. f. Rom. Phil. 35, p. 84.

4) Dauzat, Dict. étym. de la langue française, p. 560.

5) Zie bv. Ernout-Meillet, Dictionnaire étymologique de la langue latine, s.v. (p. 496). 
meer voor Etruskische herkomst van -(er)na- te zeggen valt $\left.{ }^{1}\right)$, en een nevenvorm laterna, die goed uit dissimilatorisch verdwijnen van de eerste $n$ te verklaren is; de vorm is echter volksetymologisch met latere „,verborgen zijn" verbonden : bij een lantaarn, die voor het gebruik buitenshuis bestemd was, diende men de vlam tegen de wind etc. te beschutten; dit geschiedde met doorzichtige stof: geolied doek, huid, hoorn, later ook glas ${ }^{2}$ ), maar zo ging de vlam schuil. Van de $n$-loze vorm, die dus jonger is, stamt du. laterne, van die met $n \mathrm{fr}$. lanterne etc.

Er zijn voorts voldoende gegevens om een zekere samenhang tussen het optreden van spontane nasaal of liquida en nog andere primitieve tendenzen dan de reeds genoemde aan te nemen. Een zekere tendenz naar expressiviteit, naar krachtbijzetting in bepaalde, lagere taalkringen levend, en ook elders in affectische uitingen vertegenwoordigd, tendenz waaraan bv. ook het optreden van het welbekende verschijnsel van consonantengeminatie - lat. Varro bij vārus, gr. $\gamma v ́ v v \iota s$,wekeling” bij $\gamma v v \dot{\eta}$, etc. — is toe te schrijven, valt ook hier aan te nemen, eveneens de mogelijkheid tot een zekere klanksymbolische werking. Afgebakende grenzen met klanknabootsende en expressieve woorden heeft deze groep, overbodig te zeggen, niet. Men denke in dit verband bv. aan eng. bump, thump, dump, ned. stamp naast stap, homp, klampen, bedompt, stomp, plomp etc., aan paren als du. knistern: knirschen. Nederlandse woorden als denderen, donderen, gorgelen, karkiet, tjirpen (tjilpen), als drentelen, spartelen, glimpen, glinsteren, sprankelen, strompelen, tintelen, geluids- en bewegingswoorden dus, hebben vaak nasaal of liquida voor consonant ${ }^{3}$ ). Hetzelfde is op te merken bij de Duitse formaties op -ern en -eln, voornamelijk in omgangs- of zelfs ,volkstaal" in gebruik, en vaak affectief-expressief: lungern, rankern, quergeln, quengeln, murmeln, humpeln. Evenzo bij Engelse uitdrukkingen op -le, die herhaalde geluiden enz. aanduiden: burble, grumble, jingle, tingle, rumble, voorts chortle $\left(<\right.$ chuckle + snort $\left.\left.^{4}\right)\right)$; er vinden echter nog

1) Dwz. dan is het woord "door Etruskische bemiddeling" in het Latijn gekomen.

2) Zie bv. R. Cagnat et V. Chapot, Manuel d'archéologie II, p. 475 (met afbeeldingen).

3) Over de cons. + voc. $+n$ etc. + cons.-woorden wordt bv. ook gesproken door H. Hilmer, Schallnachahmung, Wortschöpfung und Bedeutungswandel, Halle 1914, wiens combinaties echter, o.a. op semantische gronden, meer dan eens aanvechtbaar of onzeker zijn.

4) Volgens E. Partridge, A dict. of English slang ... (1937), p. 151. 
meer semantische groepen op deze wijze uitdrukking ${ }^{1}$ ): onduidelijk of snappend spreken: mumble e.a., onrustige, waggelende, strompelende bewegingen: stumble, grabbelen en derg.: scramble; onbeholpen, verwarde, tastende bewegingen: fumble, jumble, kibbelen en derg. jangle, worangle; vgl. voorts wrinkle, crumple, rumple, dandle enz. Wat de oorsprong ook zij: affectief karakter slijt uit en kan geheel verloren gaan. Ook zal niet ieder voorbeeld dat men zou willen aanhalen zich kunnen onttrekken aan andere uitleg, nl. als reactieverschijnsel tegen ,tot uitvallen neigende” verzwakte syllaben, beinvloeding van rhythmisch verwante woorden en dergelijke ${ }^{2}$ ). Hier zou men in die IN. talen en dialekten waar de neiging bestaat een woord van het type těpat als tpat uit te spreken aan kunnen denken; een onderzoek ter plaatse zou wellicht iets kunnen opleveren. Beneden volgen hierover nog enige opmerkingen.

Ik noemde het verschijnsel der consonantengeminatie. Bij de Latijnse en andere woorden met gegemineerde consonant waarvan het expressieve karakter is aangetoond ${ }^{3}$ ), bestaan voorts nevenvormen met nas. + cons.: accipenser: ancipenser ,steur”, blatta: blanta „mot, boekworm”, gimbus : gibbus ,bochel”. Sommigen gaan hier in details en in hypothesen verder dan mij verantwoord schijnt, zo bv. Sauvageot ${ }^{4}$ ), die evenwel op interessante Germaanse verschijnselen wijst, o.a. eng. to shrink : du. schrecken; ohd. stinkan : oijsl. stóekr; ned. slank : eng. slack, mhd. zacke: zanke. Er zijn inderdaad verscheiden dergelijke paren in de Germaanse talen als eng. pink ,to stab”, naast pick, cf. prick.

Meer dan eens valt ook de overgang op van de hierboven vermelde „dubbele consonant" (waaronder men te verstaan heeft de combinatie van een implosieve en een explosieve, niet een verlengde consonant) in $n+$ cons. of $r+$ cons. „Bekannt ist die Auflösung eines verdoppelten Konsonanten im Hebräischen und Aramäischen in $n$ oder $r+$ Kons." $^{5}$ ). Van paren als arab. sumbula: subbula ,aar", hebr.

1) Vgl. ook Fröhlich, Zusammenhang zwischen Lautform und Bedeutung bei englischen Wörtern, in Die neueren Sprachen, 33 (1925), p. 133 vlg.

2) Over dergelijke zaken bv. O. Ritter, Archiv f.d. Studium d. neueren Sprachen und Literaturen 113 (1904), p. 34; Luick, ibid. 114, p. 77. Volgens Salverda de Grave (Handelingen, zie boven, p. 96 ) is de $-l l$ - in vallei en sallade in het Nederlands reactie tegen de uitspraak vlei (en sla).

3) A. Graur, Les consonnes geminées en Latin, Diss. Paris 1929, zie p. 97.

4) A. Sauvageot, Sur quelques faits de nasalisation expressive en Germanique, Mélanges-Vendryès 1925 , p. 317 . Op p. 322 , n. 1 Hongaarse voorbeelden.

5) Kampffmeyer, Alte Namen im heutigen Palästina und Syrien I, Leipzig 1892 , p. 83 , waar bijzonderheden. Zie ook Fränkel, Die aramäischen Fremd- 
šarbīt : šabbīt , ,skepter” zijn vele voorbeelden te noemen ${ }^{1}$ ). In het levende Hebreeuws moet de „Auflösung einer Verdoppelung durch einen Nasal" meermalen voorgekomen zijn ${ }^{2}$ ). Ook elders : in Ho-

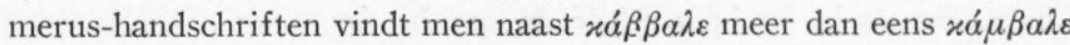
en dergelijke lezingen, en Semietische woorden met - $b b$-, in het Grieks bijna onbekend, zijn in laatstgenoemde taal enige malen met $-m b-$ overgegaan: Jerubbaal $>{ }^{\prime} I \varepsilon \varrho o ́\left(\mu \beta a \lambda o \varsigma^{3}\right)$. Men heeft voorts gewezen op gevallen als fr. rendre < lat. redděre, waar echter kruising met prenděre $>$ prendre zal hebben plaats gehad; voorts kan men noemen calabr. jimba $<$ gibba, sumportare, mentu $<$ mitto $^{4}$ ), sp. zambullir $<$ subbullire, in het Grieks $\gamma \lambda \omega \dot{\tau} \tau \alpha \varsigma>\gamma \lambda \omega \dot{v} \tau \alpha \varsigma$ enz.

Over de fonetische verklaring van dit verschijnsel heeft men z'n gedachten laten gaan: door Schuchardt ${ }^{5}$ ) „parfaitement explicable” genoemd, werd de overgang door Ružička ${ }^{6}$ ) daaraan toegeschreven, dat „tweemaal achtereen” (,zweimahl in unmittelbarer Folge”) een consonant waarvan de articulatie een relatief grote inspanning kost zou moeten worden uitgesproken, waartegenover de vervanging van de eerste door een nasaal een vergemakkelijking van articulatie betekent. Anderen ${ }^{7}$ ) zagen er een individuele uitspraakgewoonte bij een algemene tendenz in of dachten aan "Sprachfehler" ${ }^{8}$ ), weer anderen zochten de oorzaak in het accent ${ }^{9}$ ). Schuchardt merkte op : ,der die Media kennzeichnende Blählaut kann durch einen Nasal ersetzt werden, besonders wenn er gedehnt, aber auch wenn er einfach ist, ebenso die erste Hälfte der gedoppelten Tenuis, die Implosiva, wobei es sich genau genommen um die Ausfüllung einer Lücke handelt. Die Übergangen $a b b a>a m b a, a b a>a m b a, a p p a\left(a^{\prime} p a\right)>a m p a$ nehmen in ihrer Folge an Wahrscheinlichkeit ab. Ob sie überhaupt selbständig vorkommen oder etwa nur im Zusammenhang mit anderen

wörter im Arabischen, Leiden 1886, p. 136: „Die Sprache hat in die grosse Zahl der mit $n$ aufgelösten Doppelungen, die ursprüngliches $n$ enthielten, auch schliesslich solche Doppelungen gezogen die urprünglich kein $n$ enthielten"; Zimmern, Zs. f. Assyriologie 5, p. 392 vlg.

1) Zie R. Ružička, Kons. Dissim. in den Sem. Sprachen, Beiträge z. Assyriol. u. Sem. Sprachw. Leipzig 1909, p. 109-119.

2) Zimmern, t.a.p.

3) G. Meyer, in Indog. Forsch. 4 (1894), p. 330 vlg.; zie ook boven.

4) Vgl. ook Meyer-Lübke, in Grundriß der roman. Phil. I, p. 534, § 85.

5) Schuchardt, Romania 17 (1888), p. 419.

6) Ružička, o.c., p. 118.

7) W. Schulze, Kuhn's Zs. 33, p. 385

8) Zo bv, Foerster, t.a.p.

9) Zie bv. Salverda de Grave, Hand. 2e Nederl. Philologen-Congres, p. 90. 
Antrieben zur Nasalierung das kann erst die Untersuchung der einzelnen Fälle zeigen" ${ }^{1}$ ). Ook hij wijst o.a. op voorbeelden uit N.Griekse dialekten: tsakon. šinda $<€ \iota \delta \delta \alpha<\oint i \zeta \alpha^{2}$ ), en uit Italiaanse dialekten: tessin. $n z$ i.p.v. (d)d $\check{z}$, bv. ganža, tgr. gaggia ${ }^{3}$ ). Hiernaast zou men opmerkingen van Adriani over het Mentawei ${ }^{4}$ ) kunnen leggen: in het Zuidelijke hoofddialekt is de gepraenasaleerde $p$ zo goed als afwezig : sinimpu ,,afgehakt”: tippu ,afhakken”, lapi ,hoofdhaar": Noord. lampi; de gepraenasaleerde $b$ is niet zo zeldzaam: $s a b b a$,castreren”; sinamba, $o(m) b e$,kapmes”; in vele gevallen staat $b b$ naast $m b$. Ook Graur ${ }^{5}$ ) is ten aanzien van het Latijn tot de conclusie gekomen, dat er verband tussen de „consonnes géminées” en de nasaalverbindingen bestaat, en wel zo, dat ,la nasalisation a remplacé la gémination". Les sonores gém. étaient très malaisées à employer et les exemples en sont très rares. On pouvait s'en débarrasser au moyen de la nasale, qui offrait les mêmes avantages d'expressivité". Vaak, en zeker in het Semietisch, dat nasaalverbindingen alleen schijnt te kennen als remplaçant van consonantengeminatie, is dissimilatie wel de meest aannemelijke verklaring voor hun optreden. Ook Schwyzer ${ }^{6}$ ) heeft onlangs Griekse voorbeelden als

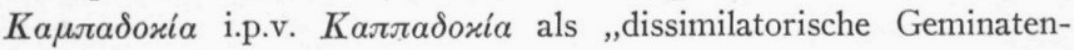
auflösung" opgevat, waarbij hij ook de bekende overgang van dentaal + dentaal in het Grieks tot $-\sigma \tau$ - als parallel beschouwde; zoals reeds vermeld, vindt men op Indonesisch gebied ook een ,,epenthetische” 's, en wel, Van der Tuuk merkte het al op, voor $t$ in het Toba-Bataks. $\mathrm{Er}$ ware een onderzoek in te stellen naar de herkomst van deze stverbindingen uit $-t t$-. Op Indo-Arisch gebied heeft men te doen met ,a tendency to pronounce words with the velum incompletely raised, which results in the vowel becoming nasalized" ${ }^{7}$ ); er zijn zeer talrijke voorbeelden van, reeds uit vroege tijd. Hierbij verdient opmerking, dat daar waar consonantverbindingen vereenvoudigd worden niet steeds dubbele consonant of gerekte vocaal optreedt, maar ook zeer vaak een korte „Nasalvocal” ${ }^{8}$ ) : zo staat tegenover skt. darśana- ,het

1) Schuchardt, Zum Nasaleinschub, Zs. f. Roman. Phil. 35 (1911), p. 72.

2) Ibidem, p. 87

3) Ibidem, p. 91.

4) Adriani, Spraakk. schets der Mentawai- eil., Bijdr. Kon. Inst. 84, p. 17 vlg.

5) Graur, o.c., p. 97.

6) Ed. Schwyzer, Kuhn's Zeitschrift, 61, p. 222 vlgg.

7) R. L. Turner, o.c., p. 344.

8) R. Pischel, Grammatik der Prãkrit-Sprachen, § 74; Grierson, JRAS. 1922, p. 381 vlgg. 
zien” in verscheiden Prākrits dampana-, tgr. skt. sparśa- ,het aanraken”: phamsa-, tgr. aśva- „paard”: amsa- enz. „The nasalization... is associated... with the simplification of ... conjunct consonants". Curieus zijn gevallen als skt. mārjāra- „(wilde) kat” : mah. mamijara-, śaur. majjāra-.

We staan dus voor de volgende vragen: valt ook op IN. terrein aan te tonen, dat onder dezelfde (en wel expressieve etc.) tendenzen geminatie en nasalering ontstaan en ten tweede valt er in bepaalde gevallen ontstaan van de nasalering uit geminaten (waarop H. Kern reeds voor een Tagalog woord eens zinspeelde ${ }^{1}$ )) te bewijzen? Daar voldoende onderzoekingen omtrent lange (gerekte) en dubbele medeklinkers ${ }^{2}$ ) in IN. talen ontbreken en mij evenmin voldoende gegevens over emfatische uitspraak etc. ter beschikking staan, kan ik deze vragen niet beantwoorden, en moet ik mij tot enkele opmerkingen beperken.

Onder de leenwoorden zou men aan skt. ojav. sajjana $>$ njav. sarjana en derg. denken.

Een gunstig object voor een onderzoek ter plaatse lijkt mij het Madoerees te zijn. Volgens Kiliaan ${ }^{3}$ ) is daar ,onder verdubbeling van een medeklinker (geminatie) (te) verstaan zijn uitspraak èn als sluitèn als beginletter" (bedoeld dus wel als implosiva + explosiva); vaak echter, voegt hij er aan toe, wordt een consonant midden in het woord zeer gerekt gesproken; er zijn gevallen van nasalering ${ }^{4}$ ), en van een

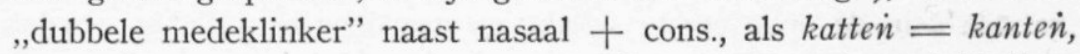
waar Kiliaan de neusklank oorspronkelijker acht dan de verdubbeling. Dit laatste is in het Toba-Bataks, zoals uit het schrift, dat nog nas. + cons. heeft, duidelijk blijkt, het geval: gattun, geschr. gantuin, zo ook in het Aboeng ${ }^{5}$ ), Boeginees, e.a. „Soms kan de verdubbeling uit assimilatie worden verklaard, wanneer er nl. een gepraenasaleerde of een gedissimileerde vorm naast staat: sabba „castreert” : sinamba „gecastreerde", zegt Adriani over het Mentawei ${ }^{6}$ ), hij voegt er interessante voorbeelden aan toe: buï nutippu arigi, ta' iaili sinimpu „hak de paal niet af, het afgehakte stuk is niet toereikend”. Een grondig onderzoek ter plaatse zou ook hier wellicht iets kunnen op-

1) Zie boven, p. 181 .

2) Zie ook Remarks, p. 184.

3) Kiliaan, Madoereesche Spraakkunst, I, p. 39, § 38.

4) Zie boven.

5) Van der Tuuk, Brieven over het Lampongsch, TBG. 19 (1870), p. 372; vgl. TBG. 18 , p. 129 vlg.

6) Adriani, Bijdr. Kon. Inst. 84, p. 27. 
leveren. Een overgang nas. + cons. $>$ dubbele cons., die in de Indische archipel voorkomt ${ }^{1}$ ), behoeft in een zelfde taalgebied een tegengesteide tendenz niet uit te sluiten. Een dergelijke overgang kan, dialektisch of in zekere taalkringen tot stand komend en als „niet correct" aangevoeld, zelfs als reactieverschijnsel langs de weg der zogenaamde inverse analogie, de tegengestelde tendenz in de hand werken ${ }^{2}$ ).

Wat de ,verdubbeling” betreft, deze vinden we in meer dan een taal speciaal na de $\breve{e}$. „Wenn auf $\breve{e}$ ein einfacher dauerlaut folgt ( $s$, nasal oder liquida, also z.B. pěsan, sěnain, gělap, běras), so wird bei gedehnter Aussprache dieser Dauerlaut verlängert, nicht der Vokal", aldus Wulff over het Maleis van Pérak ${ }^{3}$ ). Vangt in het Lampong ${ }^{4}$ ) de laatste lettergreep van een tweesyllabig woord met een lipklank aan, dan klinkt een voorafgaande $\breve{e}$ zeer vaak als $u^{5}$ ), terwijl de volgende medeklinker, ,zoo er reeds geen neusklank voor staat”, verdubbeld wordt: puppan $=$ pĕpan, mummis $=$ mĕmis. Ook hier zou een nader onderzoek dienstig zijn. In het Boeginees en Madoerees geldt de „Pěpět-wet” ${ }^{6}$ ) : „Een op een $\breve{e}$ volgende consonant wordt verdubbeld": mal. e.a. tĕbu : boeg. těbbu, ojav. etc. těnun : mad. těnnon. Ook in de Philippijnen, bv. in het Iloko en Ibanag, is deze verdubbeling regel. In het Makassaars is met of na de verdubbeling overgang van $\breve{e}>a$ opgetreden ${ }^{7}$ ). Vermoedelijk is samengaan van $\breve{e}$ en nasalering te verklaren als reactieverschijnsel tegen het verdwijnen van de $\breve{e}$ in de open eerste syllabe en daardoor eensyllabig worden

1) Zie Brandstetter, Lauterscheinungen, $\S 86$, IV.

2) Zie ook boven, p. 170 .

3) Wulff, in Acta Orientalia 4, p. 296.

4) Volgens Van der Tuuk, TBG. 18, p. 136.

5) D.i. nederl. oe.

6) Brandstetter, Sprachvergleichendes Charakterbild (1911), p. 17, § 44 II.

$\left.{ }^{7}\right)$ Door Brandstetter Gemeinindonesisch und Urindonesisch (BrandstetterBlagden, Essay II), § 24, wordt deze klankregel, naar het mij wil voorkomen, niet correct geformuleerd: „de $\breve{e}$ is in sommige IN. talen in een andere klank overgegaan..., doch heeft soms sporen van zijn vroeger bestaan achtergelaten. In het Mak. $\check{e}>a$; hier zijn dus twee etymologisch verschillende $a$ 's; $a \sim$ elders, $a \sim \breve{e}$, doch de tweede ,causes certain consonants which follow it to be doubled". De uitspraak van beide $a$ 's is (blijkens Matthes, Mak. Spraakk. § 30) eender; hieruit en uit de Pěpět-wet in andere IN. talen, speciaal het naverwante Boeginees volgt, dat niet de $a<\breve{e}$, maar de $\breve{e}$ de verdubbeling te weeg bracht. Ook het betoog van Conant, The Pěpĕt-law in Philippine Languages, in Anthropos 7 (1912), p. 920 vlgg., ten aanzien van iloko bagás etc. schijnt mij onjuiste formuleringen op dit punt te bevatten: hij laat zowel de cons. verdubbeld zijn na $\breve{e}$ en tevens $\breve{e}>a$ vóór enkele cons., wat elkaar uitsluit. 
van het woord. De frequentie van de nasalering in verband met voorafgaande vocaal etc. zou nagegaan kunnen worden.

Er zijn talen, waarin de combinatie nasaal + occlusief in een woord verloren gaat. Het Sawu, dat slechts open lettergrepen kent, heeft uit het Maleis en event. andere talen overgenomen woorden met $-n d-$ etc. zonder nasaal: deda $<$ denda, jabata $<$ jambatan, hedawa $<$ sendawa, madoro $<$ mandur, tita $<$ tinta etc. ,De uitspraak van 't Aboeng komt treffend overeen met die van 't Toba in 't niet uitspreken van neusklanken vóór scherpe medeklinkers, terwijl de daarop onmiddellijk volgende medeklinker verdubbeld wordt uitgesproken”: suppah ,eed etc.” : sumpah $^{1}$ ). De Zuidelijke Niassische dialekten hebben , de gewoonte om van $n d, m b$ in het midden van een woord en niet uitsluitend daar, de neusklank te laten vallen" ${ }^{2}$ ). In het Rotinees kunnen geen twee medeklinkers na elkaar in dezelfde lettergreep voorkomen, bij leenwoorden treden eventueel veranderingen op: palasèn $<$ ned. present; ook de neusklank verdwijnt in gevallen als tèpok $<$ mal. (port.) tempo $(h)$; maar ṅgame $<$ mal. gambir, tèmok $<$ mal. tembok ${ }^{3}$ ). „Das Ur-Ambon hat die Nasalverbindungen des $\mathrm{M}\left(\mathrm{al}\right.$.) $\mathrm{P}\left(\mathrm{ol}\right.$.) zu oralen Verschlußlaute reduziert" ${ }^{4}$ ), enz. enz. Elders gaat in zo'n geval de occlusief verloren: rot. ígeño „, heen en weer schommelen" < gengo (mak. etc.); kulawi tonu "hoorn" $<$ oerind. tanduk, aboengs lamp. pĕnazwa $<$ paingazwa ${ }^{5}$ ); atj. pinah $<$ pindah $^{6}$ ) (zie beneden). Weer elders vindt men overgang van nasaal in nasaal + consonant: mak. damaras ,fakkel, lamp" $>$ bar. ndambara. Er zou nog meer te noemen zijn, waaruit zou blijken, dat de nasaalverbindingen verschillende lotgevallen kunnen hebben, uit de nauwkeurige studie waarvan zich waarschijnlijk wel een en ander zal laten opmaken dat voor het hier behandelde van nut kan zijn.

Hoewel we over de werkelijke waarde die het schriftbeeld $\dot{n} g, n d$, $m p$ etc. vertegenwoordigt over onvolledige gegevens beschikken, blijkt toch wel genoegzaam, dat niet alle IN. talen geheel dezelfde uitspraak hebben ${ }^{\tau}$ ), en de schriftelijke weergave in sommige talen (Atjehs,

1) Van der Tuuk, Brieven Lampongs, TBG. 19 (1870), p. 372.

2) A. Lafeber, Verg. Klankleer van het Niasisch I, p. 153.

3) Vgl. verder bv. ook Esser, Klank- en vormleer van het Morisch, p. 6 over -ns-; Onvlee, Soemb. Vertellingen, p. XII vlg., met literatuur.

4) E. Stresemann, Die Lauterscheinungen in den Ambon. Spr., p. 6.

5) Van der Tuuk, Brieven Lampongs, TBG. 19 (1870), p. 372.

6) Van Langen, Handl. voor de beoef. v. d. Atj. Taal, § 23.

7) $\mathrm{Zie}$ bv. de nu reeds bijna een halve eeuw oude, doch voor hun tijd belangrijke opmerkingen van Snouck Hurgronje, Studieën over Atj. klank-' en schriftleer TBG. 1893 , p. 410; voorts Adriani, Spraakkunst der Bare'e-taal,

D1. 101. 
Makassaars, Bare'e bv. ; in Javaanse handschriften wordt de praenasalering menigmaal niet geschreven) doet wel zien, dat daar $m b$ en $b$ etc. als niet zeer verschillend worden gevoeld, anderzijds (afzonderlijke tekens voor $m b$ en $n d$ in het Karo Bataks), dat de nasaalverbinding als iets anders dan een combinatie van "afzonderlijke” nasaal + cons. wordt opgevat. Dat $m b: m$, nd $: n$ etc. ook dicht bijeen kunnen liggen is in het algemeen bekend en daarop wijzen ook wisselingen als tbat. singar: sinar enz. ${ }^{1}$ ), van atj. tömah, verbum naast tömbah subst. $=$ mal. sěmbah ${ }^{2}$ ), de Tontemboanse dialektverschillen als $p a^{\prime}$ des : pa'ndes ,kwellen” ${ }^{3}$ ), Rottinese overgangen als $n d>n, \dot{n} g>\dot{n}$ etc. ${ }^{4}$ ). En het bestaan van dergelijke overgangen ook in woorden waarin de omstandigheden, waarop Brandstetter, Adriani, Jonker hun verklaringspogingen baseren ${ }^{5}$ ), niet optreden is een argument voor de stelling, dat het ,,vernasaleren” van occlusivae nog andere oorzaken moet hebben. In meer dan een taal wordt in de "combinaties" of ,verbindingen" $\dot{n} g, \tilde{n} j, n d, m b$ het occlusieve element zeer zwak uitgesproken, zelfs zo zwak, dat het nauwelijks waar te nemen is ${ }^{6}$ ), bv. in het Gajo, met Maanjan, Madoerees, Soendaas; in het Atjehs ,is de samensmelting soms zo innig, dat het tweede deel der combinatie in het eerste opgaat en dus een nasaal overblijft" " $)$. Weer elders, bv. in Soendaas en Rottinees, wordt vooral de gutturale media slechts met een nasale voorslag gesproken ${ }^{8}$ ), ook in overgenomen woorden: mal. gadii $>$ rott. ingadi, ned. glas $>$ rott. ngalás; het West-Soembaas heeft daarbij de neiging on anlautende nasale voorslagen af te werpen $\left.{ }^{9}\right)$. In het Soendaas valt naast de

p. 42; Jonker, Bimaneesche Spraakkunst, p. 15; Onvlee, Soembasche vertellingen, p. VIII vlg.; Schwarz-Adriani, o.c., p. 11; Dempwolff, Zs. f. Eing. Spr. 15, p. 20 ; Wulff, in A.O. 4, p. 269.

1) Vele voorbeelden bij Van der Tuuk, Tobasche Spraakkunst, p. 69.

2) Zie ook Snouck Hurgronje, o.c., p. 7. Voorts bv. Blake, A Grammar of the Tagalog Language, p. 7.

3) Zie Schwarz-Adriani, o.c., p. 36 .

4) Jonker, Bijdr. tot de kennis der Rottin. tongvallen, Bijdr. Kon. Inst. 68, p. 529 .

5) Zie boven, pp. 143 vlgg.; Onvlee, o.c., p. XVI vlg.

6) Zie bv. Brandstetter, Die Lauterscheinungen (Brandstetter-Blagden, Essay IV), § 47; Hazeu, Gajōsch-Ned. Wdb., p. VIII; Sundermann, Der Dialekt der „Olon Maanjan” (Dajak), Bijdr. Kon. Inst. 67, p. 204; Kiliaan, Mad. Spraakk. p. $28, \S 24$.

$\left.{ }^{7}\right)$ Snouck Hurgronje, o.c., p. 370 .

s) Jonker, Rottin. Spr. p. 4; 51; 73; vgl. ook Onvlee, o.c., p. XVII ; Jonker, Bim. Spr. p. 76.

9) Onvlee, o.c., p. 18. 
sterke tendenz tot praenasalering van mediae de tegengestelde tendenz bij tenues op: mal. intan > ita; naast jav. lĕmpit : lăpitu ,vouwen”; men vindt ook gepraenasaleerde media tegenover elders een tenuis: soemb. ndoun : saw. tou $^{\mathbf{1}}$ ). Doch elders vindt men weer blijken van tegengestelde tendenzen: soend. tincak ,'t neerzetten van de voet": mal. $t i(n) j a k$, jav. tindak, tag. tindak, ngday. tinjak etc. Intussen gaf Wulff $^{2}$ ) als zijn mening te kennen: „Holländische autoren geben zuweilen an, sie (nl. de mediae) klängen, als gehe ein nasal voran; für den hiesigen dialekt trifft das nicht zu, und es wird wohl auch nur eine täuschung des an den schwächeren stimmtön gewöhnten Germanen sein". Waarbij men niet mag vergeten, dat hier niet allen wier moedertaal een Germaanse is onder dezelfde omstandigheden verkeren. Elders weer klinkt de $n$ van vreemde woorden den Indonesiër als $n d$, althans hij geeft de klank zo weer ${ }^{3}$ ). In vreemde woorden tracht men vaak klanken die de eigen taal mist te benaderen door ze als een klankverbinding te interpreteren ${ }^{4}$ ). Weer in andere talen zal de samenhang tussen nasalering en hamzering, alsook tussen deze verschijnselen en tendenz tot wijziging van de volgende klank moeten worden nagegaan ${ }^{5}$ ).

Uit deze en dergelijke gegevens blijkt voldoende, dat, wat we ook ter verklaring van de nasaleringsverschijnselen in het midden mogen brengen, een zo breed en diep mogelijke vaststelling van de fonetische omstandigheden een vereiste blijft. Maar het constateren daarvan alleen levert ook weer geen complete verklaring, zoals wellicht Adriani aanvankelijk meende: van de nasalering van lettergrepen zijn vele voorbeelden in de IN. talen, ,het verschijnsel is niets anders dan 't los sluiten van een open lettergreep" ${ }^{6}$ ).

Al zou ik invloed van een nasaal op andere plaats in het woord, de hypothesen van Adriani en Dempwolff als universele verklaring bestrijdende, niet geheel en al willen uitsluiten : het is bv. toch merkwaardig, dat in het Billiton-Maleis ${ }^{\top}$ ) mansih $=$ masih, munsuh $=$

1) „Die Kleinasiaten welche keine reine Media aussprechen konnten, sprachen entweder Tenuis oder Nasal und Media, welch letzteres auch die meisten heutigen Griechen thun", Thumb, Byzant. Zs. 9 (1900), p. 409.

2) Wulff, o.c.

3) Van der Tuuk, Tobasche Spraakkunst, p. 69.

4) Vgl. N. S. Trubetzkoy, Grundzüge der Phonologie (1939), p. 58.

5) Zie bv. Schwarz-Adriani, o.c., p. 10.

6) Adriani, Sangireesche Spraakkunst (1893), p. 29.

7) Vorderman, Bijdrage tot de kennis van het Billiton Maleis, TBG. 34, p. 373 vlgg. 


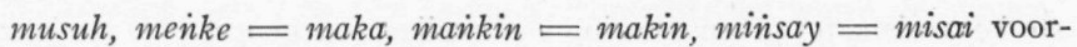
komen, waarnaast echter ook ěmpama $=$ upama, sĕlěnsei $=$ sělěsai; er laten zich echter op grond van zo'n klein woordenlijstje geen conclusies trekken.

De conclusie van bovenstaande beschouwingen kan kort, moet in hoofdzaak echter negatief zijn: de tot nu toe gegeven theorieën omtrent het ontstaan van de inwendige nasalering lijken mij aan bedenkingen onderhevig; er is een opvallend parallelisme met de inwendige liquida $(r)$; er zijn zodanige punten van overeenkomst met de ,epenthesis-verschijnselen" van nasaal en liquida in andere talen, met de zg. spontane nasalering etc., dat, hoewel de verklaringen van Adriani, Brandstetter en Dempwolff in een aantal gevallen het juiste kunnen hebben getroffen, in verscheidene andere gevallen de waarschijnlijkheid er voor pleit, ook op Indonesisch gebied deze ,epenthesis” van nasaal en liquida aan te nemen; uit de aard der zaak hebben ook hier analogie, blending etc. hun gewone rol gespeeld; de oorsprong van het verschijnsel (dissimilatie etc. etc.) zal nog onderzocht dienen te worden. En al zullen we ons ook hier er bij moeten neerleggen, dat we slechts een deel van de sluier zullen kunnen oplichten, een nader onderzoek ter plaatse over de hierboven genoemde en andere punten zal m.i. nodig zijn voor er veel meer over te zeggen zal zijn.

Tot nog toe citeerde ik ter vergelijking bij de Indonesische nasalering alleen IndoGerm. en Semietische voorbeelden. Hier wijs ik er nog op dat nasaleringsverschijnselen ook in andere taalfamilies aan te treffen zijn. In het Ewe ${ }^{1}$ ) en wel in het „Innere des westlichen Ewesprachgebietes" ${ }^{2}$ ) wordt vaak ,zwischen die letzte und vorletzte Silbe ein [homorgane, J. G.] nasaler Konsonant eingeschoben". In een aantal der door Westermann genoemde voorbeelden heeft het Anilo-dialekt in de laatste syllabe een nasale vocaal, het „Innere des w. E.” inwendige nasalering maar geen nasale slotvocaal, volgens W. waarschijnlijk de jongere toestand, bv. akagã ,gier" : akanga. Maar er zijn ook verscheidene gevallen, waar het Arilo geen genasaleerde slotvocaal heeft: aḍaka ,kist” : adạika.

Over een tweetal punten tenslotte, die men wanneer men het nasaleringsverschijnsel in de Indonesische talen in den brede zou willen bestuderen, niet buiten beschouwing zal kunnen laten, spreek ik mijn mening, die slechts op het mij bekende, onvolledige materiaal kan berusten, niet uit. Vooreerst is, voorzoover ik weet, door de meer-

1) D. Westermann, Grammatik der Ewe-Sprache, Berlin 1907, § 48.

2) Ook elders, zie Westermann, t.a.p., waar literatuur. 
malen genoemde geleerden bij het opstellen hunner hypothesen ter verklaring van het verschijnsel der inwendige nasalering niet in het geding gebracht de praenasalering aan het begin van het tweede deel van composita en bij adverbia, waarover wij bv. uit de werken van Adriani en Esser voor de talen van Celebes zijn ingelicht. Een bespreking hiervan zou buiten mijn onderwerp liggen: maar toch zou men, indien men alleen zou afgaan op wat Esser er in zijn Morigrammatika van zegt ${ }^{1}$ ), geneigd kunnen zijn deze nasalering in nauw verband te brengen met de inwendige nasalering.

In het Mori kan, zoals Esser opmerkt, het bepalende adjectief als tweede lid van een samenstelling òf onveranderd blijven òf zonder praefix staan ò wel het kan aan het begin gepraenasaleerd worden; deze drie gevallen vertegenwoordigen een climax van telkens nauwere verbinding tussen beide delen: zo vindt men naast one pute ,witte kiezel" manu mpute ,witte kip"; de reden van het verschil is echter niet duidelijk. Ook bij de determinatieve samenstelling van twee substantiva met possessieve verhouding komt de praenasalering vaak, doch ook wel eens niet, voor : zeiwi ntahi, ,zeestrand”, maar taike piso „,handvat van een mes”, taku puri ,bil”. Bovendien is er hier dialektverschil: het Boven-Mori mist vaker de praenasalering dan de taal van Tinompo: b.m. lewe kau ,boomblad”" tegenover t. lewe íkeu. Bij andere determinatieve samenstellingen van substantiva is deze praenasalering uitzondering; er zijn gevallen, waarin men het wel doet „eenvoudig omdat men in samenstellingen nu eenmaal graag praenasaleert” ${ }^{2}$ ). Ook bij de ,samenstelling van een adjectief of verbum met een adjectief, waarbij dit laatste als bijwoordelijke bepaling fungeert" ${ }^{3}$ ) treedt praenasalering bij sommige beginconsonanten, hoewel niet steeds, op. - Hoewel ze dus niet in alle gevallen voorkomt, wijst deze nasalering op samenstelling etc. Alleen afgaande op deze gegevens zou men uit haar aanwezigheid kunnen opmaken, dat de beide delen als nauw verbonden gevoeld worden: een eigenaardigheid uit het inwendige van een woord schijnt, om het zo uit te drukken, op dat van een combinatie overgedragen. De vele uitzonderingen, de afwezigheid van regelmaat zou er dan op kunnen wijzen, dat men hier met een verschijnsel te maken heeft dat op een aan dat der inwendige nasalering analoge wijze beoordeeld moet worden.

In andere, naverwante, talen vindt men deze nasalering echter

1) Esser, o.c., pp. 82 vlgg.

2) Esser, o.c., p. 86.

3) Vgl. Esser, o.c., p. 93, § 141. 
eveneens, en in de werken van Adriani ${ }^{1}$ ) wordt er onder de benaming "nasaal tussenzetsel” herhaaldelijk melding van gemaakt. Soms komen er naast deze nasalering nog andere methoden om dezelfde verhouding uit te drukken voor: het hierna te noemen $n u$, juxtapositie zonder meer, possessief suffix aan het eerste woord. Elders is, zoals Adriani ${ }^{2}$ ) het uitdrukt, ,het lidwoord der woorden die in den genitief staan” $n u$ : loin. pala nu lima ,handpalm”, weer elders ,geschiedt de genitief-constructie zonder tussenzetsel" ${ }^{3}$ ): mamoedjoe bulu mata ,wenkbrauw”. Waar nu de nasalering voorkomt, beschouwt Adriani deze als uit $n u$ ontstaan: ,,$n u$ afgekort tot een enkele nasaal, die dan den beginner van het geregeerde woord prenasaleert" ${ }^{4}$ ); zo heeft het Bare'e rena íkaju ,boomvrucht" tegen het Loinang bua nu kau; ,afkorting" vindt men ook in het Petapa, waar in plaats van het lidwoord $n u$ soms de aanvangsnasalering van het tweede deel van een possessieve verbinding voorkomt: gigis nu tasi "oever der zee" tegenover tazen mpaain ,kuit van het been" ${ }^{5}$ ). De derde en vierde wijze van uitdrukking der bezitsverhouding etc., nl. die door eenvoudige juxtapositie (bv. mekongka iwoi mata ,traan”) en die met behulp van anhechting van het pers. voornaamwoord van de $3 \mathrm{e}$ persoon in suffixvorm achter het bepaalde woord (bv. boengkoe wuano keu ,boomvrucht”) zijn eveneens verbreid in de talen van Celebes. Waar wij nu drie irreductibele constructies ter uitdrukking van deze verhouding vinden (die met juxtapositie, die met pron. suff., die met $n u$ ), kan a priori ook de vierde geacht worden van de andere onafhankelijk te zijn, en het verdient daarom wel opmerking, dat volgens Adriani zelf in het Bare'e syncope alleen voorkomt bij klinkers die tussen een voorafgaande nasaal en een volgende nasaleerbare consonant $\left.\operatorname{staan}^{6}\right)$; alleen de gevallen met $n u$ vallen er, blijkens de gegeven toelichting, onder. Bovendien blijkt ook uit wat Adriani in ander verband zegt $^{7}$ ), dat hij de herkomst van deze praenasalering

1) Bv. Adriani en Kruyt, De Bare'e-sprekende Toradja's van Midden-Celebes, III, pp. 88 (Boengkoe), 120 (Napoe), 131 (Bada en Besoa), 152 (Mamoedjoe), 180 (Petapa); Adriani, Spraakkunst der Bare'e-taal, §§ 13; 14; 57; 265 vlgg.

$\left.{ }^{2}\right)$ Adriani en Kruyt, De Bare'e-sprekende Toradja's van Midden-Celebes, III, p. 85 .

3) T.a.p. III, p. 152 ; vgl. p. 164 vlg.

4) T.a.p. III, p. 88 . Dempwolff, Zs. f. Eing. Spr. 15, p. 234 is van mening, dat de nasaalverbinding ,durch Verschmelzung mit der Ligation u.an. (uraustron.) mi" ontstaan is.

5) T.a.p., III, p. 180 .

6) Adriani, Spraakkunst der Bare'e-taal, p. 49.

7) Ibidem, p. 48; vgl. ook p. 429 midden. 
uit een gesyncopeerd $n u$ slechts als een mogelijkheid geeft: ,sommige geprenasaleerde adjectief- of werkwoordstammen, die met substantieven tot samenstellingen verbonden worden, maken den indruk van intensieve vormen; het komt mij intusschen juister voor ze op te vatten als gesyncopeerde vormen, hetzij als bijv. naamwoorden of deelwoorden die op de gewone wijze met $m a$-, mo- of $m \breve{e}$ - zijn gevormd, maar den klinker van het prefix hebben uitgestooten, waardoor de $m$ tot prenasaleering van den stam is geworden, hetzij als een met $m u$ gelijk te stellen prenasaleering bevattende...”. $\mathrm{Nu}$ is weliswaar in het dialekt van Ampana, waar men vlug spreekt, deze syncope zeer gewoon, maar daar is ze niet beperkt tot woorden die met nasaal aanvangen; men zegt er bv. ook psuli, ,huis” i.p.v. pasuli. Maar wanneer Adriani een uitdrukking als bar. mbaa-mbo'o ,roodkop ('n vogel)" als volgt verklaart: ,deze uitdrukking kan zijn gesyncopeerd uit... maz'aa wo'o ( $m b o^{\prime} o$ is alliteratie met mbaa, of omgekeerd) of anders een explicatieve genitief, dus uit $n u$ wo', en dus drie mogelijkheden ter keuze geeft, dan makt hij de verdediging van zijn stelling niet sterker.

Ook met wat hij verder ten aanzien van de afhankelijkheid van de syncope van het accent opmerkt ${ }^{\mathbf{1}}$ ) schijnt hij $\mathrm{m}$.i. zijn betoog niet te versterken : terwijl ook in het Ampana „,de scherpe klemtoon” hierbij van invloed is: „het is voornamelijk de vocaal der lichtste lettergreep (die welke vóór de beklemtoonde staat) die uitgeworpen wordt", hecht zich $m u$ ook in het Bare'e proclitisch aan het woord waarbij het behoort, maar ,daar deze syncope grammatikale waarde heeft, wordt zij niet alleen vlak vóór den klemtoon toegepast, maar ook daar waar het op $n u$ volgende woord drie- of meerlettergrepig is", bv. ira ikayuku ,kokosblad”. Enerzijds zou de syncopering o.a. afhankelijk zijn van het onmiddellijk volgende accent ${ }^{2}$ ), anderzijds bestaat ook $n u$ zelfs vlak voor het accent ${ }^{3}$ ). Bovendien is in de ,possessief-verding" $n u$ vaak niet aanwezig: Adriani neemt dan aan ${ }^{4}$ ), dat het is weggelaten; de praenasalering blijft echter nooit achterwege. Wat nu de talen, zoals het Mori, betreft, waarin $n u$ niet voorkomt en wel de praenasalering, het lijkt mij te ver gaan om daar zonder meer als

1) O.c., p. 49 .

2) Men merke op, dat het accent in het Bare'e geen nadruksklemtoon is!; $\S 4$ betoogt Adriani dat anders dan in het Nederlands, waar de nadruksklemtoon heerst "gewoonlijk ten koste der voorafgaande en volgende lettergrepen", in het Bare'e ,de niet geklemtoonde lettergrepen niet worden verwaarloosd".

3) Zie o.c., § 265.

4) O.c., p. 420 . 
zeker aan te nemen - een indruk die men uit het genoemde werk van Adriani en Kruyt bekomt - , dat de laatste daar uit het eerste is ontstaan; m.i. terecht laat Esser dit punt onbesproken. Naar mijn mening dient er naar deze nasalering en wat er mee samenhangt (inclusief de Tagalog etc. ,ligatuur”) nog eens een grondig onderzoek te worden ingesteld.

Hier herinner ik in het voorbijgaan nog aan het veel gebruikte $i$ in het Bolaang-Mongondow ${ }^{1}$ ), dat (om Dunnebier te citeren) ,in hoofdzaak aanwijzende kracht [heeft], vaak weer te geven [is] met ons bepalend lidwoord, maar ook betr. vnwd., genitiefteeken enz. [is]"; wanneer dit $i$ voor een pers. vnwd. komt, wordt het genasaleerd: in-kita, in-kami; komt het voor bij telwoorden, ter vorming van rangtelwoorden van cardinalia, dan treedt ook, waar dit mogelijk is, de nasaal op: indua ,de tweede” enz. Ook zij herinnerd aan de nasaal in nauwe verbindingen van telwoorden en bepaalde kategorieën van andere woorden: in het Boeginees bv. ${ }^{2}$ ) de uitdrukkingen voor tientallen etc., numeratieven, tijdsduur en geldswaarde-aanduidende woorden: boeg. patampulan „4 maanden” etc.

Een tweede kwestie is de reeds in het begin van dit stuk aangestipte verhouding van de $\mathrm{zg}$. inwendige nasalering en de bekende aanvangsnasalering met grammatikale functie. $\mathrm{Nu}$ - deze conclusie mag ik mij wel veroorloven - een vergaand parallelisme tussen de vormen met inwendige nasaal en die met inwendige $r$ blijkt te bestaan, dienen we in de eerste plaats op de gelijkwaardigheid van door nasaal gesloten met door liquida gesloten praefixen te wijzen ${ }^{3}$ ): in Bataks, Makassaars, Boeginees, Bisaya bv. is pa- + nasalering veelal gelijkwaardig aan $p a-+r$, in de Westelijke talen zijn $m a-+$ nasalering en $m a-+r$ vaak niet te onderscheiden etc. $\left.{ }^{4}\right)$; in de Westelijke talen heeft de praenasalering veelal de functie van de triller overgenomen" $\left.{ }^{5}\right)$; $p a-a n$-vormen met nasalering en $r$ na $p a$ - zijn in verscheiden talen gelijkwaardig enz. enz. Welke opvatting is, in de tweede plaats, waarschijnlijker: die, dat in $p a-+$ nas. en $p a-+r$ twee elementen, nl. $p a-$ en het andere deel, met elkaar vergroeid zijn $^{6}$ ), of

1) Dunnebier, Spraakkunst van het B. M., Bijdr. Kon. Inst., dl. 86, pp. 120 vlgg. (§ 245); vgl. § 237; § 229.

2) Matthes, Boegineesche Spraakkunst, § 126.

3) Vgl. hierbij R. A. Kern, De partikel $p a$ in de Indonesische talen, Bijdr. 92 (1934), p. $25 ; 26 ; 29$.

4) Ibidem p. 70 .

5) Ibidem, p. 23.

6) Brandstetter, Das Verbum, § 52; Kern, ibidem, p. 16. 
de door Fokker op de wijze van een halve eeuw geleden als volgt uitgedrukte: „Originally a mere phonetic phenomenon, originated by want of smoothness in pronunciation, both way of connecting prefix with stem seem to have independently developed to special grammatical „,caracteristics"?” ${ }^{1}$ ). Mij dunkt, indien het bovenstaande in hoofdzaak het juiste zou treffen, zou het ten gunste van Fokker's stelling pleiten. Al geef ik hiermee, zoals gezegd, geen definitieve mening te kennen. Fokker wijst ter adstructie op talen als het Soembaas, waar deze scheiding tussen nasaal- en $-r$ - praefixen nooit plaats had.

Men zou in dit verband ook op vormen als de volgende kunnen wijzen, waar de praenasalering zeker geen grammatikale functie heeft, evenmin als een zelfstandig element optreedt: geredupliceerde vormen, waarin praenasalering: per. mal. běmbarain $=$ barañ $^{2}$, pěmpětaì $=$ pětain ${ }^{2}$ ). Brandstetter maakte reeds attent op deze eigenaardigheid in verband met sang. děndila ,e. vis” bij dila ,tong” ${ }^{3}$ ), Hardeland ${ }^{4}$ ) vermeldde day. dandayu ,vlag”; vlg. voorts atj. dendayain ,hofdame” = mal. dayain, jav. sansaya ,telkens..." naast saya, waarnaast dan een geval met $l$-epenthesis als fil. negr. balbata ,jongeling” tegenover tag. bis. bata ,,jongen" ${ }^{5}$ ). Brandstetter ${ }^{6}$ ) dacht hier in de eerste plaats aan dissimilatie als oorzaak: děndila $<*$ deldila. Tegen een herkomst van de $\mathrm{zg}$. intensiteitsvormen uit nasalering zonder grammatikale waarde zou verder de omstandigheid, dat ze elders andere grammatikale waarde heeft niet behoeven te pleiten, eerder zelfs andersom: ik herinner aan de „meervoudige kracht” die ze heeft in mpampe-: mori mperenku ${ }^{2}$,met veel knobbels" ${ }^{7}$ ), aan

1) A. A. Fokker, Malay phonetics, p. 54. In dit verband roep ik de opmerkingen van Van der Tuuk (Tob. Spr., p. 126) te binnen: mar- heeft zijn sluiter te danken aan zijn plaats in de derde lettergreep van achteren vóór de meestal tweelettergrepige woorden. Vgl. jav. marmata $<$ manmatha, mal. tărmasa < tamāsjā. Het Bataks bezigt in de regel andere medeklinkers voor dit doel, 'n neusklank uppama (< umpama), een sisser rostaha, tgr. dairi rintaka etc. ,'t Bataksch heeft echter van die klankwet gebruik gemaakt om een verschil van beteekenis uit te drukken, daar de $r$ als ruischende klank zeer goed 't active symbolisch kan voorstellen. Dat verder een neusklank ook hiervoor in gebruik is gekomen, moet men aan den galm van zoo'n medeklinker toeschrijven", de nasaal „vermeerderde de verbale kracht”. Men zou - overbodig het te zeggen - een dergelijke opmerking thans anders formuleren.

2) Wulff, Acta Orientalia 4, p. 262.

3) Brandstetter, Die Reduplikation, § 41, p. 15.

4) Hardeland, o.c., p. 26.

5) Balbata steht wohl für babata, reduplicirte Form, wie z.B. auch bis. lalaki von laki", Kern, V.G., Suppl., p. 13.

6) O.c., t.a.p.

7) Esser, o.c., p. 319 , voorts p. 336 etc. 
de betekenis ,gelijkende op" in het Sangirees ${ }^{1}$ ), aan die ,korte tijd”of een weinig doen" in het Dajaks ${ }^{2}$ ). Dit alles kan op verschillende ontwikkeling tot een bepaalde woordvormende of grammatikale functie van een procédé wijzen, dat oorspronkelijk een zodanige functie niet had.

1) Adriani maakte er (Sang. Spr., p. 69) op attent, dat in het Sangirees sommige woorden een reduplicatie hebben met de klinker $\check{e}$, los gesloten, d.w.z. door nasaal gevolgd; deze woorden betekenen ,gelijkende op hetgeen het grondwoord aanduidt", ze komen veel voor bij namen van bomen, planten etc., die benoemd zijn naar een in de ogen des volks gelijksoortig voorwerp, o.a. bulaeng „goud”: běmbuḷaeng „kokos met geelachtige bladstelen” etc.; hier heeft deze "door nasaal gevolgde" reduplicatie derhalve een woordvormende functie. Vgl. ook ibidem, p. 129 vlg.; 143 vlg.

2) In het Dajaks nemen enkele „reciproque adverbia of participia”, zoals Hardeland ze noemt, i.p.v. ha- : han- of ham-als praefix aan : biran ,uitgebreid zijn" hambiran "uitgebreid"; soms is het praefix haka-, waarnaast, als het grondwoord met $k$ aanvangt, ook hakan-: kejau „ver": hakanikejau, „zich van elkaar verwijderen”, kamit „pikken” etc. (van vogels)”: hakan்kamit „elkaar pikken". Er bestaan ook curieuze reduplicata: gagar "afvallen": mangagar „afwerpen”, maniganigagar en manigaganigagar „enige (vruchten etc.) afwerpen"; bilit „omwikkeld zijn": mambilit, mambambilit, mambilimbilit, tarik ,het geworpen zijn" mantantarik, mantarintarik, etc.; deze vormen hebben alle de betekenis „een weinig, korte tijd” etc. doen etc. wat het grondwoord uitdrukt. Voorts zijn er, vooral onder de met $k$ of $t$ beginnende, grondwoorden, die naast een twee- ook een driesyllabige vorm vertonen; de langere vorm heeft dan meestal kan, tan, tan, sain als eerste syllabe; worden er van de kortere vorm afleidingen gevormd, dan wordt gewoonlijk een naam ,ingeschoven” : „nauwkeurig zien" kilik en takilik of taìkilik, afleidingen: man்kilik, maar manakilik. Hardeland, o.c., pp. $35 ; 46 ; 60$; 68 vlg.). 